


\section{Heavy Fuel Oil (HFO)}

A review of fate and behaviour of HFO spills in cold seawater, including biodegradation, environmental effects and oil spill response

Janne Fritt-Rasmussen, Susse Wegeberg, Kim Gustavson, Kristin Rist Sørheim, Per S. Daling, Kirsten Jørgensen, Ossi Tonteri and Jens Peter Holst-Andersen

TemaNord 2018:549 


\section{Heavy Fuel Oil (HFO)}

A review of fate and behaviour of HFO spills in cold seawater, including biodegradation, environmental effects and oil spill response

Janne Fritt-Rasmussen, Susse Wegeberg, Kim Gustavson, Kristin Rist Sørheim, Per S. Daling,

Kirsten Jørgensen, Ossi Tonteri and Jens Peter Holst-Andersen

ISBN 978-92-893-5850-7 (PRINT)

ISBN 978-92-893-5851-4 (PDF)

ISBN 978-92-893-5852-1 (EPUB)

http://dx.doi.org/10.6027/TN2018-549

TemaNord 2018:549

ISSN $0908-6692$

Standard: PDF/UA-1

ISO 14289-1

(C) Nordic Council of Ministers 2018

Cover photo: Unsplash.com

Print: Rosendahls

Printed in Denmark

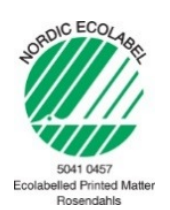

\section{Disclaimer}

This publication was funded by the Nordic Council of Ministers. However, the content does not necessarily reflect the Nordic Council of Ministers' views, opinions, attitudes or recommendations.

Rights and permissions

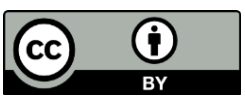

This work is made available under the Creative Commons Attribution 4.0 International license (CC BY 4.0) https://creativecommons.org/licenses/by/4.0

Translations: If you translate this work, please include the following disclaimer: This translation was not produced by the Nordic Council of Ministers and should not be construed as official. The Nordic Council of Ministers cannot be held responsible for the translation or any errors in it.

Adaptations: If you adapt this work, please include the following disclaimer along with the attribution: This is an adaptation of an original work by the Nordic Council of Ministers. Responsibility for the views and opinions expressed in the adaptation rests solely with its author(s). The views and opinions in this adaptation have not been approved by the Nordic Council of Ministers. 
Third-party content: The Nordic Council of Ministers does not necessarily own every single part of this work. The Nordic Council of Ministers cannot, therefore, guarantee that the reuse of third-party content does not infringe the copyright of the third party. If you wish to reuse any third-party content, you bear the risks associated with any such rights violations. You are responsible for determining whether there is a need to obtain permission for the use of third-party content, and if so, for obtaining the relevant permission from the copyright holder. Examples of third-party content may include, but are not limited to, tables, figures or images.

Photo rights (further permission required for reuse):

Any queries regarding rights and licences should be addressed to:

Nordic Council of Ministers/Publication Unit

Ved Stranden 18

DK-1061 Copenhagen K

Denmark

Phone +4533960200

pub@norden.org

\section{Nordic co-operation}

Nordic co-operation is one of the world's most extensive forms of regional collaboration, involving Denmark, Finland, Iceland, Norway, Sweden, and the Faroe Islands, Greenland and Åland.

Nordic co-operation has firm traditions in politics, economics and culture and plays an important role in European and international forums. The Nordic community strives for a strong Nordic Region in a strong Europe.

Nordic co-operation promotes regional interests and values in a global world. The values shared by the Nordic countries help make the region one of the most innovative and competitive in the world.

The Nordic Council of Ministers

Nordens Hus

Ved Stranden 18

DK-1061 Copenhagen K, Denmark

Tel.: +4533960200 www.norden.org

Download and order Nordic publications from www.norden.org/nordpub 



\section{Content}

Preface .7

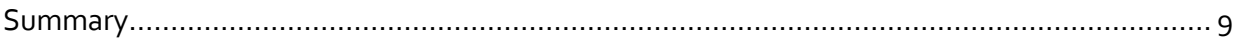

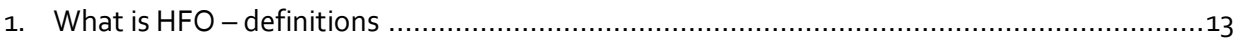

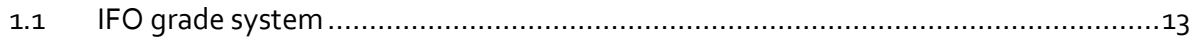

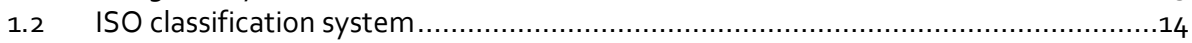

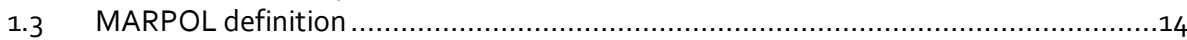

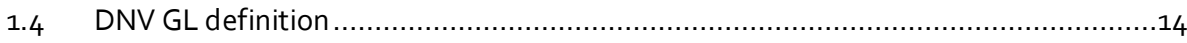

1.5 Other often used terms/definitions...........................................................

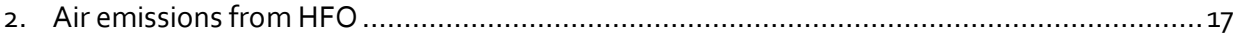

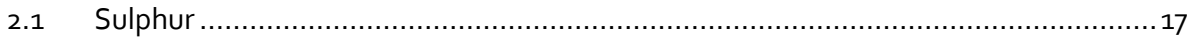

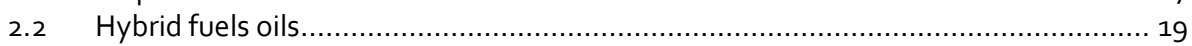

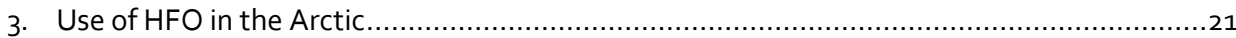

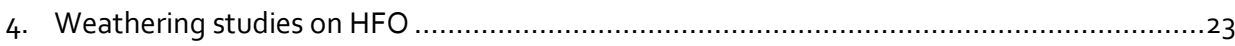

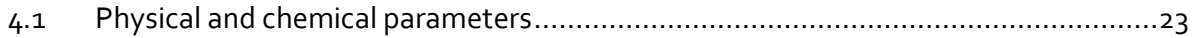

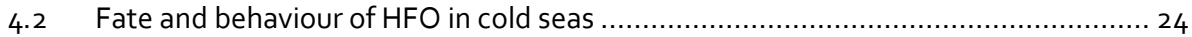

4.3 Main findings from SINTEF weathering experiments and modelling including HFO 25

4.4 Overall findings about the fate and behaviour of HFO ..................................... 31

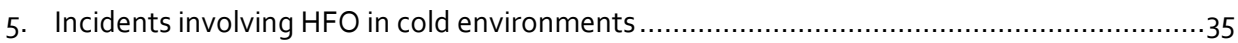

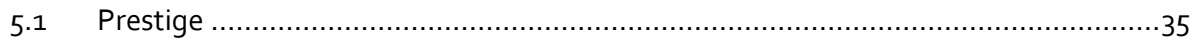

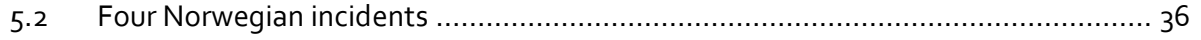

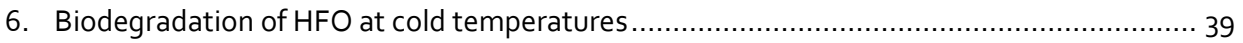

6.1 Methods used for measurement of biodegradation ....................................... 39

6.2 Methods used for microbial analyses ........................................................ 40

6.3 Overview of biodegradation ranges in different compartments ............................ 40

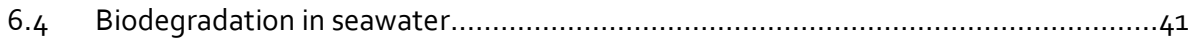

6.5 Biodegradation in the sediment compartment .............................................. 44

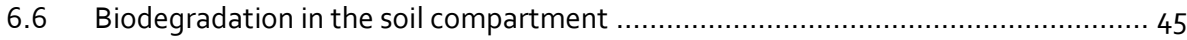

6.7 Biodegradation in the ice compartment ..................................................... 46

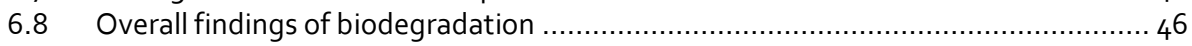

6.9 Potential for biodegradation of HFO in the marine environment ......................... 46

7. Environmental impacts from marine HFO spills..................................................... 49

7.1 Experiences from oil spills at the Norwegian coast......................................... 50

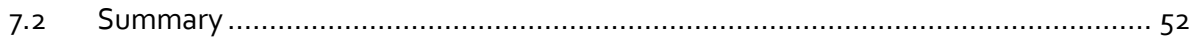

8. Possible oil spill response measures for Heavy Fuel Oil ................................................ 55

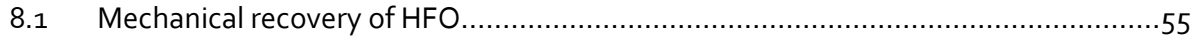

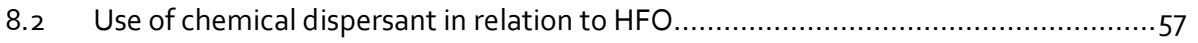

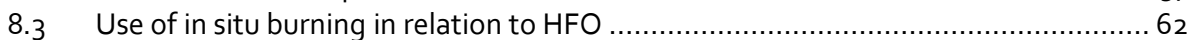

8.4 Environmental benefit or consequences of response techniques............................ 64

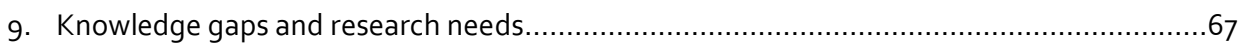

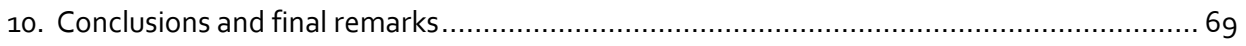

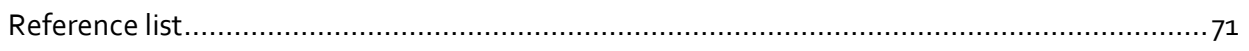

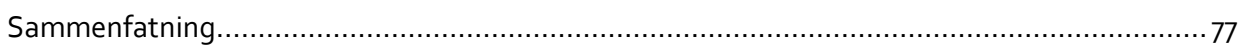


Appendix 1 - Literature search strategy for the review............................................. 81

Literature search strategy for the HFO fate and behaviour review.................................. 81

Literature search strategy for the oil biodegradation review ...................................... 82

Appendix 2 - Oil spills with HFO in cold/Arctic environment .......................................... 83

Appendix 3 - Biodegradation studies overview .......................................................... 85 


\section{Preface}

As a result of the ice melt in the Arctic Ocean new shipping routes will become available and thus shipping activities across the Artic are expected to increase. For instance, DNV GL (Den Norske Veritas) (in PAME II [2016]) has estimated that "an incident leading to an oil spill is likely to happen every second year within the Bering Sea".

Heavy Fuel Oil (HFO) consists mainly of residual products from crude oil refining processes, and as it is relatively cheaper than, for instance, lighter marine fuels it is often used as fuel in marine vessel engines (PAME II 2016). HFO and residual fuel oils may also be transported as cargo since pipelines cannot export such high viscous products.

Knowledge about the fate and behaviour of oils, including HFO, is important in order to select the most efficient countermeasures in an oil spill situation as well as in the risk assessment of possible oil spills in cold waters. Also, in relation to the Net Environmental Benefit Analysis (NEBA, also called SIMA- Spill Impact Mitigation Assessment) such knowledge is crucial to ensure the best choice of response measures to protect the environment.

This project aims to gather and strengthen the knowledge base on the fate and behaviour of HFO spills in cold seawater, including also biodegradation environmental effects and oil spill response. The report is based on existing literature and results from laboratory weathering tests of HFO performed by SINTEF. Knowledge gaps and research needs are identified and described.

New regulations on the sulphur content of ship fuels (IMO 2017) came into force in 2015 within the Sulphur Emission Control Areas (SECAs); thus, ships must use fuels with a maximum sulphur content of $0.1 \%$, and $0.5 \%$ from 2020 . This has resulted in the introduction of an increasing number of "new generation" (also called Hybrid Fuel Oils) of low sulphur marine fuel oils on the market, replacing the HFOs. Accordingly, the report includes these hybrid fuel oils, where possible.

The project was funded by The Nordic Council of Ministers - The Marine Group (HAV). The biodegradation part of the report was partly funded by the EU H2O2O project GRACE under grant number 67926620 . The report was prepared by:

- Janne Fritt-Rasmussen, Susse Wegeberg, and Kim Gustavson (Danish Centre for Environment and Energy, Aarhus University, Denmark).

- Kristin Rist Sørheim and Per S. Daling (SINTEF Materials and Chemistry, Marine Environmental Technology, Norway).

- Kirsten Jørgensen and Ossi Tonteri (SYKE, Marine Research Centre Finnish environment institute, Finland).

- Jens Peter Holst-Andersen (Danish Ministry of Defence, Denmark). 


\section{Summary}

As a result of the ice melt in the Arctic Ocean new shipping routes will become available and thus shipping activities across the Artic are expected to increase. With the increase in shipping traffic, it is likely that oil spills will occur. For instance, DNV GL (Den Norske Veritas) (in PAME II [2016]) has estimated that "an incident leading to an oil spill is likely to happen every second year within the Bering Sea".

Heavy Fuel Oils (HFO) are produced from a mixture of residual fuel and distillate diluent, for instance marine diesel oil or marine gas oil that is blended to the desired viscosity. HFO consists mainly of residual products from crude oil refining processes, which are low-cost products compared with, for instance, lighter marine fuels, and it is therefore often used as fuel in marine vessel engines (PAME II 2016). HFO and residual fuel oils may also be transported as cargo since pipelines cannot export such high viscous products.

The physical properties as well as the chemical composition of the HFO vary depending on the origin and quality of the residual oil, the distillate and the refinery processes.

Knowledge about the fate and behaviour of oils, including HFO, is important in order to select the most efficient countermeasures in an oil spill situation as well as in the risk assessment of possible oil spills in cold waters. Also, in relation to the Net Environmental Benefit Analysis (NEBA, also called SIMA- Spill Impact Mitigation Assessment) such knowledge is crucial to ensure the best choice of response measures to protect the environment.

This project aims to gather and strengthen the knowledge base on HFO in cold seawater, its fate and behaviour, including aspects such as weathering, biodegradation, environmental implications of HFO oil spills, HFO oil spill response and environmental considerations regarding the use of chemical dispersants and in situ burning as an HFO oil spill response. The report is based on existing literature and results from laboratory weathering tests of HFO performed by SINTEF. Knowledge gaps and research needs on the topics treated are identified and described.

Weathering of HFO will change its physical properties. For HFO types in general, evaporation will be low due to an initially low content of volatile compounds and the tendency to form thick oil slicks that retard evaporation. Natural dispersion is found to be low. Evaporation will lead to increased viscosity, pour point, density and flash point and the oil will therefore remain for a long time on the water surface. Uptake of water (emulsification) also stabilises the oil, leading it to reside longer on the water surface. However, submerging and sinking of HFO, due to a potentially higher density as a result of weathering and/or adsorption of inorganic material in the sea, may also occur.

A new generation of low-sulphur fuel oils, referred to as "hybrid fuel oils", has been developed to meet new requirements and regulations to airborne emissions of 
potentially harmful substances such as sulphur. An increasing number of "hybrid fuel oils" are currently produced and introduced to the market, replacing the traditional HFO types. As HFO types, the new hybrid fuel oils have varying chemical compositions and therefore expectedly exhibit different behaviours and fate characteristics in the case of spillage.

Regarding the potential for natural biodegradation of $\mathrm{HFO}$, the overall finding from this review was that degradation is reduced at cold temperatures and that the rate of degradation is limited by the amount of oil that can dissolve in the water phase. The degradation of HFO in seawater is generally slower compared with medium and light petroleum products. Degradation takes place under anoxic conditions in soils and sediments but at a rate that is half of that under oxic conditions.

The environmental impacts of a marine oil spill are closely related to the physical properties and chemical composition of the oil as well as to the changes caused by the weathering of the oil. Overall, the fate and weathering data on HFO indicate that the major environmental concerns regarding HFO spills are related to the potential effects of HFO on the water surface and on beaches. The low natural dispersion of HFO into the water column adds to the expectation of a relatively low exposure of the organisms in the water column to the HFO in the event of a spill. There is, though, a high risk of physical smothering of seabirds and other sea surface living animal species as well as marine organisms along the coastline. The longest persistence of an HFO spill occurred in soft sediments and on shorelines protected against strong wind and waves. In general, rocky headlands can be quickly cleansed by wave and tidal action. Oil contamination of sediments may persist for a long time and have long-term negative effects on benthic organisms. Preliminary studies have also indicated that smothering by HFO may affect the photosynthetic activity of macroalgae in the tidal zone. Thus, the environmental impacts of HFO types are generally related to surface living species and organisms living in the upper part of the water column and along the coastline, which has been confirmed in connection with the environmental monitoring of four Norwegian HFO spill accidents.

The potential for countermeasures to respond to an HFO spill is highly influenced by the high viscosity of the oil as well as the high pour point and the ability to form stable water-in-oil emulsions. Moreover, the time window for chemical dispersibility and in situ burning may be relatively short. However, it may be possible to perform a successful dispersion in some cases, but successive application of the chemical dispersant might be needed, depending on the stability and viscosity of the water-inoil emulsion. Mechanical recovery measures should be either low-tech methods or systems developed specifically to such highly viscous products.

Review of the environmental implications of the different response measures showed that HFO, which is chemically dispersed, is in general more toxic in the environment than the oil itself due to a higher degree of bioavailability of the dispersed oil. Also, to obtain sufficient dispersing efficiency, the ratio of dispersant to HFO (Dispersant Oil Ratio, DOR) may need to be increased, DOR 1:10, i.e. up to 2-fold volume of dispersants and/or several applications may be necessary for successful dispersion of HFO compared to lighter oil types (with typical DOR of 1:25). Thus, if the 
oil slick is missed during the possibly several needed application operations, or the weathering state of the spilled HFO makes it not dispersible, a comparable larger volume of potential toxic dispersants is added to the environment. This will have to be considered in the Net Environmental Benefit Analysis (NEBA) prepared for a potential dispersing operation. If the HFO spill is successfully dispersed, the resulting higher exposure of organism in the water column, e.g., zooplankton and fish, must be taken into account in the NEBA.

Regarding in situ burning, and for consideration in connection with preparing the NEBA for such an operation, our review indicated an increase of heavy (high ring number) Polycyclic aromatic hydrocarbons (PAHs) in the burn residue from combustion, which may prolong the long-term exposure of the environment as heavier PAHs have a higher potential for bioaccumulation and also may include mutagens and carcinogens. On the other hand, more water soluble and bioavailable compounds are reduced and the total amount of the oil is considerable reduced. The formation of smoke and soot is a matter of both environmental and health concern, in particular regarding inhalable particles and particle deposits. Thus successful burning of HFO may reduce considerably the amount of oil left in the environment. However, a higher proportion of a more toxic and a less degradable oil fraction may be left in the environment since the proportion of volatile and dissolvable components is smaller.

This review revealed a need for large-scale studies and experiments on HFO in ice and increased knowledge of HFO recovery/removal from the environment, identification of a window of opportunity for conduct of dispersant and in situ burning operations as well as gathering of information on HFO degradation in the environment (weathered and chemically dispersed) and the fate and effect of HFO (different oil fractions and ecotoxicity, including smothering). To allow comparison of hybrid fuel oils, it is important to follow up the coming years with further characterization of the different new fuel oils coming on the marked. The aim is to gain better documentation of the span and variability in the fate and behaviour of the new products in case of spill at sea and to document the potential/feasibility of the different response options as well as their environmental impacts. 


\section{What is HFO - definitions}

Heavy Fuel Oil (HFO) is one of several terms used to cover a rather broad range of different marine residual fuels and some distillate fuels (DNV 2011). Other often used terms are bunker oil, bunker fuel oil, residual fuel and heavy diesel oil. Common to them all are that they are used on board ships and the terminology therefore allows distinction of HFO from, for instance, crude oils and other refined products (Lewis 2002).

$\mathrm{HFO}$ is produced from a mixture of residual (residual fuel) and cutter stock (distillate diluent, for example marine diesel oil or marine gas oil) blended to achieve, for instance, the desired viscosity at a specific temperature (often $50{ }^{\circ} \mathrm{C}$, an earlier indicator for storage) (Lewis 2002). No standard exists for the blend of residue and distillates to produce HFO (Moldestad et al. 2007). The properties, both physical and chemical, of the HFO will thus vary depending on the origin of the feed oil (crude oil), the quality or properties of the feed oil, variations of the distillate added to produce the required viscosity and the different refinery processes (Moldestad et al. 2007; Lewis 2002). The latter include: atmospheric distillation, vacuum distillation, thermal cracking processes (e.g. visbreaking) and other conversion processes such as catalytic cracking and hydrocracking (Moldestad et al. 2007). For more details about the processes, consult Moldestad et al. (2007). Today, most residual fuel oils are produced using vacuum distillation and thermal and catalytic cracking (Moldestad et al. 2007). The engine ignition characteristics of these fuel products are normally good due to the content of paraffins in the atmospheric distillate.

In the following, the most often used classification systems will be described, including the definitions of the different properties of the oil.

\subsection{IFO grade system}

HFO types are often classified according to the "Intermediate Fuel Oil (IFO) Grade system" (Moldestad and Daling 2006), where viscosity (cSt, centi Stoke ${ }^{1}$ ) is specified at $50^{\circ} \mathrm{C}$ as an indicator for the oil's ability to be pumped (Moldestad and Daling 2006). Sixteen IFOs are available in the IFO viscosity classification system, ranging from IFO30 to IFO700. Since the IFO system only specifies the viscosity of the fuel, all other properties may vary (Lewis 2002).

The most widely used products are $\mathrm{IFO}_{3} 80$, accounting for $70 \%$ of the total volume of heavy bunker oils supplied, followed by IFO180, constituting approximately $25 \%$ of the volume of bunker oil on the market (Lewis 2002). Other grades account for the remaining $5 \%$ (Moldestad et al. 2007).

${ }^{1}$ Note that the $\mathrm{SI}$-unit for viscosity is $\mathrm{mPa}$.s. The unit CP (centipoise) is commonly used in the oil industry and cSt is used to measure the specific temperature of $50^{\circ} \mathrm{C}$. 


\subsection{ISO classification system}

In the ISO 8217 "Specification of Marine Fuel" standard other terms for defining residual and distillate fuels are specified. The classification Residual Marine (RM) is used, RM180 being equivalent to $\mathrm{IFO}_{180}$. Designated property is viscosity $\left(50^{\circ} \mathrm{C}\right)$, but other properties such as density, carbon residue and ash content are also included. To indicate this in the classification, a letter $(A, B, \ldots)$ is added to the index to determine the parameters.

Table 1 shows a comparison of the IFO grade and ISO classification systems of residual oils. The properties compared are density, content of distillate/residue volume percentage, and viscosity.

Table 1: Comparison of the IFO grade and ISO classification systems of residual oils. The properties compared are density, content of distillate/residue volume percentage and viscosity.

\begin{tabular}{|c|c|c|c|c|}
\hline IF grade & ISO grade & Density [kg/L] & Destillate ("flux") [Vol\%] & Heavy residue [Vol\%] \\
\hline $\mathrm{IF}_{30}$ & RM10 & 0.93 & $35-40$ & $60-65$ \\
\hline IF8o & $\mathrm{RM} 15$ & $0.93-0.96$ & $18-30$ & $70-80$ \\
\hline $\mathrm{IF}_{180}$ & $\mathrm{RM}_{25}$ & $0.94-0.97$ & $5-20$ & $80-92$ \\
\hline IF 240 & & $0.96-0.98$ & $3-12$ & $90-95$ \\
\hline $\mathrm{IF}_{380}$ & RM35 & $0.97-0.99$ & $0-10$ & $90-100$ \\
\hline $\mathrm{IF}_{460}-650$ & $\mathrm{RM}_{55} \rightarrow$ & $1.0-1.05$ & $0-10$ & $90-100$ \\
\hline
\end{tabular}

Source: The table has been adapted from Moldestad and Daling (2006)

\subsection{MARPOL definition}

Regulation 43 in Annex 1 of MARPOL (International Convention for the Prevention of Pollution from Ships) concerns the protection of Antarctica from pollution by heavy grade oil. The regulation prohibits carrying fuel in bulk as cargo and/or using fuel with certain specific properties (IMO 2011):

- crude oils having a density higher than $900 \mathrm{~kg} / \mathrm{m} 3$ at $15^{\circ} \mathrm{C}$

- oils other than crude oils having a density higher than $900 \mathrm{~kg} / \mathrm{m} 3$ at $15^{\circ} \mathrm{C}$ or a kinematic viscosity higher than $180 \mathrm{~mm} 2 / \mathrm{s}$ at $50^{\circ} \mathrm{C}$

- bitumen, tar and their emulsions.

\subsection{DNV GL definition}

In the report "Heavy fuel in the Arctic (Phase 1)" (DNV 2011), HFO is characterised as in the regulations for the Antarctic, and in the report "Marine environmental risk assessment - Greenland" (DNV GL 2015) HFO is defined as a residual marine fuel with a viscosity $>180 \mathrm{cSt}$ (centi Stoke) at $50^{\circ} \mathrm{C}$. 


\subsection{Other often used terms/definitions}

- $\quad$ The British Standard (BS) classification system (BS 2869:83) for residual burner fuels (Moldestad et al. 2007).

- $\quad$ ASTM (American Society for the Testing of Materials) developed a standard for fuel oils, including heavy residual oil (ASTM D396-80). By way of example, No. 5 (Heavy) Fuel is defined as a fuel that requires preheating for burning and in cold climates this may be required for handling (Moldestad et al. 2007). Fuel No. 6 was/is often named Bunker $C$ and is a residual fuel oil where preheating is required for both burning and handling.

- In France, marine residual fuel oil is often categorised as Fuel oil No. 1 (light residual oil) and Fuel oil No. 2 (heavy residual oil) (Moldestad and Daling 2006).

To sum up all the different definitions (Lewis 2002):

"...the single description [of HFO] conceals variations in sources, properties and likely behaviour of the spilled oil that will be useful information when planning or conducting response to spills of heavy fuel oils. There is no universally accepted definition of heavy fuels oils except that they are based on the residues from various refinery processes. They are therefore also known as residual fuel oils."

In this report we will use either the term HFO or residual oil as overall term for oils within the different ranges described above. Thus, we will include available information on all oil types within this range of refined oil products regardless of the specific name/classification system. 


\section{Air emissions from HFO}

Fossil fuels, including HFO, contain sulphur. During combustion (in the engine), sulphur is oxidised to sulphur dioxide $\left(\mathrm{SO}_{2}\right)$ that again can be oxidised to sulphur trioxide $\left(\mathrm{SO}_{3}\right)$ and sulphate ( $\mathrm{SO}_{42-}$ ) (generally termed sulphur oxides, $\mathrm{SOx}$ ) after emission to the atmosphere. Moreover, nitrogen oxides (NOx) are emitted during combustion. The resulting air pollution from, for instance, ships may have cumulative negative effects, leading to, for instance, severe human health problems as well as detrimental environmental impacts such as acid rain.

MARPOL Annex $\mathrm{VI}$ was revised and strengthened to reduce the global emissions of NOx, SOx and particulate matter (PM) and to introduce Emission Control Areas (ECA) with the aim to further reduce air pollution in designated areas (IMO 2016).

In relation to NOx, ships built after 2015 are required to reduce their NOx emissions by $75 \%$ relative to current emission standards for international shipping (PBL 2012) in "Nitrogen Emission Control Areas" (NECA).

\subsection{Sulphur}

According to ISO $8217: 2015$, the sulphur content in residual oils is defined by statutory requirements such as national or international emission requirements (e.g. the EU Sulphur Directive). On-land uses of HFO for, for instance, power generation and other industries are limited to HFO with a sulphur content of maximum 1\% (Moldestad et al. 2007; MST 2014).

In EU, the Baltic Sea and the North Sea, SOx Emission Control Areas (SECA) with a limit of the sulphur content of $0.1 \%$ have been established, effective as from January 2015 (PAME 2016). Furthermore, a global $0.5 \%$ sulphur limit is expected to come into force in 2020 (IMO 2017). Emission control areas have also been established in North American areas and United States Caribbean Sea areas (IMO 2017).

Figure 1 is based on input data from the PAME (2016) report on the expected development in the HFO sulphur content. 
Figure 1: Expected development in sulphur content in HFO

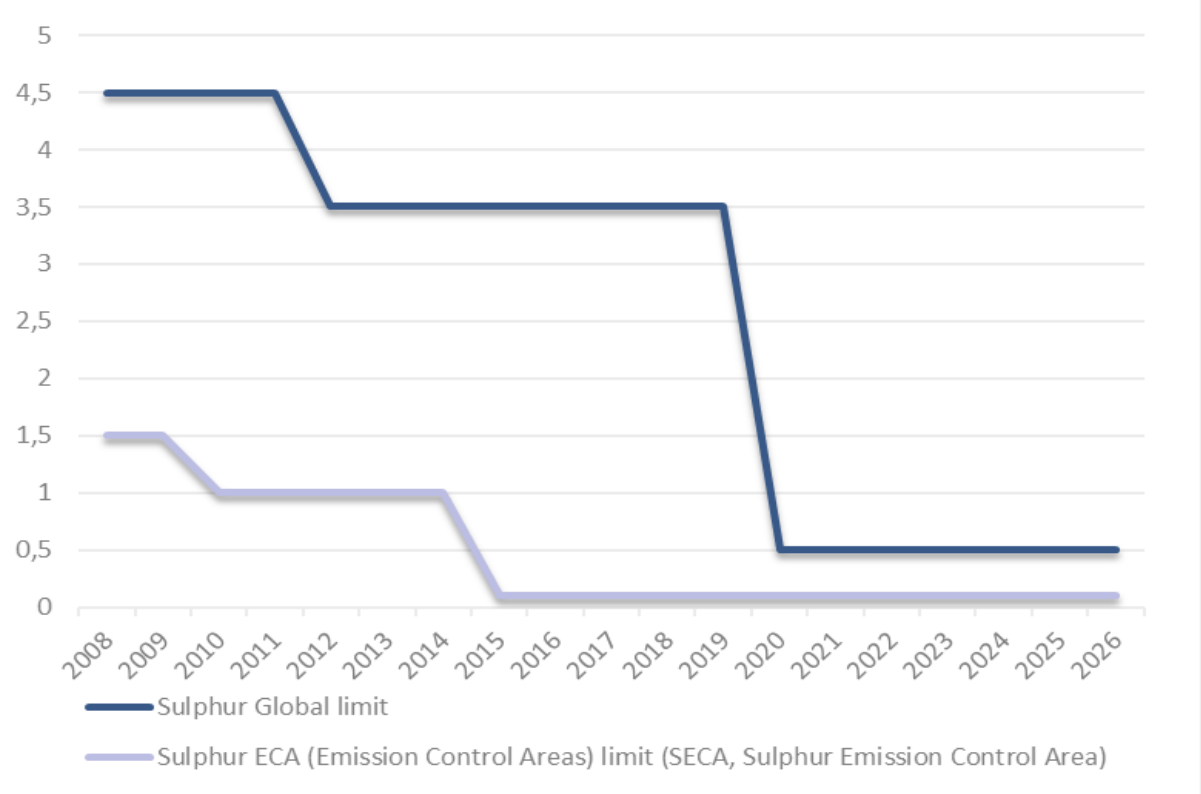

Source: Figure based on input data from PAME (2016).

The SECA limit as well as the expected global sulphur limit will require the use of lowsulphur feed oil such as low-sulphur crude oils. The DNV GL report "Shipping 2020" (DNV 2012) simulated the development of the world fleet from 2012-2020 using different scenarios. Of interest in this context is that, they included the $0.5 \mathrm{global}$ sulphur limit scenario (as introduced in 2019), and hence the HFO demand is simulated to drop from approximately 290 million tonnes to 80-110 million tonnes (DNV 2012). Further, "HFO in the Arctic Phase II report" (DNV 2013) predicted that the global $0.5 \%$ sulphur cap will change the type of bunker fuel in use towards lighter products/distillates. It is important to note that this will still not comply with the marine gas oil standard.

Ship owners are concerned that low sulphur marine fuels will increase costs, in particular as regards emission control. To prevent this, MARPOL allows the use of exhaust gas cleaning systems (e.g. scrubbers) or other technologies to limit emissions of SOx to levels that are comparable with the emissions from low sulphur fuel (Kjølholt et al. 2012). Thus, the sulphur limits will lead to either an increased use of exhaust gas cleaning or reduced use of high sulphur oils. It is uncertain how the actual characteristics of these lighter products will be with respect to evaporation, dissolution, dispersion, water uptake/emulsification and environmental effects compared with the currently applied HFO oils. However, low-sulphur crude oils tend to be rich in waxes, resulting in a higher pour point also for the products produced from them; therefore, Moldestad et al. (2007) anticipate that the future marine bunker fuel oils to be used in EU waters will have significantly higher pour points. A high pour point is a challenge in relation to oil spill response. 
A possible alternative method to ensure compliance with the regulation is cleaning of the exhaust gases using wet and dry scrubbers. The main purpose of the application of both wet and dry scrubbers is to remove sulphur oxides from the exhaust streams. An additional positive effect is that particulate matter is trapped in the exhaust, reducing air emissions of heavy metals, soot, PAHs as well as sulphur bonded to the particles. However, wastewater from scrubbers may contain PAHs, metals, dioxin etc., and use of scrubbers could possibly transform an air pollution problem into a marine environmental problem.

\subsection{Hybrid fuels oils}

A new generation of fuel oils has been developed and is produced in order to meet new requirements to and regulations of airborne emissions of potentially harmful substances such as sulphur. Today, these new fuels are regularly used as bunker fuel in the SECA (Sulphur Emission Control Areas) areas in Europe (Hellstrøm et al. 2017). The sulphur content of these products is less than $0.1 \%$ and they may be referred to as hybrid fuel oils. Hybrid fuel oils can be used in engines originally designed for combustion of HFO. Use of the new generation of low-sulphur hybrid oils may increase as an alternative to implementing the scrubber technology.

As HFO, hybrid fuel oils are produced in different ways and have varying chemical compositions and they will therefore behave differently in case of discharge to the environment; thus, a wide span in weathering properties is expected. Consequently, it is highly important to characterise the new fuel oils on the market, to gain better documentation of the differences in fate and behaviour in case of a spill at sea and to document the potential / feasibility of the different response options. 


\section{Use of HFO in the Arctic}

The dominant fuel used in shipping is HFO since it is relatively inexpensive; typically, it costs $30 \%$ less than distillate fuels.

The PAME report: Possible hazards for engines and fuel systems using heavy fuel oil in cold environments (PAME 2016) aimed to reveal if use of HFO in engines in the Artic resulted in relatively more fuel system failures than use of other fuel types (PAME 2016). The overall findings from the study were that:

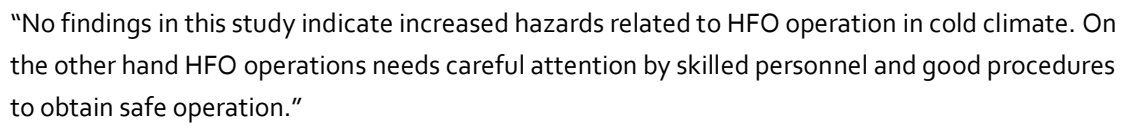

In more detail, utilising HFO requires that the fuel is pre-heated to ensure that it is sufficiently fluid for pumping, separation etc. In cold climates, such as the Artic, the need for heating may typically be higher. Further, in the case of machinery experience blackout, the available time for restart will expectedly be shorter due to more rapid cooling of the machinery in cold climates (from DNV 2011).

In the DNV GL report for PAME - HFO in the Arctic - Phase 2 (DNV 2013), a series of studies predicting future shipping in the Arctic was reviewed and common to all was that they predicted increased traffic; however, the findings are involved with a high degree of uncertainty.

In relation to use and carriage of $\mathrm{HFO}$ in the Arctic, no particular regulations exist apart from a few national and local requirements. An example is the ban on use and carriage of HFO in the national parks on the east side of Svalbard and in the three large national parks on the west side of Svalbard (Sysselmannen 2017).

The new requirements to and regulations of airborne emissions of potentially harmful substances such as sulphur have, as described in Chapter 2, led to the development and use of new fuel types such as hybrid fuel oils. The regulation of airborne emissions does not stipulate requirements for the specific oil types, but it is likely that new requirements will lead to more extensive use of lighter products (according to the DNV GL report [PAME II 2013]) and the new hybrid fuel oils. 


\section{Weathering studies on HFO}

\subsection{Physical and chemical parameters}

Knowledge about the original chemical and physical properties of oil accidentally spilled at sea is important as these will determine its behaviour and are important in predicting the fate of the oil and the oil spill countermeasures to be applied. If the grade of the fuel oil is known, so is the viscosity measured at $50^{\circ} \mathrm{C}$. However, it is most likely inaccurate to convert this oil viscosity to the lower seawater temperatures as the oil exhibits non-Newtonian behaviour at low temperatures (Lewis 2002). In addition, as stated in Chapter 1, the physical and chemical properties of a fuel oil will vary depending on its origin and the refinery processs. Thus, important parameters besides viscosity are density, pour point, volatile compounds and content of asphaltenes, resins or waxes in order to predict the fate of the oil after spill in a marine environment. From a safety point of view, also the flash point is important relative to fire/explosion hazards.

Viscosity is a measure of the resistance of the fuels to flow. The viscosity of oil increases with decreasing temperatures and vice versa, and information on viscosity must therefore always include the temperature at which the viscosity was determined (ABS 2001). In addition, non-Newton oils demonstrate a shear-thinning behaviour where the viscosity decreases when the shear rate increases (reciprocal second, $\mathrm{s}^{-1}$ ).

Density is important as it gives an indication of where the fuel can be found and hence the potential for submerging and/or sinking of the fuel.

Pour point is the temperature at which the oil solidifies and it thus provides information on the behaviour (e.g. solid or not) of the fuel at various sea temperatures. Solidification typically occurs when the pour point of the oil is $10-15^{\circ} \mathrm{C}$ above the sea temperature. The pour point is related to the oil's wax content. When the temperature decreases, the waxes in the oil crystallise, and the crystalline wax structure prevents flow. The cloud point is the temperature where waxes start to precipitate. Fuel oils with origin in waxy and paraffinic crude oils will most likely have a high pour point (Moldestad and Daling 2006). Naphthenic oil will generally thicken upon cooling (ABS 2001).

Knowledge about the content of asphaltenes, resins or waxes in the fuel is also important as these compounds influence the stability of the water-in-oil emulsification (Faksness 2008). The polar part of asphaltenes interacts with the oil-water interphase. Wax contributes to stabilising the asphaltenes in the oil-water interphase position (Hellstrøm et al. 2017). Therefore, a high wax content and a small asphaltene content will most likely yield an unstable emulsion.

Volatile compounds (VOC) are generally defined as compounds with a boiling point lower than $250^{\circ} \mathrm{C}$ (i.e. up to $\mathrm{nC}_{14}$ ). These are thus the part of the HFO that most easily evaporates, resulting in increased viscosity of the oil. 


\subsection{Fate and behaviour of HFO in cold seas}

The general fate and behaviour of oil have been described in many reports and articles. An overview of the processes affecting the fate and behaviour of oil in open waters and under ice-covered conditions is given in Figure 2.

Figure 2: Weathering of oil on open water as well as in ice-infested waters

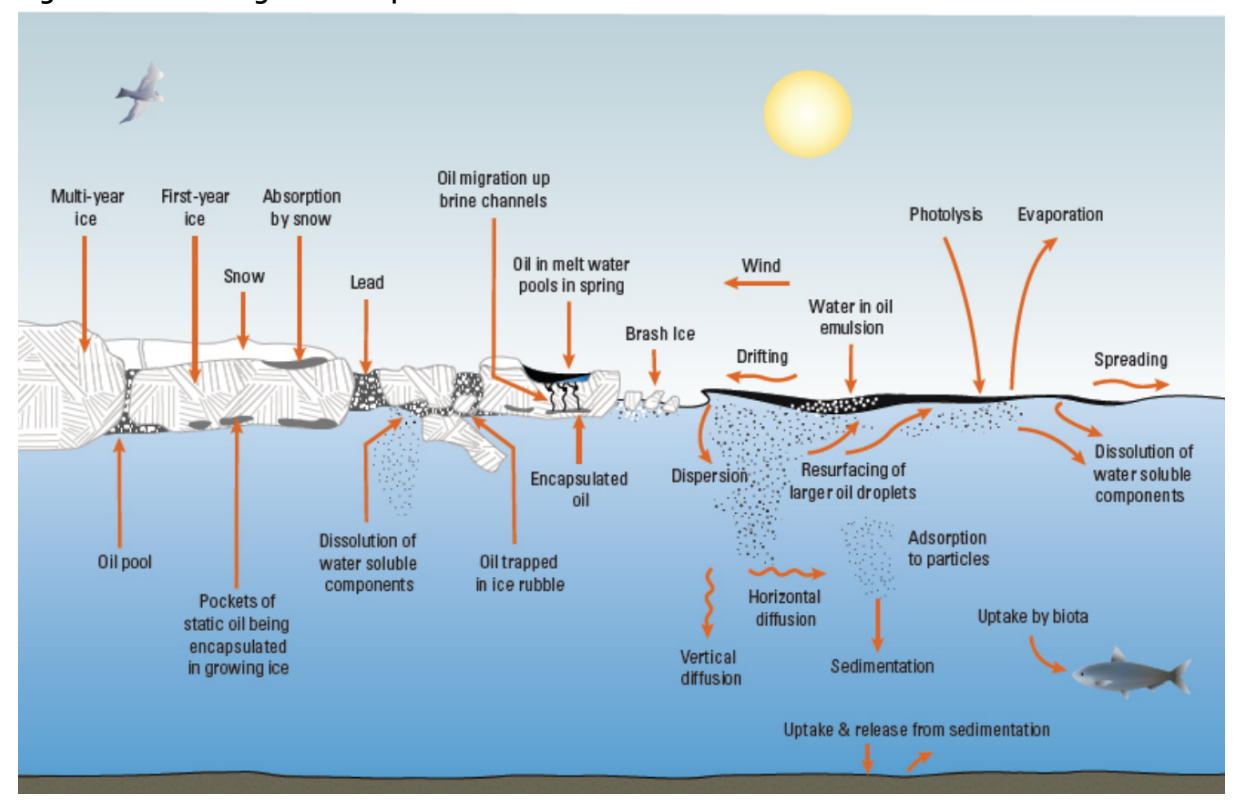

Source: From National Research Council (2014), Modified from Daling et al. (1990a) and A. Allen.

The first processes occurring are spreading of the oil slick and evaporation of the most volatile compounds. If ice is present, these processes will be limited by the available icefree water surface and by the wave dampening. A small proportion of the compounds in the oil is water soluble, but these compounds are typically also those that evaporate fast. In general, the prevailing wind and wave energy in the system influences the fate of the oil. With time also emulsification, where the oil takes up water (water-in-oil emulsification), will change the properties of the oil by increasing the viscosity and volume. Parts of the oil may also disperse naturally into the water column. Emulsification and dispersion are both processes that depend on the energy in the system; thus, in ice-covered waters the processes will be slower due to the dampening effect of the ice on the wind and wave energy. However, a certain interaction may take place due to the movements of the ice floes. In the longer run, biodegradation and photo-oxidisation will impact the fate of the oil and the oil properties. Biodegradation in relation to HFO is described in Chapter 6 below.

Simultaneously with the weathering processes, the oil will drift depending on the prevailing current and wind.

The weathering of the oil will change its physical-chemical properties. Evaporation will lead to increased viscosity and a higher pour point, density and flash point. The rate of the evaporation will depend, on among other things, film thickness, wind speed and 
temperature as well as the original content of VOC. Emulsification stabilises the oil on the water surface, increasing the viscosity and the volume of the oil. On the other hand, natural dispersion will remove the oil from the water surface, but as evaporation and emulsification processes increase the viscosity of the oil, the natural dispersion rate will decline.

\subsection{Main findings from SINTEF weathering experiments and modelling including HFO}

Since the late 1980 s, SINTEF has built up their laboratory capacity to include equipment investigating the fate and behaviour of oil (e.g. Daling et al. 1990b). Both small- and meso-scale experimental set-ups to determine the expected oil weathering at sea are available. The small-scale experiments involves use of a stepwise approach where the different weathering processes are completed consecutively. The weathering processes consist of evaporation (topping) by use of a modified method (ASTM D86/82 distillation [Daling et al. 1990b]) and emulsification of the distillate by use of the rotating flask technique (modification of method of Mackay and Zargorski [1982]).

It is important to be aware that the weathering processes are linked and influence each other. For this purpose, SINTEF has built an oil-weathering flume allowing occurrence of oil weathering simultaneously under, for instance, simulated Arctic weathering conditions (low temperatures).

In addition, SINTEF has developed a model (SINTEF Oil Weathering Model [OWM]) that, based on input data from the laboratory experiments, is able to predict the fate and behaviour of the oil at sea.

Both small-scale and meso-scale experiments and the SINTEF OWM model have been verified against the results of large-scale field experiments, and they have proven to provide reasonable correlations.

In the following, three reports by SINTEF on the weathering of HFO in cold environments are reviewed and the major findings are presented below. Several types of HFO are included in the studies behind the reports as well as in the comparisons with other lighter refined products and crude oils. In addition, the main findings from a recent study including hybrid fuel oils are described.

The reports include:

- Moldestad and Daling. 2006. Vurdering av forvitringsegenskapene til ulike Marine Gassoljer. Kriterier for fastsettelse av drivstoff kvalitet ut fra egenskaper ved et eventuelt utslipp. SINTEF report no. STF8oMK Ao6170 (in Norwegian).

Weathering of different fuels ranging from light marine gas oils to marine residual fuel oils (IFO30 and IFO380) was analysed using SINTEF OWM and laboratory analyses. The weathering seawater temperature was $0^{\circ} \mathrm{C}$ and the wind speed was $10 \mathrm{~m} / \mathrm{s}$. The results of the analyses were used as input data in the assessment behind the regulation of use of fuel on Svalbard (Moldestad and Daling 2006). Different figures from the report are assembled in Figure 3. 
Figure 3: Natural dispersion /entrainment, water content and remaining oil on the surface after weathering at $0^{\circ} \mathrm{C}$ and $10 \mathrm{~m} / \mathrm{s}$ predicted using SINTEF OWM
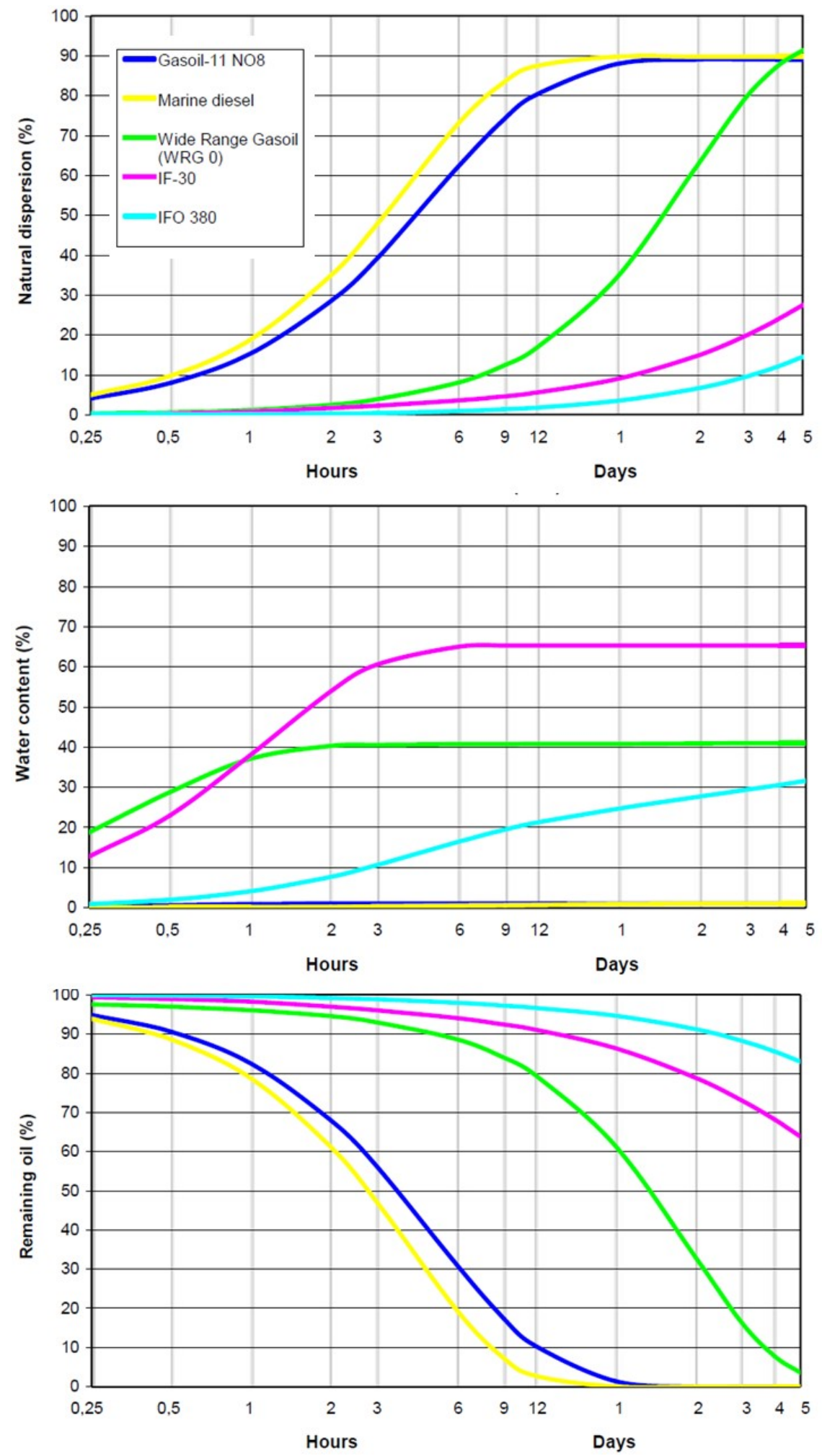

Source: From Moldestad and Daling (2006). 
Both gas oil and marine diesel (dark blue and yellow lines) are removed fast from the water surface; thus, within a couple of hours the major part of these products are no longer present on the water surface. The light/low viscous gas oil and marine diesel form very thin oil films on the sea surface. Under the influence of breaking wave conditions ( $>5 \mathrm{~m} / \mathrm{s}$ wind), the oil films rapidly disperse naturally into the water column ( $90 \%$ after approximately one day). Also, these two oil types do not generate emulsions. Due to low viscosity (typically below $1000 \mathrm{CP}$ ), the oil that remains on the water surface for a couple of hours will expectedly be difficult to collect by active boom containment.

Wide range gas oil (WRG, a heavier distillate than MGO [Marine Gas Oil]) will stay longer on the water surface and create a residue with a high wax content (Moldestad and Daling 2006). According to the SINTEF OWM results, WRG creates emulsions that may solidify and have a relatively high viscosity, rendering recovery by use of skimmers and pumps difficult.

Contrary to this, the two types of $\mathrm{HFO}_{1} \mathrm{IF}_{30}$ and $\mathrm{IF}_{3} 80$, will remain much longer on the water surface (pink and light blue lines) as their natural dispersion is expectedly low. Moreover, especially IF3o takes up water: $65 \%$ after 6 hours.

Based on the findings in the report (Moldestad and Daling 2006), it was recommended that only marine gas oils are used as a fuel in specific sensitive areas on Svalbard since they disperse naturally and relatively fast into the water column. Marine gas oils were also the only products tested that did not leave a residue on the water surface to be handled. The report further recommended more detailed studies to be conducted since the data were subject to some uncertainty.

- Strøm and Guyomarch, 2008. Weathering properties and dispersability of one Russian Crude (REBCO) and one HFO Bunker fuel. SINTEF Report no. SINTEF A8569.

The objective of the joint project of SINTEF and CEDRE was to study the physical and chemical properties as well as the chemical dispersibility of a Russian crude oil (REBCO) and a Russian heavy bunker fuel (Vysotsk IFO380). The project involved laboratory experiments with stepwise weathering whose results formed the input to the SINTEF OWM predictions of the behaviour and fate of the oil. The predictions were made for a temperature of $5{ }^{\circ} \mathrm{C}$ and a wind speed of $10 \mathrm{~m} / \mathrm{s}$. The results were compared with findings for other bunker oils, IFO30-IFO650, from the Prestige incident (further details can be found in Chapter 5). Selected figures from the report are gathered in Figure 4 . 
Figure 4: Evaporation, water content, viscosity and pour point change for different HFOs weathered at $5^{\circ} \mathrm{C}$ and $10 \mathrm{~m} / \mathrm{s}$ wind speed
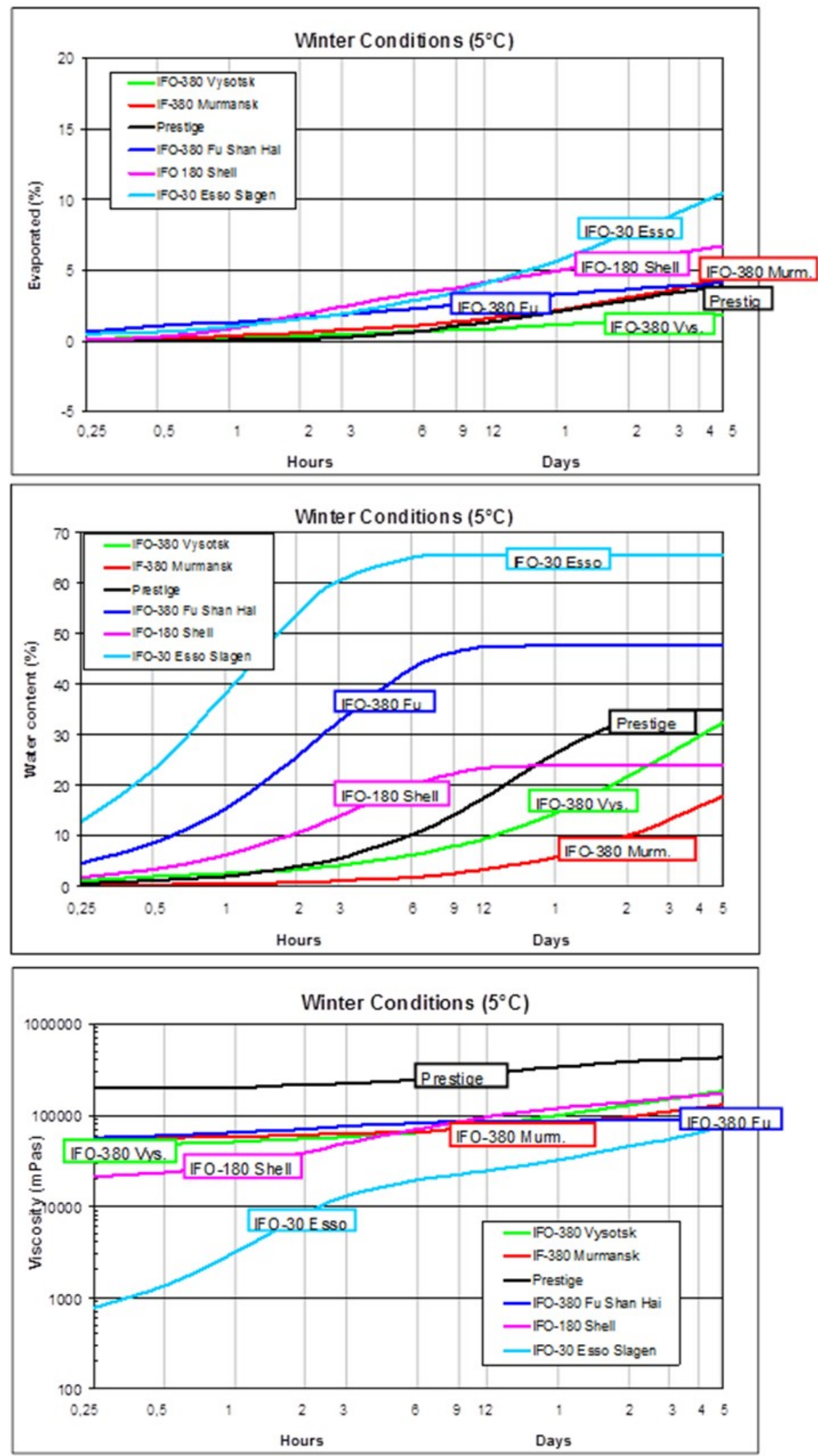

Source: From Strøm, T. and Guyomarch, J. (2008). 
When comparing the change in the physical and chemical properties as a function of weathering time for the six different HFOs (see Figure 4), it is evident that both the change in trends as well as the initial levels of the properties vary between them. This is the case even for HFOs having the same viscosity at $50^{\circ} \mathrm{C}$.

However, common to all the HFOs shown in Figure 4 is that the viscosity and pour point (as well as the density and flash point, as seen in Strøm and Guyomarch [2008]) increase with time. The water uptake increases until the oil specific maximum level is reached. The maximum water content varies from $25 \%$ to $65 \%$ (Figure 4 ).

For the specific HFO tested in the study (Vysotsk, IFO380), the SINTEF OWM predicted that after one day of weathering at $5^{\circ} \mathrm{C}$ and at $10 \mathrm{~m} / \mathrm{s}, 2-3 \%$ of the oil would have evaporated (this is considered to be very low) and the water uptake would be less than $20 \%$. The resulting viscosity of the emulsion was around $100,000 \mathrm{CP}$ at $5^{\circ} \mathrm{C}$. IFO 380 appeared to be dispersible - however, only to a very limited extent at water temperatures of $0^{\circ} \mathrm{C}$.

- Moldestad and Resby, 2001. Forvitringsegenskapene til IF180 oljer fra Statol, Shell og Esso. SINTEF Report no. STF66 Aooog4 (in Norwegian).

SINTEF tested three different IFO 180 residual oils at $2{ }^{\circ} \mathrm{C}$ in laboratory small-scale stepwise weathering experiments. One of the oils was also tested in a meso-scale weathering flume.

The experiments revealed that even though the three oils tested belonged to the same category, they showed quite significant differences in fate and behaviour. The variations of the residual oils are due to 1 ) different properties of the heavy residue and the light distillate from which the IFO180s are blended as well as 2) the specific refinery process (Moldestad and Resby 2001).

Table 2 (data from Moldestad and Resby (2001)) shows the different properties of three different IFO 180 s weathered for 24 hours at $2^{\circ} \mathrm{C}$ and $10 \mathrm{~m} / \mathrm{s}$ (SINTEF OWM data). Furthermore, data after 5 days of weathering have been included in the table. The three oils clearly behave differently, but some general trends emerge such as low evaporation, increased viscosity and formation of emulsions.

The stability of the emulsions for the three IFO180s was tested and all the emulsions were found to be highly stable during the 24 hours of settling (i.e. limited drain out of water during the standstill) (Moldestad and Resby 2001). This is important knowledge in relation to oil spill response, i.e. storage capacity.

The meso-scale experiment demonstrated that within the first day, the water content was $35 \%$ due to the encapsulation of larger water droplets. However, after continued weathering in the flume, the water content slowly decreased to $20 \%$ because the large water droplets gradually were broken down to smaller droplets. Often emulsion breakers are used to remove water from the collected emulsion, thereby reducing the volume that needs to be stored. However, the emulsion breaker Alcopol $O$ $60 \%$ could not break the emulsions for Shell IFO180 in a small-scale test experiment, probably due to the high viscosity at $2^{\circ} \mathrm{C}$. 
Table 2: Weathering properties of three different IFO 180 oils. Weathering predicted by SINTEF OWM at $2{ }^{\circ} \mathrm{C}$ and $10 \mathrm{~m} / \mathrm{s}$

\begin{tabular}{|c|c|c|c|c|c|c|}
\hline \multirow{2}{*}{$\begin{array}{l}\text { Properties } \\
\text { Weathering }\end{array}$} & \multicolumn{2}{|c|}{ Statoil } & \multicolumn{2}{|c|}{ Shell } & \multicolumn{2}{|c|}{ Esso } \\
\hline & 24 hours & 5 days & 24 hours & 5 days & 24 hours & 5 days \\
\hline Evaporation [\%] & 6 & 12 & 4 & 6 & 2 & 3 \\
\hline Pour point $\left[{ }^{\circ} \mathrm{C}\right]$ & -2 & 10 & 1 & 4 & 24 & 24 \\
\hline Water content $[\%]$ & 23 & 25 & 20 & 20 & 20 & 20 \\
\hline Viscosity (water-free oil) [CP, at shear rate 10] & 35,000 & 100,000 & 60,000 & 110,000 & 40,000 & 50,000 \\
\hline Viscosity (emulsion) $[\mathrm{CP}$, at shear rate 10$]$ & 60,000 & 200,000 & 200,000 & 400,000 & 55,000 & 70,000 \\
\hline Density $\left[\mathrm{Kg} / \mathrm{m}^{3}\right]$ & 980 & 990 & 985 & 990 & 965 & 965 \\
\hline
\end{tabular}

Source: Data are found in Moldestad and Resby (2001).

\subsubsection{Hybrid fuel oils}

To meet the new requirements to airborne emissions a new generation of fuel oil has been developed and produced that may be referred to as hybrid fuel oils (see Chapter 2). A recent project by SINTEF conducted for the Norwegian Coastal Administration (NCA) included laboratory weathering studies on hybrid fuel oils if spilled at sea at cold temperature conditions as well as identification of the potential of different response methods (chemical dispersibility and ignitability) (Hellstrøm 2017 and Hellstrøm et al. 2017). The two hybrid products tested were HDME 50 from ExxonMobil and ULSFO from Shell. ${ }^{2}$ The general findings from the resulting two reports (Hellstrøm 2017 and Hellstrøm et al. 2017) are presented below.

The physical properties and the chemical composition of the two hybrid oils tested vary. ULSFO has a higher content of asphaltenes and wax than HDME 50. In general, the contents of wax and asphaltenes are higher for the hybrid oils compared with the tested diesel oil.

HDME 50 has little or no content of lighter components $\left(<\mathrm{C}_{15}\right)$ and the flash point was measured to $186^{\circ} \mathrm{C}$ for the fresh oil. Stable emulsions were found up to a water content of $68 \%$ and a viscosity of $9500 \mathrm{mPa} \cdot \mathrm{s}$ at $13^{\circ} \mathrm{C}$. At colder conditions, the viscosity of the emulsion was higher due to the high pour point, which also resulted in poor chemical dispersibility.

ULSFO has low evaporative loss and a wax content that result in a high pour point, which makes the oil solidify at low temperatures. The oil forms stable emulsions in tests at $13^{\circ} \mathrm{C}$. The high pour point at low temperatures will affect the chemical dispersibility of the oil and oil emulsions. It is considered that the window of opportunity for successful dispersion of ULSFO (oil and emulsions) is for viscosities below $4000 \mathrm{mPa} \cdot \mathrm{s}$ at $13^{\circ} \mathrm{C}$.

\footnotetext{
2 HDME$_{50}$ is a heavy distillate, while ULSFO is a residual oil. These two hybrid oils are presently the dominant hybrid oils used in Europe. However, many refineries have started producing "hybrid" products, so it is expected that a wide range of low-sulphur hybrid oils will be marketed in the coming years.
} 
Meso-scale weathering experiments including both hybrid oils (HDME 50 and ULSFO) revealed that the viscosity of emulsions was lower at $2{ }^{\circ} \mathrm{C}$ than at $13^{\circ} \mathrm{C}$, which may explain the higher dispersion effectiveness at this colder temperature. However, in general, the potential of dispersion is considered to be low for the two tested oils.

Ignitability of the ULSFO was tested in a small-scale burning cell $(\sim 0.1 \mathrm{~L})$ and in a somewhat larger test set-up ( $5 \mathrm{~L}$ of oil). The fresh ULSFO ignited easily; however, sustainable burn of evaporated and emulsified samples of ULSFO was difficult to establish, and extended ignition was required. The predicted window of opportunity for in situ burning was less than 2 days at $0^{\circ} \mathrm{C}$ and $2 \mathrm{~m} / \mathrm{s}$. HDME 50 appeared more difficult to ignite due to the high flash point, but was ignitable with a highly extended ignition period. Predictions of the window of opportunity for in situ burning showed that the oil is expected to be ignitable up to 5 days at $0^{\circ} \mathrm{C}$ and $2 \mathrm{~m} / \mathrm{s}$ due to the slow emulsification at the low temperatures. It should be emphasised that only ignitability was tested and more studies are thus needed to evaluate the full "in situ burning" potential.

If mechanical methods are considered for recovery of hybrid fuel oils, the choice of skimmer should accommodate the expected emulsion viscosities and pour point, to ensure an effective recovery.

The large variability between the hybrid oils may also be reflected in their toxic effects on marine life. In addition, due to the large variations in physical properties, for instance viscosity, the oils may require different countermeasures in a spill situation. Further characterisation of the new fuel oils coming on the market is therefore required to obtain better documentation of the variability in fate and behaviour as well as environmental impacts in the event of a spillage at sea.

\subsection{Overall findings about the fate and behaviour of HFO}

The below descriptions summarise the general findings about the fate and behaviour of HFO.

Furthermore, as part of this project, new oil weathering model predictions were made for six selected HFOs at $2{ }^{\circ} \mathrm{C}$ and a wind speed of $10 \mathrm{~m} / \mathrm{s}$ to reflect Arctic water conditions. In a previous study from 2007, the oil weathering predictions were conducted at $15^{\circ} \mathrm{C}$ and $10 \mathrm{~m} / \mathrm{s}$ wind speed (see Moldestad et al. 2007). The six HFOs from the SINTEF oil database used in the new predictions are similar to those employed in the 2007 predictions.

The new predictions were made using the SINTEF Oil Weathering Model (OWM) version 4.0 beta, 2010. This is a newer version than that applied by Moldestad et al. (2.0, 2002). However, the use of the updated model is expected to produce only minor differences. The weathering behaviour of the six HFOs included evaporative loss, water content, emulsion viscosities and pour point as shown in Figure 5 for both predictions. A general discussion of the predictions is found below. 


\subsubsection{Density}

The density of HFO typically lies within the range $0.92-1.02 \mathrm{~kg} / \mathrm{L}$ and it is thus expected to float in seawater but may sink in brackish or fresh water (O'Brien 2002). The density is found to increase due to weathering, for example as a function of evaporation.

\subsubsection{Pour point}

Examples of how the pour point increases with weathering time are shown in Figure 5 for different HFO types. If the original crude oil is rich in waxes or asphaltenes, then the derived HFO will also be rich in waxes or asphaltenes. A high content of waxes results in a high pour point (Moldestad and Resby 2001). A high pour point reduces the spreading and thereby also the evaporation of the oil.

The pour point predictions shown in Figure 5 highlight that the cold conditions $\left(2^{\circ} \mathrm{C}\right)$ result in a slightly delayed increase in pour point compared with the warmer scenario $\left(15^{\circ} \mathrm{C}\right)$. This is expectedly linked to the reduced evaporation also found in the $2{ }^{\circ} \mathrm{C}$ scenario.

\subsubsection{Viscosity}

The viscosity of HFO will increase more slowly than that of, for instance, crude oils from the North Sea. This is due to the initially high viscosity of the HFO, which hampers the creation of stable water-in-oil (w/o) emulsions and results in relatively large "waterpockets" rather than in small water droplets in the oil (Moldestad and Resby 2001). Examples of the increase in viscosity for the six different HFOs are shown in Figure 5. The trend is similar in the two scenarios $\left(2^{\circ} \mathrm{C}\right.$ and $\left.15^{\circ}\right)$; however, the viscosities are somewhat higher for the colder Arctic scenario.

\subsubsection{Evaporation}

In relation to $\mathrm{HFO}$, it is most likely that parts of the distillate in the mixture will evaporate, whereas the change in the residual fuel part will be limited; thus, the evaporation is determined by the properties and content of the distillate. Examples of evaporation of the six different HFOs are shown in Figure 5 . Compared with light distillates and crude oils, the evaporative loss is low (in most cases $<5-10 \%$ ) due to the low content of VOC compounds. The $2{ }^{\circ} \mathrm{C}$ model predictions show that at such low air temperatures, evaporation will be less than $10 \%$ for most of the oils included in the simulations.

Also, spreading will influence evaporation; reduced spreading will result in reduced evaporation. Spreading is described in more detail below. 


\subsubsection{Natural dispersion}

In general, natural dispersion is minor for surface oil spills of HFO or MGO/diesel. This is due to the low content of BTEX (Benzene, tolvene, ethylbenzene, and xylene) compounds, which are those most likely also to evaporate before the dispersion starts. Under very bad weather conditions, however, natural dispersion of water-soluble compounds might occur.

\subsubsection{Spreading}

In general, oil tends to spread due to the specific surface tension (Afenyo et al. 2016). However, HFO spreads less due to its high viscosity and density and if the pour point is above the temperature of the ambient environment $\left(10-15^{\circ} \mathrm{C}\right.$ higher than the water temperature). Instead HFO spills will break into small masses and have a tar-like consistency that can easily stick to exposed substrates, further complicating the cleanup of the HFO (PAME II 2016) (more details in Chapter 8).

At a wind exposure of $>5 \mathrm{~m} / \mathrm{s}$, oil slicks normally disperse into smaller droplets $(1-1000 \mu \mathrm{m})$. However, the high HFO viscosity and density create large oil lumps of several centimetres in diameter (Moldestad and Resby 2001).

From an experimental release of HFO it was found that slick thicknesses of $0.5^{-}$ $1 \mathrm{~cm}$ were generated (Fiocco et al. $1999 \mathrm{~A}$ and B), which is much thicker than for oil in general where - as a rule of thumb $-90 \%$ of the oil slick has a thickness of 1-5 $\mathrm{mm}$, the remaining part being a sheen with a thickness $<1 \mu \mathrm{m}$. In the experimental spill, after some hours of weathering, the HFO consisted only of thick emulsions and no sheens were found around the slick (Moldestad and Resby 2001).

\subsubsection{Water-in-oil emulsion}

As opposite to most marine distillate fuel HFO can take up large amounts of water, up to $70-80 \%$, which is a 5 times increase in the volume (see Figure 5). For three of the six tested oils in the predictions (Figure 5), the water content was significantly reduced in the $2{ }^{\circ} \mathrm{C}$ prediction compared with the prediction at $15^{\circ} \mathrm{C}$. This difference might be due to increased viscosity of these HFO types and/or to solidification (high wax content), with lower water uptake as a result. For the three other HFOs, the water uptake was relatively similar for the two scenarios. The typical range of the water content was 20-50\%. Water-in-oil emulsification occur slowly, over several hours, producing increased volumes of highly viscous emulsions. These emulsions influence the effectiveness of all the response measures and create a challenge relative to storage capacity. 
Figure 5: Evaporation, pour point, water content and emulsion viscosity for 6 IFOs at sea at $15^{\circ} \mathrm{C}$ and $10 \mathrm{~m} / \mathrm{s}$ (left side figures) and at $2{ }^{\circ} \mathrm{C}$ and $10 \mathrm{~m} / \mathrm{s}$ for the same 6 IFOs (right side figures)
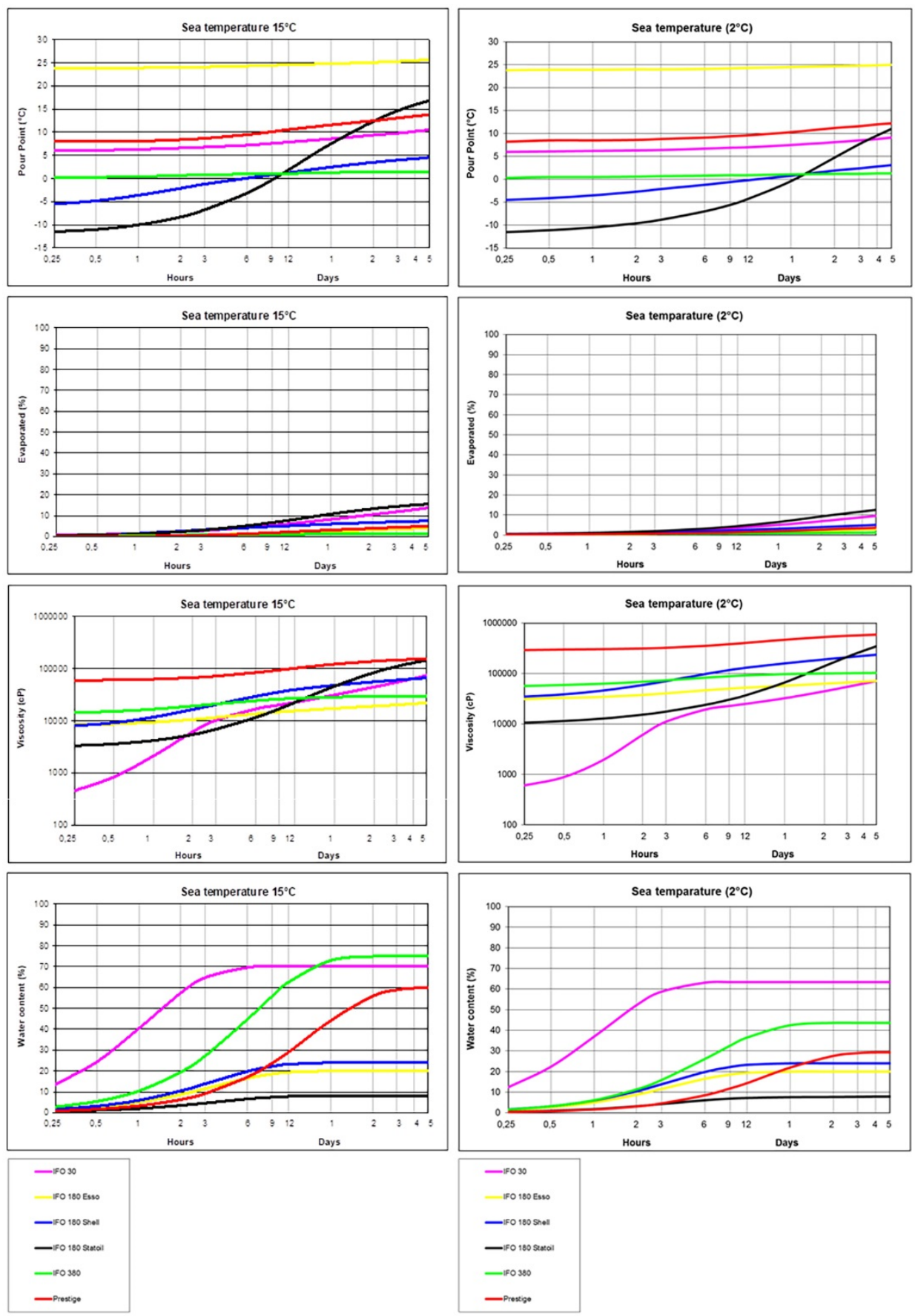

Source: From Moldestad et al. (2007). 


\section{Incidents involving HFO in cold environments}

This review of the fate and behaviour of HFO in cold environments is mostly based on the SINTEF laboratory weathering studies. The literature review (see Appendix 1) showed that - apart from these studies - limited literature, and thus knowledge, is available about the fate of HFO in the Arctic (or in cold environments). As for the existing literature on oil spills, for example the Prestige incident, the prevailing conditions do not qualify as Arctic/cold. However, four oil spill accidents, all involving HFOs, have occurred over the past 15 years in southern Norway, of which three took place during winter.

In Appendix 2, a list of incidents above latitude of $55^{\circ} \mathrm{N}$ involving HFO is given. In the following, the Prestige and the four Norwegian incidents are described.

\subsection{Prestige}

The Prestige incident off the coast of Galicia, Spain, took place at an estimated water temperature of around $12-15^{\circ} \mathrm{C}$, which cannot be considered as Arctic. Nevertheless, the experiences from this study are included in our review as the weathering and fate of the oil are relatively well documented.

Samples taken at different times during the recovery of the oil from the Prestige were analysed by SINTEF (Moldestad and Leirvik 2003). The original oil can be characterised as IFO650, which has a non-Newtonian behaviour, i.e. the viscosity of the oil is dependent on the shear rate. This behaviour was found at both $5^{\circ} \mathrm{C}$ (largest shear dependence) and $15^{\circ} \mathrm{C}$ (Moldestad and Leirvik 2003), viscosity thus will increase at low temperatures.

After three months of weathering at sea, the oil had a viscosity of approximately $300,000 \mathrm{cP}$ at $10 \mathrm{~s}-1$ and a water content of $60 \%$. Elasticity (gel strength) measurements showed enhanced elasticity with increasing weathering time, resulting in a more "rubber-like" emulsion after three months, whereas the emulsions generated after a few days were still running (Figure 6) (Moldestad and Leirvik 2003). During the recovery of the oil, the responders faced a strong challenge in recovering the highly viscous and emulsified oil, and the oil will expectedly be even more demanding to handle at lower water temperatures (Moldestad and Leirvik [2003]). 
Figure 6: Example of Prestige oil after 61 days of weathering at sea. The oil was highly viscous, stiff and solid

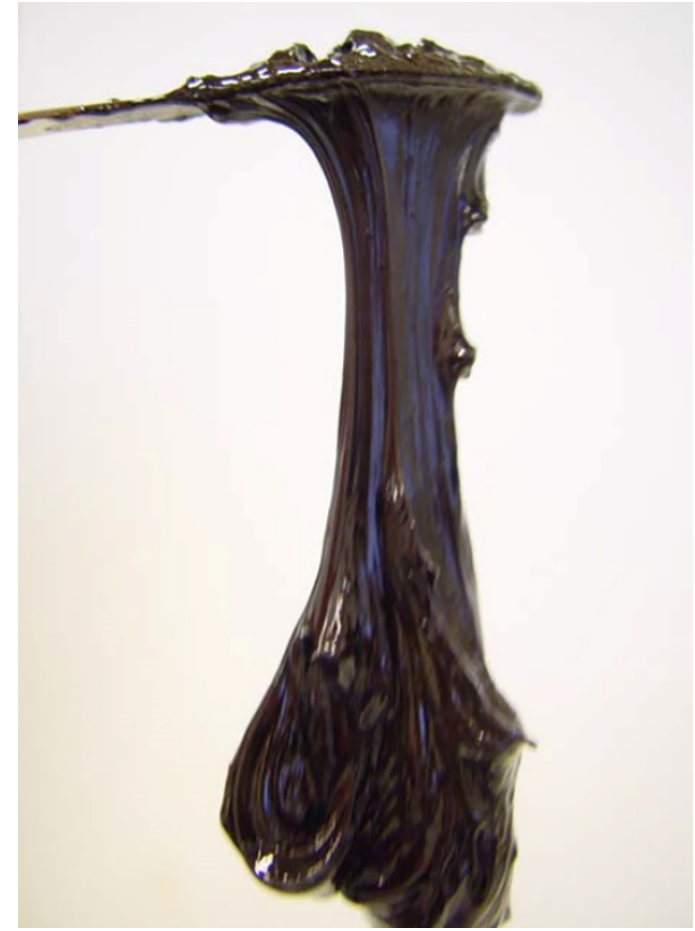

Source: Photo from Moldestad and Leirvik (2003).

The pour point for the Prestige oil was $3{ }^{\circ} \mathrm{C}$. This implies that in cold environments where water temperatures rarely exceed $3-5^{\circ} \mathrm{C}$ (Wegeberg et al. 2018), the oil is likely to become solid. Solidification is most often seen when the pour point is $10-15^{\circ} \mathrm{C}$ above the seawater temperature.

Evaporation of the Prestige oil was found to be low $(<5 \%)$, even after 88 days of weathering at sea. The low evaporation of HFOs can be explained by an initially low content of volatile compounds in the parent oil and the tendency of the oil to generate thick oil slicks due to the low pour point and high viscosity that prevent evaporation (Moldestad and Leirvik 2003).

The weathered Prestige oil showed an increase in density up to $1.025 \mathrm{~kg} / \mathrm{L}$; however, the emulsion was still found to be buoyant in saltwater $(\rho>1.025 \mathrm{~kg} / \mathrm{L})$ (Moldestad and Leirvik 2003).

\subsection{Four Norwegian incidents}

In southern Norway over the past fifteen years, four relatively large oil spill incidents, all involving HFOs, have occurred.

The Rocknes incident took place on 19 January 2004 near Bergen, Norway. The vessel contained 426 tons of $\mathrm{IFO}_{3} 80$ and 58 tons of marine diesel as well as lubricating oil. Large amounts entered the environment and reached the coastline. 
In total, 226 tons of oil were removed from the sea. The environmental studies of the oil fate showed gradual degradation of the oil by removal of the lightest compounds first (Boitsov et al. 2012).

The Server incident occurred on 12 January 2007 in Fedje, Norway. The vessel contained 676 tons of oil, mostly IFO180, of which 139 tons were removed from the sea and 149 tons were removed from or remained in the ship. The remaining oil entered the environment and spread quickly, polluting in total 40 kilometre of shoreline (Boitsov et al. 2012). Due to very bad weather conditions during the spill, precipitating the degradation, it was assumed that a large portion of the oil was dispersed/entrained into the water column. However, low concentrations of oil were found in the water column (Boitsov et al. 2012).

The Full City incident occurred on 31 July 2009 near Langesund, Southern Norway. The ship contained 1154 tons of IFO 180 and 120 tons of marine diesel. Approximately 293 tons of $\mathrm{IFO}_{1} 80$ were spilled. 840 tons were removed from the ship, while 74 tons were collected from the shore and 28 tons from the sea. In total, 75 kilometre shoreline were contaminated. Just after the spill, elevated concentrations of NPDs (naphthalene, phenanthrene, dibenzothiophene including their $\mathrm{C}_{1}-\mathrm{C}_{3}$ alkyl homologues) and THCs (total hydrocarbons) were found in the water column but only near the wreck (Boitsov et al. 2012).

The Godafoss incident happened on 17 February 2011 near Hvaler Islands off the southeast coast of Norway. The vessel contained 555.5 tons of IFO380, of which 112 were released into the environment. Approximately 55 tons were recovered from the sea, a relatively high amount, due to stable weather conditions; however, the cold temperatures and ice challenged the recovery. In total, 4 kilometre of shoreline were contaminated (Boitsov et al. 2012).

The overall findings of the four incidents were that the water surface, the upper parts of the water column as well as the coastline are the most vulnerable parts of the environment (Boitsov et al. 2012). 


\section{Biodegradation of HFO at cold temperatures}

This part of the review aims at collecting and assessing current knowledge about the biodegradation of HFO at cold temperatures with primary focus on finding peerreviewed research involving use of HFO or other petroleum hydrocarbons containing heavy fractions. Since only a limited number of studies exist with particular focus on HFO or heavier petroleum products, some studies using crude oils or lighter fraction petroleum hydrocarbons were included.

In the literature review, studies conducted at temperatures $<15^{\circ} \mathrm{C}$ were preferred, but investigations at higher temperatures were also included. Experimental studies of HFO at cold temperatures proved difficult to find.

Petroleum hydrocarbon biodegradation studies have been carried out on different fractions of the HFO and in different matrices, including water, sediment, soil and seaice. Most studies were conducted in seawater, followed by soil, sediment and ice. Tables showing all the studies included in our review are presented in Appendix 3. A list of keywords used in the search strategy for the literature review is given in Appendix 1.

Overview of published experimental setups:

Most of the biodegradation studies were small-scale laboratory (microcosm) experiments, although the soil, sediment and ice-water experiments occasionally included mesocosm or field studies. Some of the studies were conducted using weathered contaminated samples and others using samples spiked with petroleum hydrocarbons. Most experiments were carried out under oxic conditions, but some sediment and soil experiments were undertaken also under anoxic conditions.

Commonly used methods for chemical analysis:

The most commonly used method for chemical analysis of petroleum hydrocarbons is gas chromatography combined with mass spectrophotometry (GCMS) and/or a flame ionization detector (GC-FID). With GC-FID, hydrocarbons are commonly measured as total petroleum hydrocarbons, including all hydrocarbon fractions, or separately as different fractions, for example middle fractions ( $\left.\mathrm{C}_{10-21}\right)$ and heavy fractions ( $\mathrm{C}_{21}-\mathrm{C}_{40} \mathrm{O}$ ). For detection of individual compounds, such as specific polycyclic aromatic hydrocarbons (PAHs) or phytane and hopane, GC-MS is required.

Methods used for measurement of biodegradation:

Various highly different methods are used for measuring the biodegradation ratio of hydrocarbons. The most commonly used method is to measure the disappearance of hydrocarbons during the test using GC-MS or GC-FID, followed by calculation of mass balance as an indication of the biodegradation percentage between start and end without any intermediate time points. In some cases, biodegradation percentages are reported for individual hydrocarbon fractions, but more often they are indicated as a 
range of different fractions (e.g. Björklöf et al. 2008, Kristensen et al. 2015) or include all fractions (total petroleum hydrocarbons) (e.g. Cai et al. 2016, Yu et al. 2011). The biodegradation rate can be calculated by accounting for the duration of the experiment and the concentration of petroleum hydrocarbons in the environmental compartment in question. For true kinetic parameters, several time points are needed. The biodegradation may also be reported as half-lives or as ratios between the $\mathrm{HC}$ fractions and chemical biomarkers, such as phytane (Gerdes et al. 2006) or hopane (e.g. Gallego et al. 2006, Fernandes-Alvares et al. 2006).

Methods used for microbial analyses:

Microbes are known to be the key component in petroleum hydrocarbon degradation. Most environmental bacteria cannot be cultivated, and the most frequently used methods for identification of bacteria present in microbial communities in environmental samples are molecular such as DGGE, T-RFLP, 16s DNA and RNA sequencing. However, the taxonomy of bacteria does usually not provide sufficient evidence for their oil biodegradation capacity because the metabolic capacity may vary within the same genera. Therefore, much emphasis was placed on identifying and enumerating genes that encode for enzymes involved in the biodegradation of petroleum hydrocarbons using the functional gene qPCR. The abundance of oildegrading genes has been found to correlate with the oil biodegradation rates (Salminen et al. 2008).

For enumeration of bacteria, microscopy and cell counting are used. Cultivable oildegrading bacteria can also be quantified using most probable number (MPN) techniques on oil-containing media.

\subsection{Overview of biodegradation ranges in different compartments}

An overview of the studies included in this review is found in Table 3. Due to the very diverse reporting of the results, it is difficult to present them in a comparable way. The studies were divided into four different environmental compartments relative to temperature. The studies on HFO were grouped separately. Find more details on the different compartments below. 
Table 3: Overview of biodegradation ranges in different environmental compartments

\begin{tabular}{|c|c|c|c|c|c|}
\hline Compartment & Fuel type & Temperature & $\begin{array}{l}\text { Number } \\
\text { of studies }\end{array}$ & $\begin{array}{r}\text { Experiment } \\
\text { duration }\end{array}$ & Degradation range \\
\hline \multirow[t]{4}{*}{ Seawater } & \multirow[t]{2}{*}{ Heavy/HFO } & $<15^{\circ} \mathrm{C}$ & 2 & $7-46 d$ & $\begin{array}{r}65-71 \%, 9.9 \text { d half-lives } \\
\text { (alkanes) }\end{array}$ \\
\hline & & $>15^{\circ} \mathrm{C}$ & 5 & $21-42 d$ & $30-93.5 \%$ \\
\hline & \multirow[t]{2}{*}{ Light/Medium } & $<15^{\circ} \mathrm{C}$ & 14 & $15-77 \mathrm{~d}$ & $\begin{array}{r}18-90 \%, 2.2-3.5 \mathrm{~d} \text { half-lives } \\
\text { (alkanes) }\end{array}$ \\
\hline & & $>15^{\circ} \mathrm{C}$ & 1 & $28 d$ & $28 \%$ \\
\hline \multirow[t]{4}{*}{ Sediment } & \multirow[t]{2}{*}{ Heavy/HFO } & $<15^{\circ} \mathrm{C}$ & 3 & $70-220 d$ & $38-96 \%$ \\
\hline & & $>15^{\circ} \mathrm{C}$ & 3 & $240-730 \mathrm{~d}$ & $35-100 \%$ \\
\hline & \multirow[t]{2}{*}{ Light/Medium } & $<15^{\circ} \mathrm{C}$ & 2 & $77-119 d$ & $\begin{array}{r}\text { 51-59\% anoxic sediment, Fe- } \\
\text { Mn concretions: } 35-80 \% \\
\text { oxic: } 1-18 \mathrm{mg} \mathrm{kg}^{-1} \mathrm{~d}-1 \text {, } \\
\text { anoxic: } 1-9 \mathrm{mg} \mathrm{kg}^{-1} \mathrm{~d}^{-1}, 46 \% \\
\text { sediment }\end{array}$ \\
\hline & & $>15^{\circ} \mathrm{C}$ & - & - & 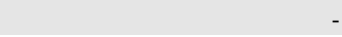 \\
\hline \multirow[t]{4}{*}{ Soil } & \multirow[t]{2}{*}{ Heavy/HFO } & $<15^{\circ} \mathrm{C}$ & 3 & $120-360 \mathrm{~d}$ & $\begin{array}{r}31-44 \% \\
\text { oxic: } 2-23 \mathrm{mg} \mathrm{TPH} \mathrm{kg} \mathrm{d}^{-1} \\
\text { anoxic: } 1.12 \mathrm{mg} \mathrm{TPH} \mathrm{kg}^{-1} \mathrm{~d}^{-1}\end{array}$ \\
\hline & & $>15^{\circ} \mathrm{C}$ & 1 & $90 \mathrm{~d}$ & $20-78 \%$ \\
\hline & \multirow[t]{2}{*}{ Light/Medium } & $<15^{\circ} \mathrm{C}$ & 3 & $60-660 \mathrm{~d}$ & $70-95 \%$ \\
\hline & & $>15^{\circ} \mathrm{C}$ & - & - & - \\
\hline \multirow[t]{4}{*}{ Sea-ice } & \multirow[t]{2}{*}{ Heavy/HFO } & $<15^{\circ} \mathrm{C}$ & - & - & - \\
\hline & & $>15^{\circ} \mathrm{C}$ & - & - & - \\
\hline & \multirow[t]{2}{*}{ Light/Medium } & $<15^{\circ} \mathrm{C}$ & $8 *$ & $30 \mathrm{~d}$ to $>2 \mathrm{yr}$ & $1.7-5.4 \%$ (hexadecane) \\
\hline & & $>15^{\circ} \mathrm{C}$ & - & - & ( \\
\hline
\end{tabular}

Note: *Many of the studies conducted on sea-ice did not provide numerical estimations of biodegradation rates or percentages.

\subsection{Biodegradation in seawater}

Many published studies are available on oil degradation at cold temperatures, but there is a knowledge gap regarding the biodegradation of HFO or heavy crude oils. From the research surveyed for this review (presented in Table 3), only two studies using HFO (Brown et al. 2016) or heavy crude oil (Venosa 2007) at cold temperatures could be identified. See Appendix 3, Table 11 for full study details.

Brown et al. (2016) investigated the biodegradation of IFO180 in filtered seawater in a 7-day microcosm experiment at $0^{\circ} \mathrm{C}$ and $5{ }^{\circ} \mathrm{C}$. The biodegradation percentages for IFO 180 were $71 \%\left(0^{\circ} \mathrm{C}\right)$ and $65 \%\left(5^{\circ} \mathrm{C}\right)$. The study by Venosa \& Holder (2007) was a microcosm experiment using heavy crude oil (Prudhoe Bay) at $5{ }^{\circ} \mathrm{C}$ for 46 days. Biodegradation rates in this research were reported as alkane half-lives: 4.6 days (with dispersant) and 9.9 days (without dispersant). Because of the different methods and units used in measuring biodegradation, it is difficult to compare degradation estimates between the different studies.

At higher temperatures $\left(17-25^{\circ} \mathrm{C}\right)$, total hydrocarbon degradation percentages for HFO ranged between $30 \%$ (Hozumi et al. 2000) to $94 \%$ (Germano de Almeida et al. 2017).

In the studies conducted with medium petroleum fractions, the total petroleum hydrocarbon degradation percentages at cold temperatures $\left(-1\right.$ to $\left.10^{\circ} \mathrm{C}\right)$ varied from 
$46 \%$ (McFarlin et al. 2014) to $88 \%$ (Prince et al. 2013). In the study by Kadali et al. (2013) conducted at higher temperatures, the biodegradation percentages ranged between 16 and $28 \%$.

Biodegradation studies with lighter fractions were carried out at temperatures between -1.7 and $15^{\circ} \mathrm{C}$ and, overall, they showed higher degradation percentages than

heavier fractions. However, the experimental methods used for measuring biodegradation and duration varied markedly, making it difficult to compare the biodegradation results between studies. The degradation percentages for the different hydrocarbon fractions ranged from $0.1 \%$ (Kristensen et al. 2015) up to 90\% (Lin et al. 2009) for experiments with a duration $<28 d$; for longer studies (duration $>28 d$ ) the degradation percentages ranged between $0.1 \%$ (Kristensen et al. 2015) and $100 \%$ (Brakstad and Bonaunet 2006).

In order to normalise the data from the different studies, we calculated the daily degradation rates using the initial concentrations, degradation percentages and test durations reported in the studies, assuming a linear degradation. This is a very rough normalisation, because at lower concentrations the oil degradation is most often a 1st order degradation. However, this was the best way to estimate and compare the degradations rates. The comparison of the different degradation rates is presented in Figure 7. 
Figure 7: Biodegradation rates in seawater normalised by calculation as $\mu \mathrm{g}$ petroleum hydrocarbon/L per day

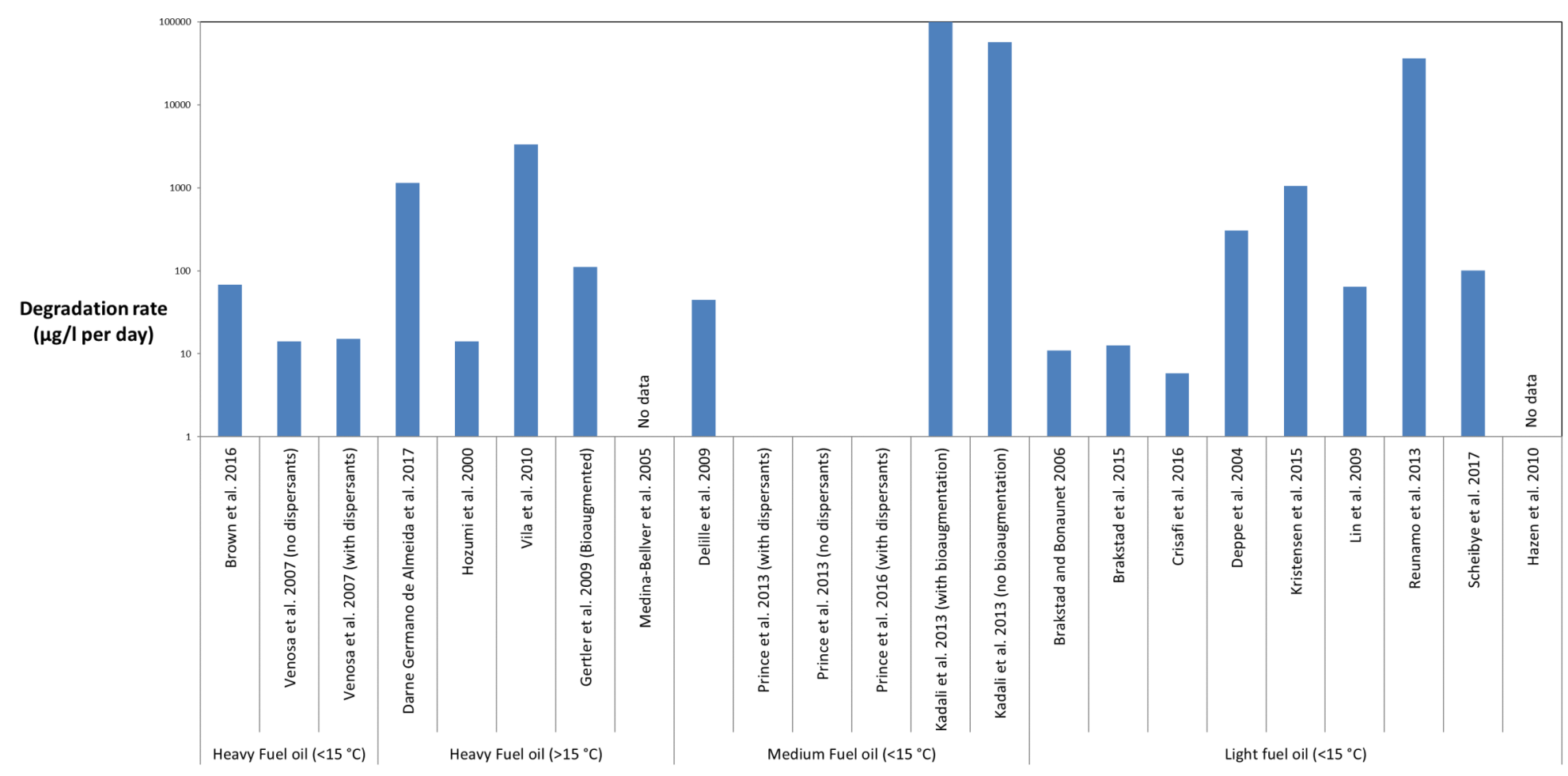

In some studies, insufficiency of data did not allow calculation of daily degradation results. 
The comparison showed that HFO was degraded at a lower speed at temperatures below $15^{\circ} \mathrm{C}$ than at temperatures above $15^{\circ} \mathrm{C}$. Sometimes, at temperatures below $15^{\circ} \mathrm{C}$, light crude oils were degraded at similar speed, and HFO and refined products such as diesel were degraded at higher speeds.

\subsection{Biodegradation in the sediment compartment}

Not much is known about heavy petroleum biodegradation in the sediment. The few studies available relate to heavy petroleum fractions recorded in microcosm and mesocosm experiments and at field scale (Table 3). See Appendix 3, Table 12 for full details of the studies.

Some knowledge on what could be considered as heavy petroleum products exists on such as $\mathrm{IFO}_{30}$ (Garrett et al. 2003) and beach/sediment samples containing weathered oil from the Prestige oil spill (Gallego et al. 2006, Fernadez-Alvares et al. 2006, Jimenez et al. 2007). These studies were generally long, lasting from 90 to 220 days. Since the studies were conducted at different scales (field and mesocosm), the temperatures during the experiments varied. The biodegradation in the studies conducted at cold $\left(3.8-6^{\circ} \mathrm{C}\right.$ ) temperatures varied from $16 \%$ (total hydrocarbons) (Hua 2006) to $38-96 \%$ (compared with hopane) (Jimenez et al. 2007). At $20^{\circ} \mathrm{C}$, a crude oil degradation percentage of $20 \%$ was obtained and could be enhanced to up to $97 \%$ removal using aeration of the sediment (Genovese et al. 2014). However, the oil was analysed by TERHC (total extracted and resolved hydrocarbons) fraction.

A comparison of normalised degradation rates in sediment is presented in Figure 8. Daily degradation rates were calculated using the initial concentrations, degradation rates and test durations reported in the studies.

Figure 8: Biodegradation rates in sediment normalised by calculation as $\mathrm{mg}$ petroleum hydrocarbons/ $\mathrm{kg} \mathrm{dw}$ per day

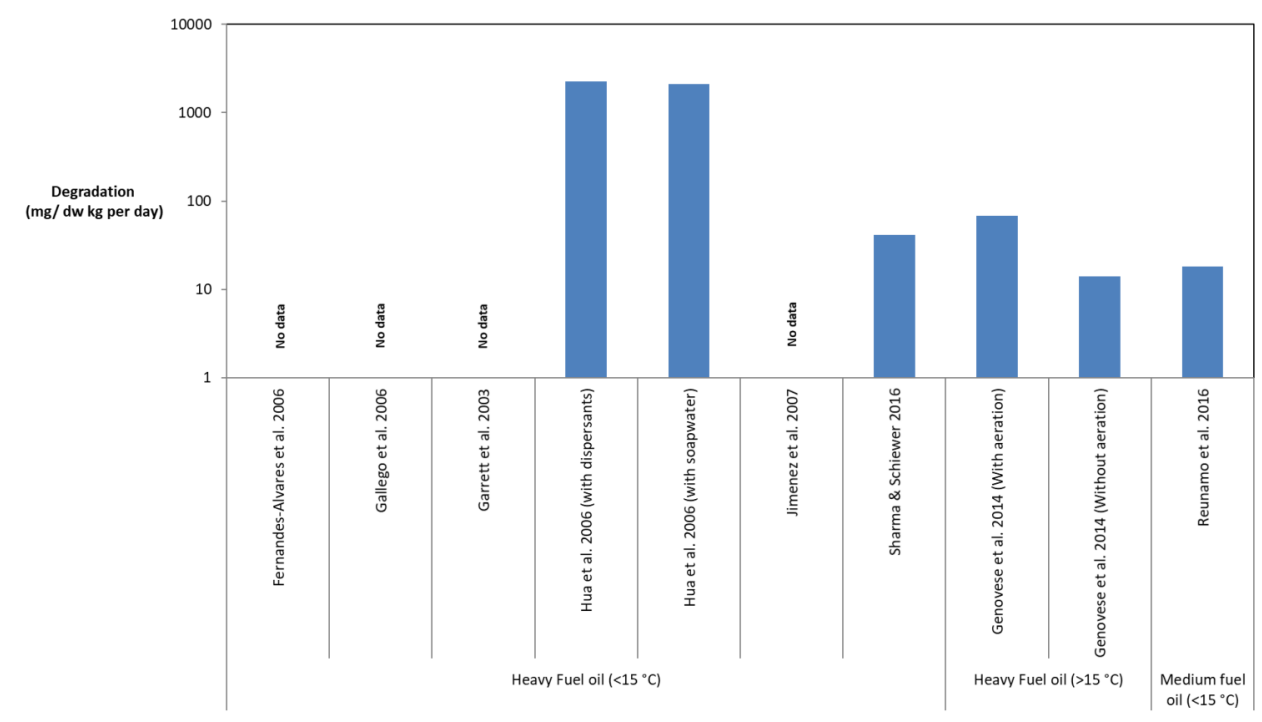

Note: In some studies, insufficiency of data did not allow calculation of daily degradation results. 
No data were available on the degradation rates of HFO in sediments at low temperatures. However, the experiments by Hua (2006) using dispersant and soap water in the sediment resulted in higher calculated degradation rates than for $\mathrm{HFO}$ at temperatures above $15^{\circ} \mathrm{C}$.

\subsection{Biodegradation in the soil compartment}

Petroleum hydrocarbon degradation in soil has been investigated at various scales including microcosm, mesocosm and pilot-scale studies (Table 3). See Appendix 3, Table 13 for full details of the studies. Research into heavy petroleum products has mostly been carried out at temperatures above $\left(\mathrm{ca} .20^{\circ} \mathrm{C}\right.$ ) the Arctic average, and there is a clear gap of knowledge regarding HFO degradation at cold temperatures. The durations of the soil experiments varied between 3 and 12 months.

The HFO biodegradation percentages commonly reported as TPH (total petroleum hydrocarbons) in the literature range between 20 and $54 \%$ (Cai et al. 2016). For light fuel oil at lower temperatures, biodegradation percentages of 30-78\% have been observed (Björklöf et al. 2008, Wang et al. 2016), but the time frame is considerably longer $(60-365 \mathrm{~d})$. Degradation of light fuel oil has also been observed under anoxic conditions (Björklöf et al. 2008, Salminen et al. 2004) with rates of 1-12 mg TPH kg-1 d-1, which were around $50 \%$ compared with the rates of $2-34 \mathrm{mg} \mathrm{TPH} \mathrm{kg-1} \mathrm{d-1under} \mathrm{oxic} \mathrm{conditions.} \mathrm{A}$ comparison of degradation rates per day in soil is presented in Figure 9 . Daily degradation rates were calculated using the initial concentrations, degradation rates and test durations reported in the studies.

Figure 9: Biodegradation rates in soil normalised by calculation as $\mu \mathrm{g}$ petroleum hydrocarbon $/ \mathrm{kg} \mathrm{dw}$ per day

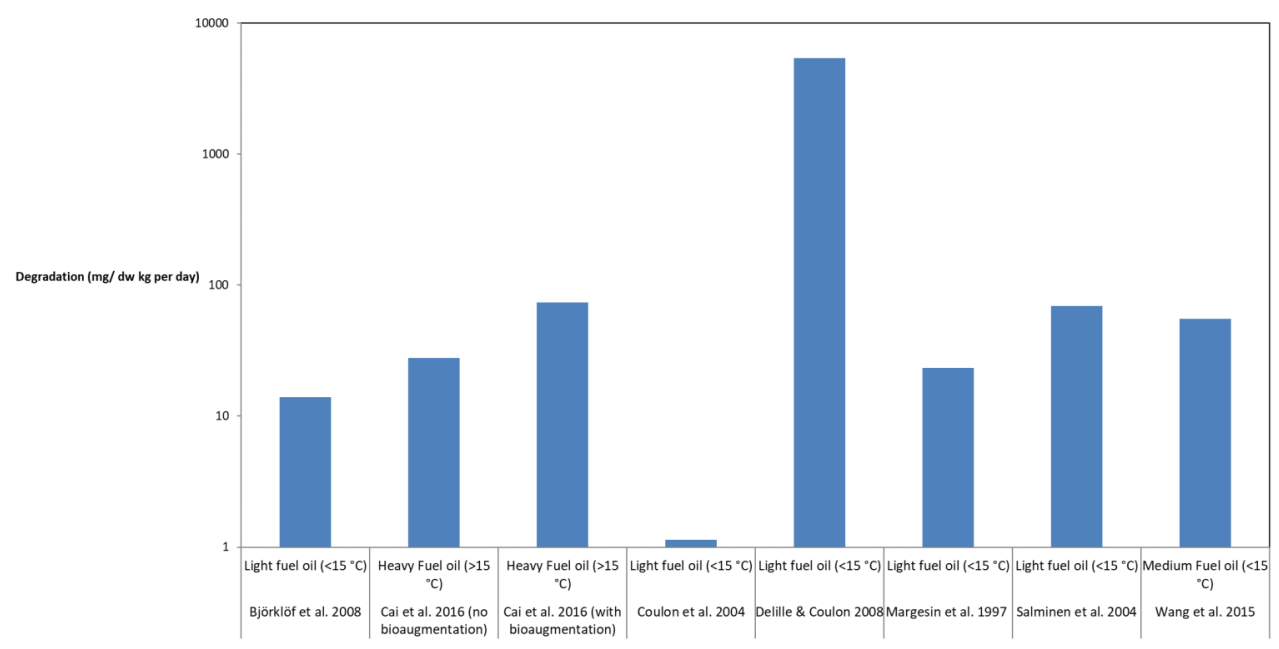


The comparison showed that heavy fuel (heavy crude oil) was degraded at high temperatures in soil and at rates similar to those of light and medium fuel at low temperatures.

\subsection{Biodegradation in the ice compartment}

No research appeared on biodegradation of heavy petroleum products in sea ice, but results were obtained on studies of medium and lighter petroleum fractions mostly at mesocosm and field scale (Table 3). See Appendix 3, Table 14 for full details of the studies.

Two studies were conducted in microcosms, but the majority of the obtained studies were conducted as either mesocosm or field studies. Some of the experiments were carried out using melted water from ice cores. In many studies on sea-ice, hydrocarbon degradation is described qualitatively, and no numeric estimations of the degradation are given. The duration of the experiments was generally long, lasting from three months to more than three years due to the low degradation in the ice.

\subsection{Overall findings of biodegradation}

Only a handful of biodegradation studies have been conducted using HFO at cold temperatures (Table 3). Biodegradation of crude oils and lighter petroleum products has been observed in all matrices (seawater, sediment, soil and ice) even at cold temperatures. The overall finding is that degradation is reduced at cold temperatures. The degradation rate is limited by the amount of oil that can dissolve in the water phase. The degradation of HFO is generally slower in seawater $(65-71 \%$ at cold temperatures) compared with that of medium and light petroleum products (18-90\% at cold temperatures). Degradation under anoxic conditions in soils and sediments occurs at a rate half of that under oxic conditions. However, the great variability in experimental duration and biodegradation measurement methodologies renders a comparison of the degradation rates between different studies difficult.

\subsection{Potential for biodegradation of HFO in the marine environment}

For biodegradation to occur, spilled oil has to enter the water column and/or sediment to become exposed to oil-degrading bacteria. Only a minor part of the oil will be degraded at the oil-water interface. Only if oil, spilled on the water surface, is stranding, direct exposure to bacteria in the sand, on rocks or in the soil on the coast will occur. In general, the abundance of bacteria in the water column is much lower than in sediments, but substantial biodegradation (as per cent of added oil) in the water column has been observed. The experiments reported in this review have been carried 
out at a wide range of concentrations of added oil, from around $2 \mu \mathrm{g}$ (petroleum hydrocarbons $\mathrm{C}_{10}-\mathrm{C}_{40}$ ) L-1 to $10000000 \mu \mathrm{g} \mathrm{L}-1$ mainly in laboratory scale experiments. At the highest concentrations, the oil is present in free phase and is as such not soluble (or accommodated) in the water phase and is therefore not bioavailable. In the weathering studies (Chapter 4 ), very low dispersion has generally been found (e.g. $5 \%$ of an $\mathrm{IFO}_{3} 80$ at $0-5{ }^{\circ} \mathrm{C}$ and a wind speed of $10 \mathrm{~m} / \mathrm{s}$ ), and increased viscosity and pour point seem to cause the oil to remain on the water surface. This means that only around $5 \%$ of the oil will enter the water column and be exposed to biodegradation. Accordingly, experiments with very high concentrations of oil are irrelevant for biodegradation studies of HFO as such situations will only occur if the oil is, for example, chemically dispersed. The remaining oil may enter the water column later as sticky clumps that are only bioavailable on the surface. Where chemical dispersant are used, higher amounts of oil can enter the water column and thus enhance the biodegradation potential, but at the same time, also higher concentrations of oil will be bioavailable for biota in the water column.

\subsubsection{Enhancing the natural biodegradation potential}

Speeding up natural biodegradation in bioremediation applications is usually achieved by changing the conditions in the environment by addition of nutrients, surfactants or dispersants, or oxygen or oxidising compounds. Enhanced biodegradation of heavy bunker fuel oil in sediment was observed by Hua (2006) in experiments with addition of dispersants and soap water. Prince et al. (2013) also found enhanced biodegradation of crude oil in seawater using dispersants at low temperatures. Brakstad et al. (2015) showed that the oil droplet size distribution produced when dispersing crude oil is very critical for the degradation rate of the individual oil components and that the degradation rate decreases dramatically if the oil droplet becomes larger than 100 microns. Enhancing the biodegradation potential by addition of pre-grown microbes (bioaugmentation) in pure or mixed cultures is also an option. So far, no publications have been found describing bioaugmentation of HFO at low temperatures. However, Gerdes et al. (2006) found that cold-adapted isolated bacteria could enhance the biodegradation of crude oil when added to sea ice, and Kadali et al. (2012) also recorded enhanced biodegradation of crude oil in seawater with bioaugmentation.

As the biodegradation of oil compounds is limited by the amount of oil that can be accommodated and dissolved in the seawater, the use of dispersant could enhance the biodegradation potential. As HFO is only partly chemically dispersible, this overall response strategy may still leave floating or sinking oil emulsions. Combined use of dispersants with addition of microbial cultures will enhance the biodegradation the most, but more research into microbial addition and development of technology for its application at large scale are needed. 


\section{Environmental impacts from marine HFO spills}

Environmental impacts of oil spill in the sea are closely related to the physical properties and chemical composition of the oil as well as the changes caused by the weathering of the oil (as described in Chapters 4-6). Overall, the available fate and weathering data on HFO indicate that the major environmental concerns regarding HFO spills are related to the potential effects of HFO on the water surface. This is a result of the relatively low content of water-soluble and volatile components generally found in HFOs compared with, for example, marine diesel and/or crude oil. In addition to this, the low natural dispersion of HFO into the water column adds to an expected relatively low exposure of the organisms to contamination in the water column in case of an HFO spill.

The ability to form stable emulsions with a typical water content of $20-50 \%$ also contributes to the stabilisation of HFO on the water surface. Hence, there is a high risk of smothering seabirds and other surface living species as well as polluting the coastline. It is well known that seabirds are very vulnerable to oil spills as they spend their non-breeding season at sea, relying on feathers for flight, insulation and buoyancy (Stephenson 1997).

There is a potential, however, for submerging or sinking of HFO due to its higher density as a result of weathering and/or adsorption of inorganic particulate matter in the sea. A sub-surface HFO slick was observed in connection with the Baltic Carrier oil spill accident in low saline Danish waters in 2001, hampering recovery of the oil (Storstrøms Amt, pers. comm.). Eventually, though, the oil beached.

The longest persistence of an oil spill has been found in soft sediments and on shorelines protected against strong wind and waves. In general, rocky headlands are quickly cleansed by wave and tidal actions. Oil contamination of sediments can be very long lasting and long-term effects on benthic organisms have been seen in several cases (Shigenaka 2014). It has been reported, in connection with oil beaching on sheltered rocky coasts, that the intertidal macroalgal cover was lost due to oil smothering and/or coastline cleaning efforts (e.g., Shigenaka 2014, Boitsov et al. 2012). However, relatively few studies are available providing data on the effects of oil pollution on macroalgae (e.g., Stepaniyan 2008, Stepanyan \& Voskoboinikov 2006). Smothering effects of HFO under Arctic conditions were studied by Wegeberg et al. (2017) who found that the HFO was washed off the macroalgae surface after 1-2 weeks and that the oil may affect the photosynthetic activity, having both an inhibiting and stimulating effect over time.

Environmental scientists and oil spill response authorities may be interested in different properties of oil and use different parameters to describe the properties and 
concentrations of the oil in the environment. While oil spill response authorities are interested in the viscosity, pour point and water content of the oil with respect to the feasibility of collecting it from the water surface with brushes and skimmers, the focus of environmental scientists is on the oil's chemical composition and how much can be dissolved, accommodated and adsorbed into the water and sediment phase to assess the toxicity. As different components of the oil biodegrade at different speeds and have different impacts on the aquatic biota, it is important to know the composition of the petroleum hydrocarbons. It is, for example, almost impossible to obtain information on the content of polycyclic aromatic hydrocarbons (PAHs) in different types of oil. These compounds constitute a minor fraction of the mass of oil but are very toxic to the aquatic biota in small concentrations, and they adsorb easily to sediment particles because of their hydrophobicity.

\subsection{Experiences from oil spills at the Norwegian coast}

A considerable base of knowledge on the fate and effects of marine HFO spills is found in Boitsov et al. (2012) - "Experiences from oil spills at the Norwegian coast, a summary of environmental effects". Below excerpts from the report related to three oil spill accidents are provided.

\subsubsection{The Rocknes accident - January 2004}

The Rocknes accident led to a spill of more than 400 tons HFO (IFO 380 ) to the sea 45 kilometre of shoreline and 181 separate locations were contaminated by the oil spill. The concentrations of NPDs (naphthalene, phenanthrene, dibenzothiophene including their $\mathrm{C}_{1}-\mathrm{C}_{3}$ alkyl homologues) and $\mathrm{PAH}_{1} 6$ (polyaromatic hydrocarbons, reported as the sum of 16 representative compounds) content in mussels collected at the contaminated locations shortly after the accident, were relatively low. Readings after seven months revealed a further decline in the NPD and $\mathrm{PAH}_{1} 6$ content. Biomarker for damage to the lysosomal membrane and to DNA strands in mussels was also investigated. After seven months, there was a significant reduction in the biomarker responses. Salmon smolts from a contaminated farm were inspected. The first set of samples all had elevated levels of PAH metabolites in their bile, which is a sign of pollution. Seven months after the accident, the level of PAH metabolites had declined but was still above normal background levels. Although significant quantities of oil were found, the distribution of algae and fauna appeared to be unaffected. Between 2,000 and 3,000 seabirds were estimated to have died because of the oil pollution from the Rocknes accident. 


\subsubsection{The Server accident - January 2007}

The Server accident resulted in a spill of more than 380 tons HFO (IFO 180) to the sea. The oil spread quickly across a large area along the coast. Oil slicks were recorded at 230 locations, and 40 kilometre of shoreline were contaminated. Samples of water, fish, crabs and scallops were collected and analysed for their content of THC (total hydrocarbons) and PAH. The bile of the fish was also tested for PAH metabolites. One week after the incident, slightly elevated PAH values were recorded in the surface water close to the site of the accident. The report indicates that the bad weather led to extensive spreading and dilution of the oil. The low concentrations of oil suggested that the grounding of the Server did not have any long-term negative impacts on life in the water column.

PAH levels in fish and crabs caught close to the site of the accident were only slightly elevated one month after the spill. Low NPD and PAH levels were found in salmon from farms in the affected area. Increased levels of $\mathrm{CYP}_{1} A$ detoxifying enzymes were found in the livers of cod, pollack and ballan wrasse close to the wreck. Fish caught shortly (weeks) after the grounding of the Server showed little or no sign of toxic effects suffered from the oil spill.

The coastal zone was analysed using a grid system, in which all algae and fauna present in $0.5 \times 0.5 \mathrm{~m}$ grid squares were recorded. It was observed that channelled wrack (macroalgae) and certain animal species became less prevalent in the coastal zone. A survey of benthic fauna was also carried out. The number of individuals and species varied from station to station, but no negative impacts attributable to the oil spill were observed. At the stations with the highest levels of hydrocarbon content in their sediments, there were no signs of impact on the benthic fauna. A similar followup study was performed in summer 2009 at some of the stations used in 2007 and no evidence appeared that the oil spill from the Server had significantly affected the flora and fauna in the coastal zone. A quite high amount of channelled wrack was washed away during the cleanup operation, and in August 2009 the vegetation had still not recovered. However, as the species is widely distributed in the area, it is expected to fully reestablish itself within a few years.

The oil from the Server spread across a relatively large area. In total, 1,554 oiled birds belonging to 22 different species were reported. It was estimated that somewhere between 3,200 and 8,000 birds died because of the spill.

\subsubsection{The Full City accident - July 2009}

The Full City accident involved a spill of more than 290 tons HFO (IFO 180) to the sea. The oil spread quickly across a large area along the coast. Oil slicks were recorded at 200 locations, and 75 kilometre of the shoreline were contaminated. The environmental monitoring undertaken in connection with the Full City accident was more thorough than for previous similar incidents in Norway.

Samples of sea water, fish and crustaceans were taken a few days after the oil spill. Near the wreck, slightly elevated levels of contaminants were found in the livers and bile of ballan wrasse (NPDs, PAHs, PAH metabolites) and in seawater (NPDs and THCs), 
but not in fish muscle (fillet). Mussels from the coast that was most heavily contaminated exhibited significant levels of pollution (up to Class IV on the Klif scale in the case of benzo[a]pyrene). There was no evidence of oil contamination in fish, crab and seawater samples taken at some distance from the ship.

Four months after the accident, a significant reduction was observed in the concentration of oil components in cod liver and mussels. Thus, very low levels were recorded in all shrimp and fish samples.

Approximately eight months after the accident a further reduction was observed in the levels of oil components in mussels. The Norwegian Food Safety Authority withdrew its recommendation about not to consume mussels from a small area close to the site of the grounding. Presence of oil components in sediments collected in October-December 2009 from the affected area was studied and the main conclusion was that the sediments in the relevant area were not significantly contaminated by oil from the Full City, most likely due to strong currents and waves.

After the accident, impacts on phytoplankton, zooplankton and water chemistry were studied. The conclusion was that the oil spill had limited effect on the local phytoplankton, zooplankton and bacteria communities and that there were no measurable long-term impacts on their abundance or on the species composition. No changes were found in the water chemistry immediately after the accident or the following year.

Monitoring of fauna and flora in the littoral and sublittoral zone indicated that the oil-contaminated stations generally had fewer taxa and individuals than the stations with little or no oil, although more bladder wrack was found at the oil-contaminated stations. It is estimated that between 2,000-2,500 seabirds died because of the Full City accident.

\subsection{Summary}

Effects of HFO spill in the sea are closely related to the distribution and the chemical composition of the oil. In summary, the literature on effects of HFO spill in the sea indicates that:

1. Due to the low content of water soluble components in HFO as well as strong dilution in the sea, an HFO spill poses a small risk to the pelagic organisms. Environmental monitoring of HFO spills near the Norwegian coast indicates that the concentrations of oil components in the water column generally are low. Significant concentrations of oil components in the water are only found immediately under the slick, close to the wreck and just after the spill has happened. Thus, spill of HFO only seems to have limited and only local, minor effects on phytoplankton, zooplankton and bacteria communities in the water column. 
2. Due to the high likelihood that HFO remains on the sea surface, an HFO spill poses a high risk of smothering seabirds and polluting coastlines. Wind and sea current may spread HFO spills over large areas. Very often seabirds have suffered more from oil spills than other components of the ecosystem. The number of dead birds, in the event of an HFO spill, may serve as a good indicator of the total impact on the environment.

3. Shorelines protected against waves and containing soft sediment have a low selfcleaning potential and the degradation of oil is therefore slow, and they are thus particularly vulnerable to oil spills.

4. Oil beaching and smothering of macroalgae may affect the photosynthetic activity of macroalgae and consequently inhibit macroalgal growth. In addition, oil components may lead to, for example, poor zoospore attachment and delay the repair of damage to fucoid cover. 


\section{Possible oil spill response measures for Heavy Fuel Oil}

In the selection of oil spill response measures/strategy, it is important to have knowledge about the expected fate and behaviour of the oil as well as changes in properties with time, as described in the above chapters.

In general, the two most dominant processes determining the natural removal of oil from the water surface are evaporation and natural dispersion entrainment into the water column. Also emulsification will increase the oil volume significantly compared with the original amount of oil spilled. These processes depend on the ambient conditions prevailing in the particular situation such as wind and temperature. In the chapters above, examples have been provided of how the weathering processes change the properties of the HFO remaining on the sea surface. However, in general and compared with, for example crude oils, the evaporative loss of HFO is low (e.g. see Figure 5) and also the water uptake is generally lower compared with most crude oils.

Two primary methods are discussed in the reviewed literature as measures to be considered in relation to HFO response operations: oil spill dispersants and different types of mechanical recovery. Moreover, in situ burning is suggested as a possible countermeasure briefly mentioned by the end of the chapter.

\subsection{Mechanical recovery of HFO}

Mechanical recovery generally includes three different steps: 1) containment of the oil spill, 2) recovery of the contained oil and 3) pumping of the recovered oil to a storage tank.

Regarding containment of oil on the water surface, issues to consider are, for instance, possible leakage of the contained oil (boom failure below or above the boom). This is particularly relevant if currents are strong (Moldestad et al. 2007) and if the viscosity of the oil is too low. According to Moldestad and Resby (2001) a rule of thumb is that the viscosity of the oil must be above $1000 \mathrm{CP}$ to ensure that the oil is well fitted in the containment boom; otherwise, it will most likely escape underneath the boom. A too low viscosity is, however, not considered to be an issue regarding HFO, in particular in cold waters.

Many different types of commercially skimmers are available for recovery of oil. However, according to O'Brien (2002) the adhesive behaviour of viscous oil may destroy most standard skimmers, including oleophilic disc and drum skimmers, rope skimmers and weir skimmers. Some skimmers might be applied successfully, but great care must be exercised during the operation. SINTEF tested a weir skimmer whose efficiency declined when the oil became semi-solid (high wax content and pour point $10-15^{\circ} \mathrm{C}$ above sea water temperature) and if oil viscosity was above 10,000-20,000 mPas 
(Moldestad et al. 2007). In general, equipment that requires that the oil floats to the skimmer may be ineffective for oils with HFO properties (Moldestad et al. 2007).

However, skimmers have been and are still being specifically developed for very viscous oils. These include different types of toothed discs, inclined belts, paddle belts, helical drums, oleophilic drum or belt brushes (O'Brien 2002). These skimmers rely on processes such as actively dragging, pulling or lifting the oil.

Figure 10 illustrates the change in viscosity for emulsions during weathering at $5{ }^{\circ} \mathrm{C}$ for different oils (both HFO and crude oils) and provides indications (red lines) of the limits for avoiding boom leakage and of weir skimmer efficiency. The IFO380 and IFO650 tested were all within the viscosity range where the efficiency for weir skimmers as well as booms was limited.

Figure 10: Prediction of change in viscosity for different oil types, crude oils and HFOs

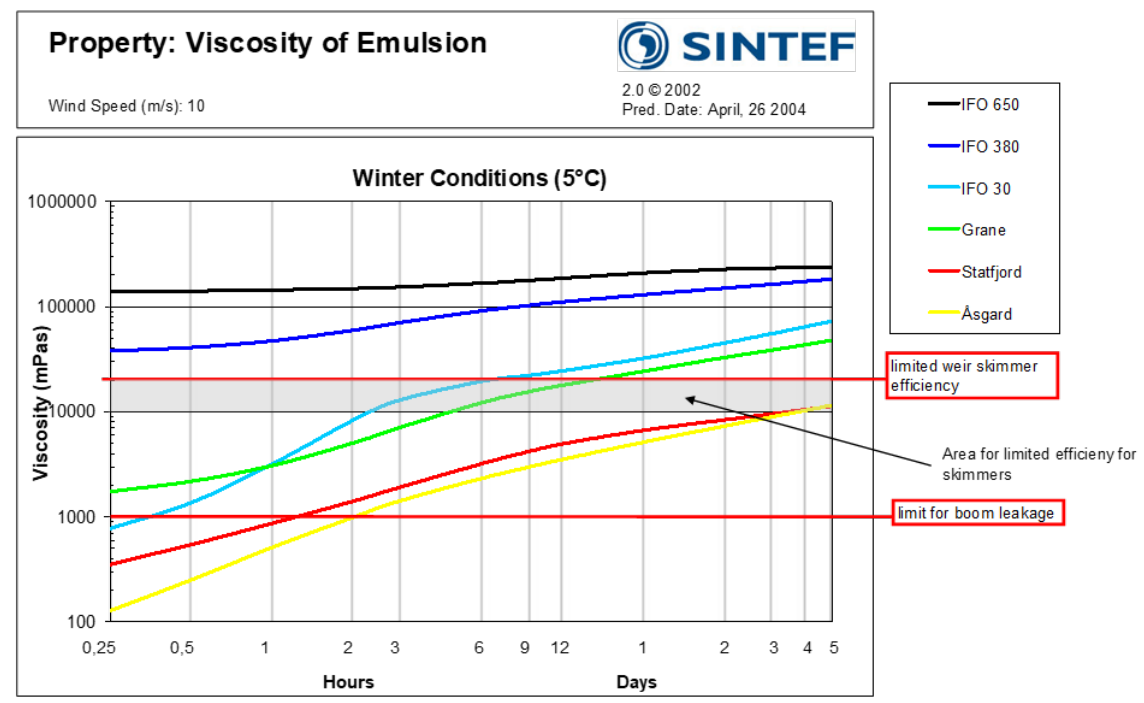

Source: Figure from Moldestad et al. (2007).

Pumping, from the skimmer to the storage tank, of HFOs is another issue to consider. During an oil spill response operation in 1989 in Norwegian waters, it was possible to pump an oil with a viscosity of 100,000 CP (shear rate $1 \mathrm{~s}-1$ ); the capacity was, however, low (Moldestad and Resby 2001). Thus, it seems that the most efficient way of handling very viscous oils might be simply lifting it by a mechanically grab or similar and directly moving the collected oil into the storage facility, thereby avoiding pumping the oil. This procedure has been used in connection with several oil spills. See O'Brien (2002) for further details.

Many of the issues related to high viscosity are similar to those related to semi-solid behaviour due to a high pour point. Being residual oil products, HFO types tend to have a relatively higher wax content and thus a higher pour point, which for many HFOs is higher than $30^{\circ} \mathrm{C}\left(\mathrm{O}^{\prime} \mathrm{Brien}\right.$ 2002). During the Baltic Carrier incident in the Baltic Sea, the spilled HFO became like chewing gum (O'Brien 2002).

Overall, the greater the viscosity, the slower/less successful and more labour demanding the operation will be as much of the standard and sophisticated recovery 
equipment will become coated and clogged and thus not work properly. Pumping may also be difficult. Under favourable conditions, it might be possible to collect the oil with low-tech mechanical grabs, but skimmers for high viscous oils are currently being developed. Among the skimmers developed for high viscous oils are the Desmi Terminator belt skimmer that pulls in the heavy oil and the Framo HiVisc skimmer that uses a hydraulically operated shovel to lift the oil. The Desmi skimmer was used during the Prestige oil spill. Different skimmers for high viscosity oil products have been tested by, for instance, the Norwegian Clean Seas for Operating Companies (Ohmsett 2013). A follow-up study after the Erika and Prestige incidents revealed a lack of knowledge about use of skimmer in relation to recovery of high viscous oils (Ly and Gåseidnes 2004).

\subsection{Use of chemical dispersant in relation to HFO}

Oil spill dispersant is an agent that enhances the natural dispersion processes, transferring the oil from the water surface into the water column. Dispersants consist of a complex mixture of surfactants, solvents and additives. A large variety of different types of commercially dispersants is available. The principle of dispersants is that 1 ) they are first sprayed onto the oil, 2) then the solvent transports the surfactant into the oil, 3) where the surfactant reduces the surface tension in the oil/water interface, thereby 4) allowing small oil droplets to break away from the slick, and by turbulent mixing the droplets disperse and rapidly dilute into the water column, leaving only a sheen on the water surface.

Accordingly, the major purpose of including dispersants in an oil spill response operation is to remove the oil from the water surface by enhancing the natural dispersion. This could increase the availability of microorganisms for biodegradation of the oil, thereby protecting sensitive coastlines or other sensitive areas/habitats.

For the chemical dispersants to be effective, the interaction between the dispersants and the oil, i.e. the specific compounds (waxes, resins, etc.) that the oil consists of, must be good (Moldestad et al. 2007). A high viscosity and pour point will counteract the mixing of the oil by waves into the water as well as inhibit the direct interaction between the oil and the chemicals, hence inhibiting the potential for efficient use of chemical dispersants (Moldestad et al. 2007). Consequently, the window of opportunity for using chemical dispersant will expectedly be reduced with longer weathering time.

Laboratory tests and field-scale experiments conducted in England in the $1990 \mathrm{~s}$ showed that HFOs were dispersible up to a certain viscosity (Lunel and Lewis 1999 and Lunel et al. 1998 in Sørheim et al. 2014). In field experiments, the viscosity of the oil was estimated to $20,000-40,000 \mathrm{cP}$ (at a shear rate of $10 \mathrm{~s}-1$ ), and it was found that the oil was only partly dispersible with low efficiency, in spite of successive applications of the dispersant by aircraft (Lunel et al. 1998 in Sørheim et al. 2014). Studies conducted in New Zealand (lab test at 5,10 and $15^{\circ} \mathrm{C}$ ) showed that some of the tested chemical dispersants were effective in dispersing different IFO380s (Stevens and Roberts 2003 in Sørheim et al. 2014). Laboratory studies have also been correlated with meso-scale experiments and field observations, and 
a good correlation within the ranking of different chemical dispersant products has been demonstrated (Clark et al. 2005, Belore et al. 2005, Trudel et al. 2005 and Colcomb et al. 2005 in Sørheim et al. 2014).

The dosages of chemical dispersant must be relatively high when applied to HFO spills, requiring minimum two application rounds ("successive application") (Sørheim et al. 2014). Two to three successive applications were found to be neseccary to, first, break the emulsion, by which the viscosity is reduced due to the decrease in the water content of the emulsion and, second, to disperse the oil into the water column. Therefore, in relation to dispersibility, the viscosity must be seen in connection with the ability to take up water. Heavier oil will typically take up less water and might be dispersible at higher viscosities compared with lighter oils (Sørheim et al. 2014).

The effect of several applications of dispersants and the impact on the viscosity and water content of the oil have been tested in meso-scale flume weathering experiments. Table 4 shows how the viscosity and water content change after up to three applications of chemical dispersant. After the first application, the water content was reduced in the 2.5 hour weathering experiment. In the 20 hour weathering experiments, the most significant effects regarding reduction of water content and viscosity occur after the second and third application, respectively. This highlights the importance of a short reponse time as the effectiveness of the dispersant declines, with the more weathered the oil. It can also be seen that the concentration of oil in the water increases with the number of appliciations, i.e. as the efficiency of the chemical dispersion processess increases.

Table 4: Meso-scale flume weathering experiments with IFO180 and use of the chemical dispersant Corexit 9500 after 2.5 hours and 20 hours

\begin{tabular}{|c|c|c|c|c|c|}
\hline \multirow{2}{*}{$\begin{array}{l}\text { Weathering } \\
\text { time }\end{array}$} & \multirow{2}{*}{$\begin{array}{l}\text { Chemical/Physical } \\
\text { analyses }\end{array}$} & \multicolumn{4}{|c|}{ Dispersant applied after } \\
\hline & & $\begin{array}{r}\text { Before } \\
\text { application }\end{array}$ & $\begin{array}{r}60 \text { min after } 15 t \\
\text { application }\end{array}$ & $\begin{array}{r}60 \text { min after } 2 \text { nd } \\
\text { application }\end{array}$ & $\begin{array}{r}60 \text { min after } 3 \text { rd } \\
\text { application }\end{array}$ \\
\hline \multirow[t]{3}{*}{$2.5 \mathrm{hr}$} & Viscosity (cP at $\left.10 \mathrm{~s}^{-1}\right)$ & 27,332 & 15,438 & 12,063 & - \\
\hline & Water content (vol\%) & 55 & 32 & 16 & - \\
\hline & Oil-in-water (ppm) & 0.4 & 101 & 457 & - \\
\hline \multirow[t]{3}{*}{$20 \mathrm{hr}$} & Viscosity (cP at $\left.10 \mathrm{~s}^{-1}\right)$ & 38,431 & n.a. & 25,915 & 1,6521 \\
\hline & Water content (vol\%) & 63 & 60 & 50 & 43 \\
\hline & Oil-in-water (ppm) & 1 & 28 & 178 & 589 \\
\hline
\end{tabular}

Source: Data input from Sørheim et al. (2014).

Figure 11 and 12 show successive application of dispersants and the resulting distribution of the oil. The figures are derived from a meso-scale experiment including IFO230 (Sørheim et al. (2014). The HFO was weathered for 24 hours at $15^{\circ} \mathrm{C}$ before the first amount of dispersant was applied, which resulted in around $50 \%$ dispersion. After the second application, less than $5 \%$ of the oil remained on the surface (Sørheim et al. 2014).

The pictures in Figure 13 show the development of an IFO180 in a meso-scale weathering experiment. At the end of the experiment, chemical dispersant was applied twice to the oil without a successful result (Moldestad and Resby 2001). 
Figure 11: Pictures from meso-scale weathering experiments at $15^{\circ} \mathrm{C}, \mathrm{IFO} 230$

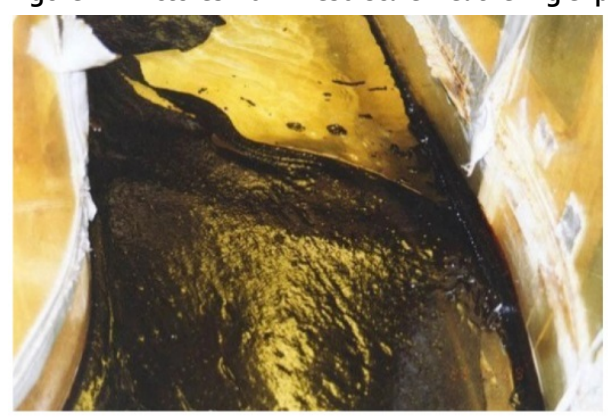

A) After 24 hours of weathering: viscosity $23000 \mathrm{CP}$ (53\% water)

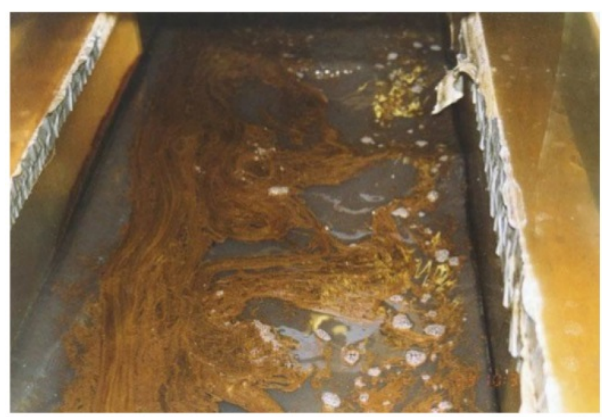

C) 30 min after the first application: approx.. $50 \%$ of the oil dispersed. Viscocity: 16570 CP (18\% water)

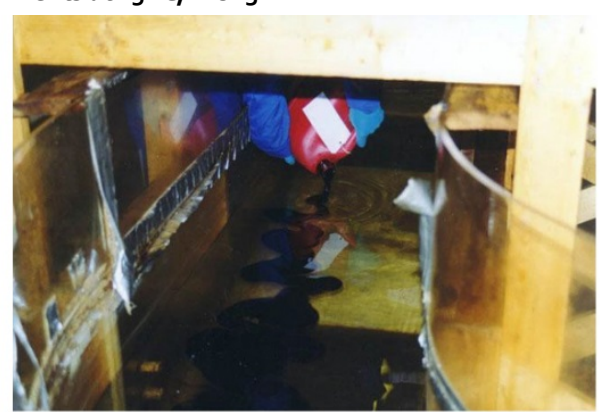

B) After 24 hours of weathering: application of dispersant

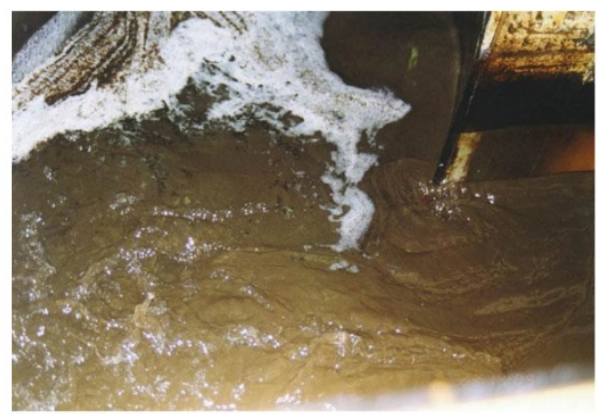

D) 30 min. after second application: $<5 \%$ oil film on the surface

Note: A) 24 hours of weathering, B) application of chemical dispersant, C) after first round of chemical dispersant application, D) after second application of chemical dispersant, $<5 \%$ oil left on the surface.

Source: Pictures from Sørheim et al. (2014).

Figure 12: Weathering of IFO230 in a meso-scale weathering flume

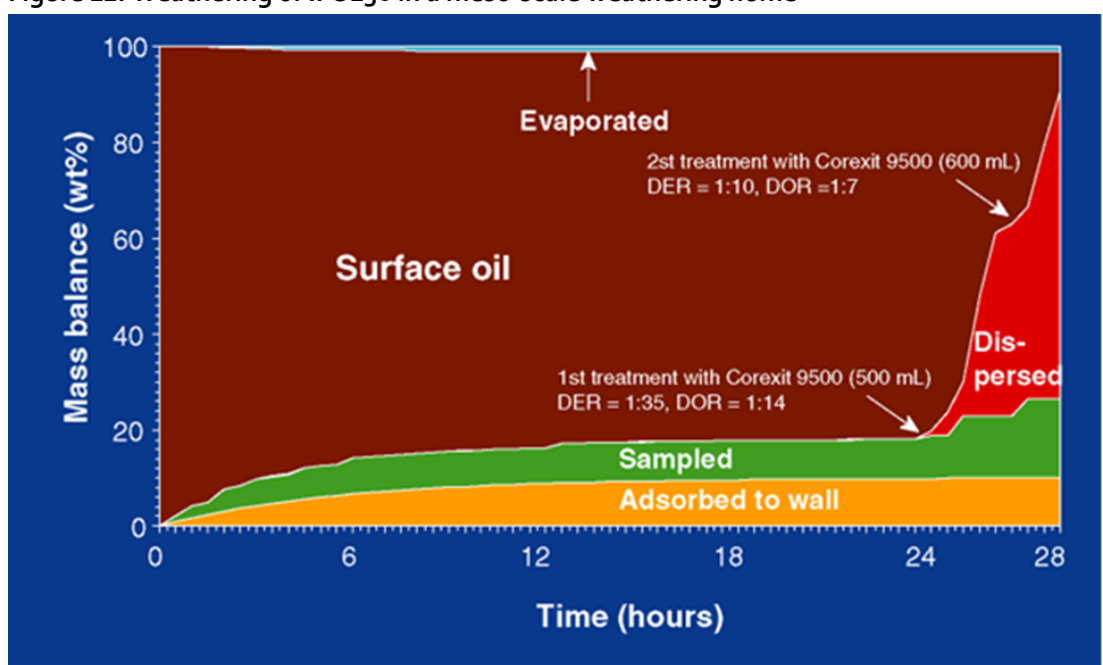

Note: After 24 hours, two rounds of chemical dispersants were applied to the oil slick. The pictures in Figure 11 are illustrations from the experiments. 
Figure 13: Pictures of the development of IFO180 after weathering for 72 hours followed by 2 times chemical dispersant application
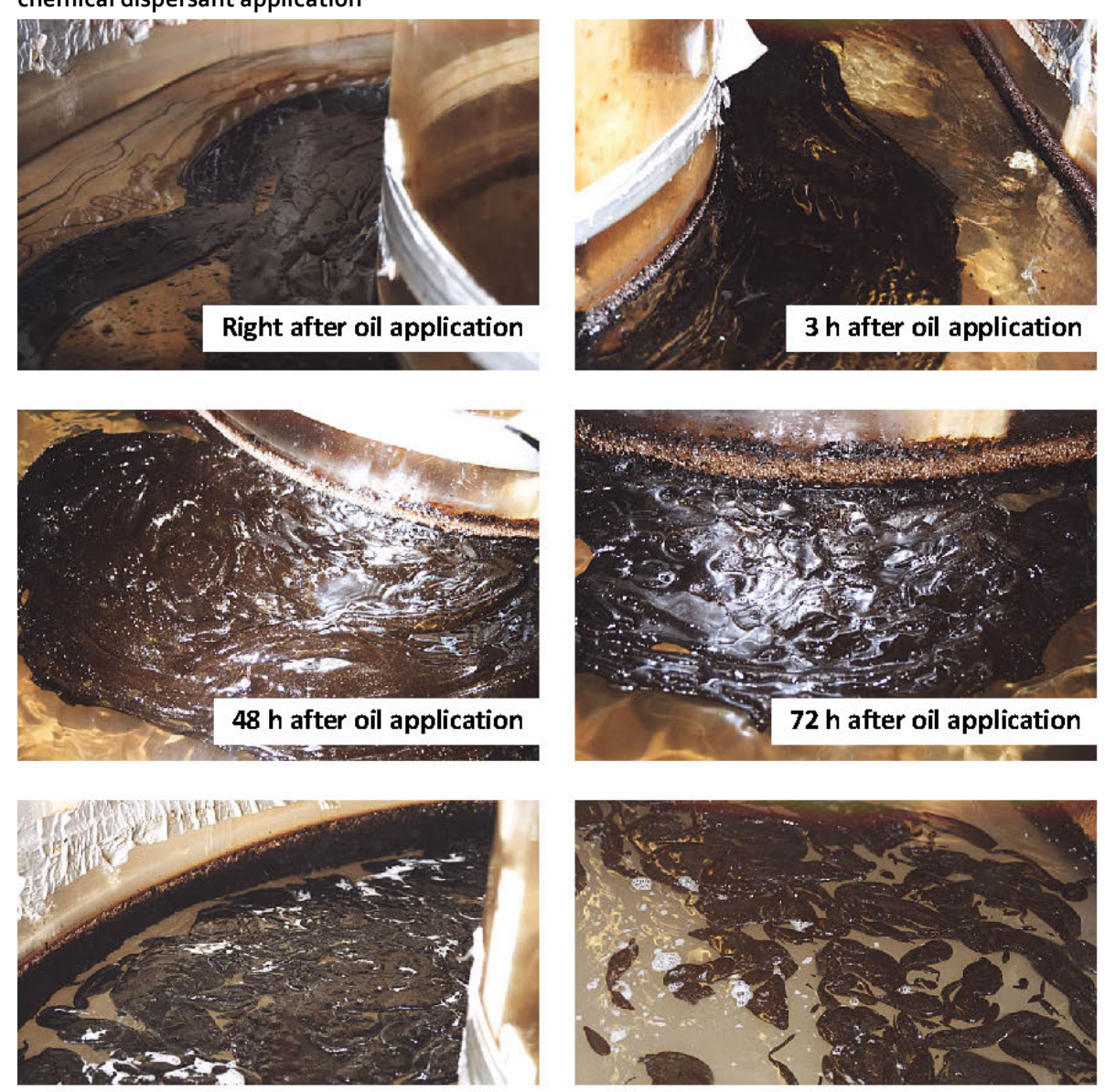

After 1x chemical dispersant application

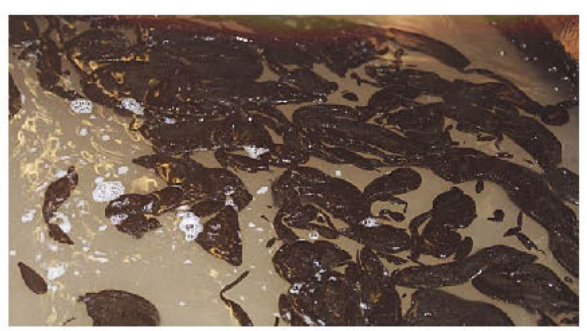

After $2 x$ chemical dispersant application
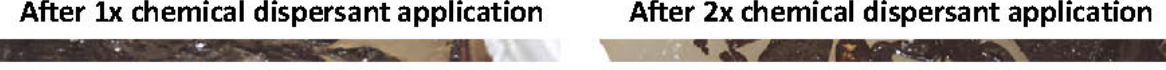

Source: From Moldestad and Resby (2001).

As shown in Chapter 4, there are large variations in HFO properties, influencing the dispersibility of the different oils.

Based on relatively few data, the chemical dispersability of different HFOs with time, at $5{ }^{\circ} \mathrm{C}$ and with a wind of $10 \mathrm{~m} / \mathrm{s}$, was predicted (see Figure 14) (Sørheim et al. 2014). The dark shaded area indicates poor dispersability. After 12 hours of weathering, all the HFOs tested are considered poorly dispersible. Note also that some of the bunker fuel oils are not dispersible at any point; IFO 380 is, for instance, considered not to be chemically dispersible at $5^{\circ} \mathrm{C}$. 
Figure 14: Weathering of five different HFOs at $5^{\circ} \mathrm{C}$ and $10 \mathrm{~m} / \mathrm{s}$

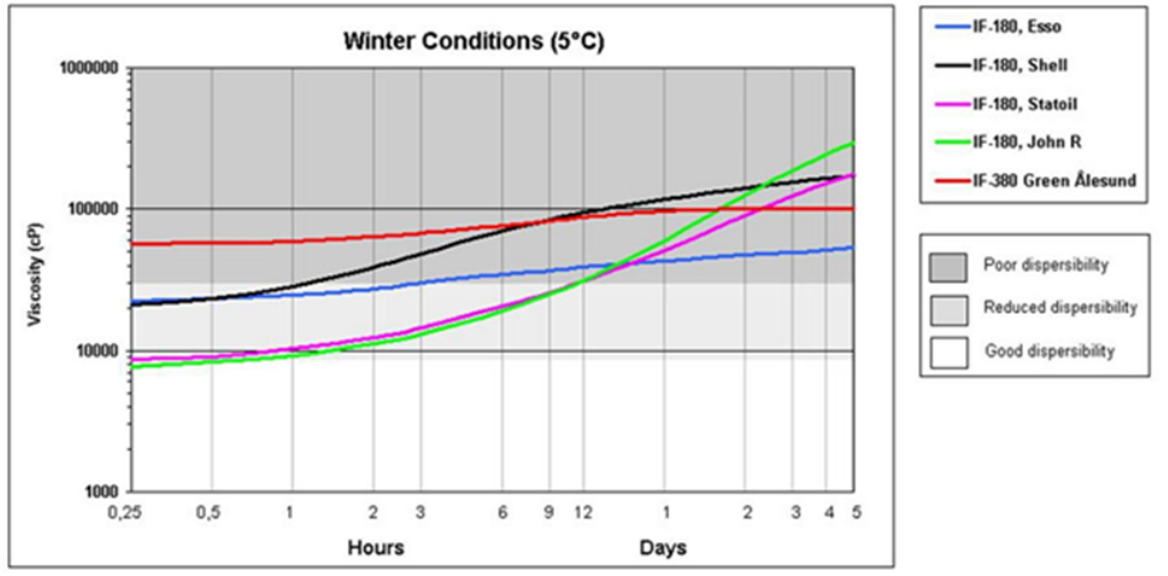

Source: From Sørheim et al. (2014).

Temperature influences dispersibility (Sørheim et al. 2014); thus, the lower the temperature, the more difficult it is to disperse the oil, in particular the heavier HFOs such as $\mathrm{IFO}_{3} 80$. Other tests have shown that some $\mathrm{IFO}_{3} 80$ s are dispersible at higher temperatures (Sørheim et al. 2014). For IFo180, several of the oils tested were dispersable also at low temperatures $\left(5^{\circ} \mathrm{C}\right)$, but less efficiently so than at $13^{\circ} \mathrm{C}$ (Sørheim et al. 2014).

Many different commercially available products exist, developed for different purposes/areas of use. Examples of the effectiveness of two different products for different HFOs are shown in Figure 15.

Figure 15: Effectiveness of two chemical dispersant products for different weathered HFOs. Small-scale laboratory testing of dispersibility at $5^{\circ} \mathrm{C}$

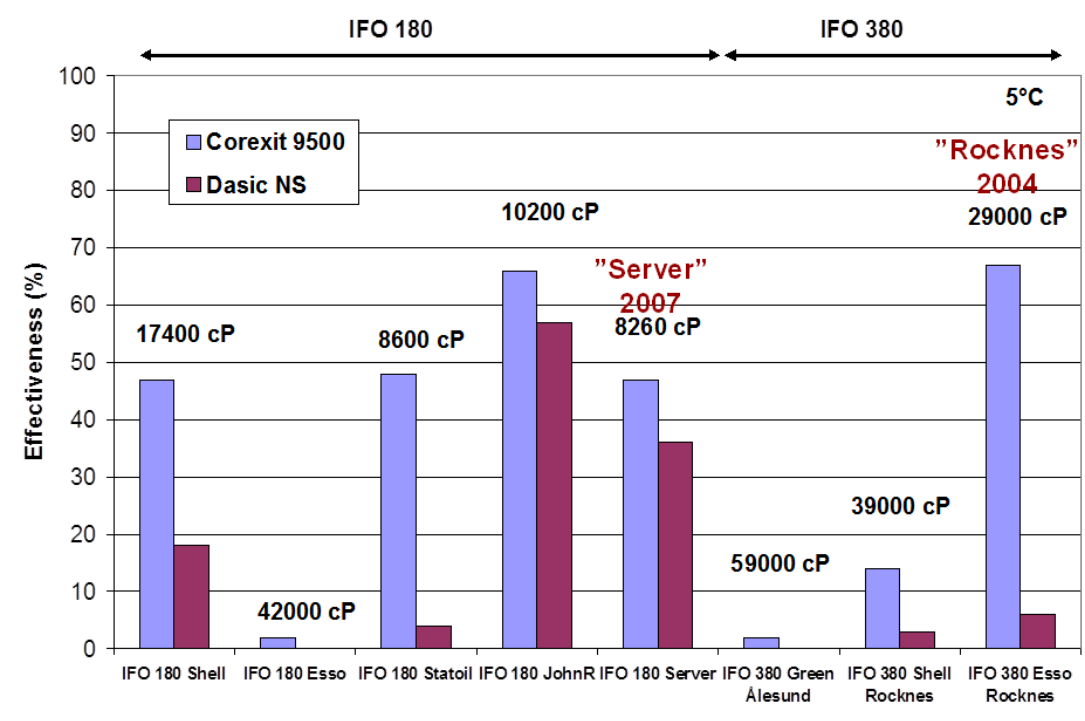

Source: Figure from Sørheim et al. (2014). 


\subsection{Use of in situ burning in relation to HFO}

In situ burning is an oil spill response technique where the oil is ignited and burned directly on the water surface. The oil slick must have a certain thickness to be ignitable. To achieve this, either fire resistant booms or in some situations also ice floes can be used to confine the oil. During ignition, an external source is used to heat the oil to its fire point at which the burn should be self-sustained. The success of igniting and burning thus decreases with increasing weathering of the oil, where processes such as evaporation of the light compounds and water-in-oil emulsification have a negative influence on the success.

Buist et al. (2013) completed a comprehensive review of in situ burning and found that:

- In general, in situ burning is not used for HFOs since these are difficult to ignite due to a small content of lighter compounds. This is also reflected in the rules of thumb that have been established regarding ignition and burn rate (see Table 5 and Table 6). It is evident that a relatively thick initial oil slick is needed to ignite HFO and when it burns, the removal rate is relatively low.

Table 5: Rule of thumb regarding minimum ignitable thickness

\begin{tabular}{ll} 
Note & Minimum ignitable thickness \\
\hline Fresh crude oil on water & About $1 \mathrm{~mm}$ \\
\hline Aged, unemulsified crude oil and diesel fuels & About 2 to $5 \mathrm{~mm}$ \\
Residual fuel oils, such as IFO 380 (aka Bunker "C" or No. 6 fuel oil) & About $10 \mathrm{~mm}$
\end{tabular}

Source From Buist et al. (2013).

Table 6: Rule of thumb regarding burn rate

Note Burn/removal rate

Gasoline $>10 \mathrm{~mm}$ thick

Distillate fuels (diesel and kerosene) $>10 \mathrm{~mm}$ thick

Crude oil $>10 \mathrm{~mm}$ (0.4 inches) thick $\quad 3.5 \mathrm{~mm} / \mathrm{min}$

Heavy residual fuels $>10 \mathrm{~mm}$ thick $2.0 \mathrm{~mm} / \mathrm{min}$

Source: From Buist et al. (2013).

Some examples of incidents involving HFO and in situ burning are shown in Table 7 below. Mixed results are found. The success of in situ burning during the vessel collision incident in Sweden might be due to the presence of pack ice resulting in reduced weathering and confinement of the oil, thereby ensuring ignitable slick thickness. 
Table 7: Examples of incidents involving the use of in-situ burning and HFO

\begin{tabular}{|c|c|c|c|c|}
\hline Date & Type/location & Description & Type & Results \\
\hline 1970 & $\begin{array}{l}\text { Accident in Chedabucto } \\
\text { Bay (Arrow) }\end{array}$ & $\begin{array}{l}\text { Some isolated slicks were burned using } \\
\text { Seabeads. Varsol also used as primer. } \\
\text { Oil on coastline was ignited and burned } \\
\text { with napalm and a flame thrower. }\end{array}$ & $\begin{array}{l}\text { Bunker } C \\
\text { approx. 16,000 } \\
\text { tons. }\end{array}$ & Mixed results. \\
\hline 1970 & $\begin{array}{l}\text { Vessel collision in Tralhavet } \\
\text { Bay, Sweden, March } \\
\text { (Othello and Katelysia) }\end{array}$ & $\begin{array}{l}\text { Spill was trapped in pack ice and a silica } \\
\text { wicking agent (Cab-O-Sil ST-2-o) was } \\
\text { used to burn. Conditions precluded } \\
\text { mechanical containment and recovery. }\end{array}$ & $\begin{array}{l}\text { Between } 52,000 \\
\text { and } 90,000 \text { tons } \\
\text { of Bunker C } \\
\text { spilled. }\end{array}$ & $\begin{array}{l}\text { Good results } \\
\text { reported. }\end{array}$ \\
\hline 1976 & $\begin{array}{l}\text { Tanker Argo Merchant went } \\
\text { aground off Nantucket }\end{array}$ & $\begin{array}{l}\text { Tullanox } 500 \text {, primed with JP- } 4 \text {, used as } \\
\text { igniter. }\end{array}$ & $\begin{array}{l}28,000 \text { tonnes of } \\
\text { No. } 6 \text { fuel. }\end{array}$ & $\begin{array}{l}\text { Not able to } \\
\text { burn slicks on } \\
\text { open water. }\end{array}$ \\
\hline 1999 & $\begin{array}{l}\text { New Carissa aground off } \\
\text { Oregon coast }\end{array}$ & On board ignition of spilled bunker fuel. & $\begin{array}{l}\text { Four different } \\
\text { bunkers. }\end{array}$ & $\begin{array}{l}\text { Oil burned in } \\
\text { hulk. }\end{array}$ \\
\hline
\end{tabular}

Small-scale laboratory burning experiments have been conducted with $\mathrm{IFO}_{30}$ and IFO180, including fresh fuels as well as emulsion, prepared by use of the rotating flask technique (modified method based on Mackay and Zargorski [1982]) (Fritt-Rasmussen 2010). The results show that the burning effectiveness decreases with increasing water content (Figure 16). By use of SINTEF OWM, the time window for implementing an in situ burning operation was identified - IFO30 was estimated to be ignitable for only 6 hours and IFO180 for even less (Fritt-Rasmussen 2010). The small-scale laboratory setup used has been verified against large-scale field experiments.

Field-scale in situ burning experiments were conducted in Greenland in summer 2017 with $\mathrm{FO}_{180}$ and a crude oil, however, results from these experiments are not yet available (EU H2O20 project GRACE Grant no. 67926620, Kim Gustavson, pers. comm.).

Figure 16: Burning effectiveness for $\mathrm{IFO}_{3} 0$ and $\mathrm{IFO}_{1} 80$ as a function of water content in the oil

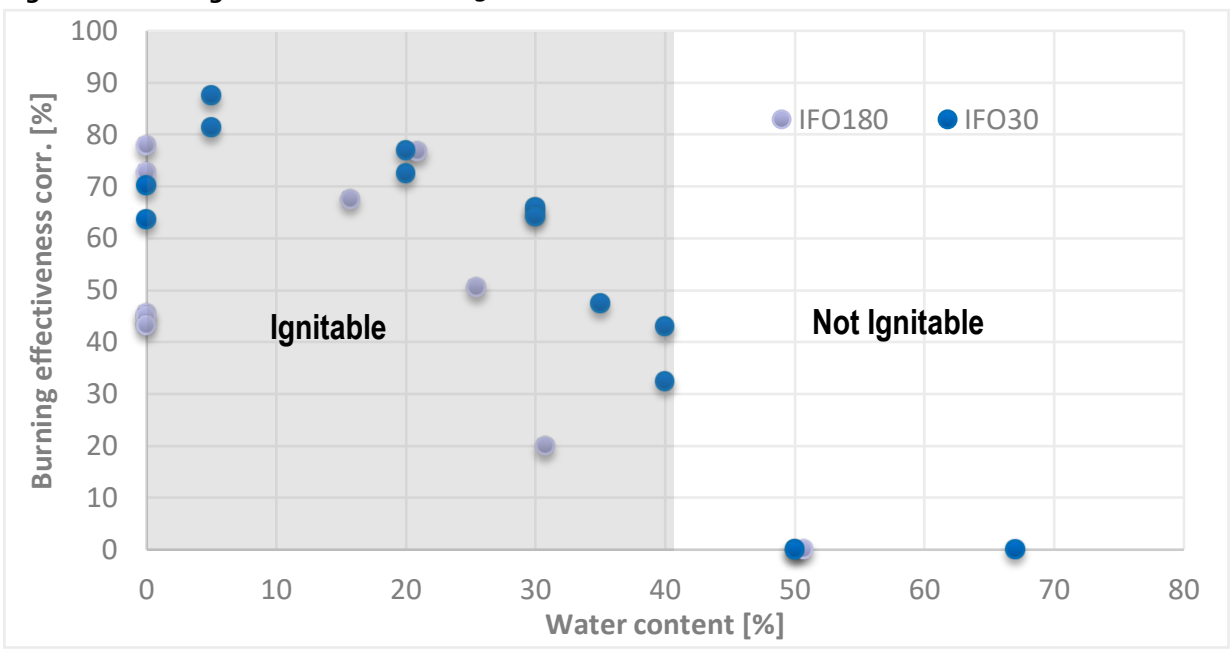

Note: The shaded area indicates where the fuel is considered ignitable.

Source: From Fritt-Rasmussen (2010) 


\subsection{Environmental benefit or consequences of response techniques}

In the following, the environmental benefit or consequences regarding the use of chemical dispersants and in situ burning to combat HFO oil spills is discussed. The environment will most likely benefit from mechanical removal of an oil spill as it implies that the oil is removed from the environment. The efficiency of the method may, however, be limited due to logistic and operational conditions, as discussed above, in which case chemical dispersants and/or in situ burning may be other options.

It may be more difficult to obtain sufficient dispersion rates and ignition/flame spread using dispersion and in situ burning for HFO than for lighter oil types (see above). This is because these operations must be initiated within a time frame where disperibility or ignitability is optimal, which is as soon as possible after the oil spill, in order to obtain the greatest overall benefit to the environment. As this time window may be tight, well-designed contingency plans and preparedness are essential. For this purpose, an open database on the responses of different oil types, their dispersibility and ignitability and time windows would add to the preparedness.

\subsubsection{Dispersants}

As already discussed above, some HFO types may not be chemically dispersable, due to factors such as high viscosity and high pour point. However, dispersibility and the time window for the operation are also functions of the oil type's ability to take up water. Therefore, as the ability of heavier oil types to take up water may be lower, they are likely to be more dispersible than lighter products. Although HFOs are dispersible, their dispersal involves use of a higher amount of dispersants as several application operations are needed (Sørheim et al. 2014).

A study of yellowtailed kingfish embryos exposed to dispersed HFO from the MV RENA accident in New Zealand in 2011 where the chemical dispersant Corexit 9500 was used showed that dispersion of HFO increased the PAH concentrations up to 27-fold. Also, the embryos exposed to Corexit 9500 exhibited higher mortality (Muncaster et al. 2016) than those treated with oil solutions. The authors suggest that this may be related to greater dissolution of PAHs in chemically dispersed oil due to the formation of micro-droplets and that the concentration of dispersant as well as the types of oil and dispersant used may all influence total PAH concentrations. Muncaster et al. (2016) also report that the concentration of dispersant used in their study likely contributed to the complete mortality of the embryos tested, although the ratio of dispersant to oil was in accord with the recommended guidelines, i.e. 1:20. An explanation may be rapid dilution of the dispersant when added to the sea, in contrast to the laboratory studies, although the dispersant concentrations in dilution simulations overlapped with $\mathrm{LC}_{50}$ for the early life stages of fish.

The findings of Muncaster et al. (2016) are supported by those of Koyama \& Kakuno (2004) that chemically dispersed HFO was more toxic to juvenile red sea bream than dispersant or oil alone. Adams et al. (2014) discovered that chemically dispersed HFO 
was more toxic to Atlantic herring embryos than the oil itself and that the increased toxicity was rather due to a higher degree of bioavailability of the dispersed oil than to changes in hydrocarbon toxicity.

Also, Martin et al. (2014) found that concentrations of chemically dispersed HFO were coincident with mortality of rainbow trout embryos.

To obtain sufficient dispersal efficiency, the ratio of dispersant to HFO may need to be increased to 1:10 (Lunel et al. No Date), which means that a 2-fold higher volume of dispersants and/or several applications may be required to obtain successful dispersion of HFO than for lighter oil types (as also shown in Chapter 8.2).

If the oil slick is missed during the several needed dispersant applications, a larger volume of chemicals will be added to the environment. This needs be considered in the NEBA performed for a potential dispersing operation. This also means that successful operations are essential.

If the HFO spill is successfully dispersed, it has to be considered that the resulting potentially higher concentration of dissolved PAHs may induce toxicity in pelagic organisms, particularly in the early stages (Muncaster et al. 2016).

\subsubsection{In situ burning}

The environmental impacts related to in situ burning can be divided into two categories: 1) the burn residue at the end of burning and 2) the smoke generated during burning.

In a review paper on burn residues from in situ burning (Fritt-Rasmussen et al. 2015), the chemical composition and environmental effects of burn residues are discussed. It is suggested that in situ burning of oil spills may reduce the amount and concentration of the most volatile, water-soluble, and generally more bioavailable, $\mathrm{PAHs}$ (three rings or less). The residues may thus be less toxic to aquatic organisms than the initial oil as the more volatile toxic compounds (e.g. benzene, naphatalene and benzopyrenes) are expected to be removed during the burning process. However, the review also indicated an increase in heavy PAHs (high ring number) from combustion, likely increasing the exposure of aquatic organisms to PAHs; heavier PAHs have a higher potential for bioaccumulation and, in addition, may include mutagens and carcinogens. Even a successful burning of HFO may hence leave a higher proportion of a more toxic and a less degradable fraction in the environment as the proportion of volatile and dissolvable components is smaller in HFO. On the other hand, such residue is also considered less bioavailable due to the low solubility in water.

The physical properties of the residue also vary depending on the initial oil and burning efficiency. It is expected that high density oil, such as HFO, will result in residues with an even higher density. Thus, there is a risk that the burn residue can sink. However, potential sinking and the physical properties of the residue are not yet well studied.

Also, the formation of smoke and soot is of environmental and health concern, in particular regarding inhalable particles and particle deposits (Figure 17). It is estimated that the soot formed during a burn equals $0.1-3 \%$ of the oil volume (ARRT 2008). 
However, the potentially relatively high content of sulphur in HFO could lead to higher soot production. Therefore, in this respect, the environment will also benefit from low fuel sulphur content requirements as these would diminish the potential negative side effects of in situ burning.

Figure 17: In situ burning experiment in Greenland 2017 (H2020 Project GRACE) with IFO180

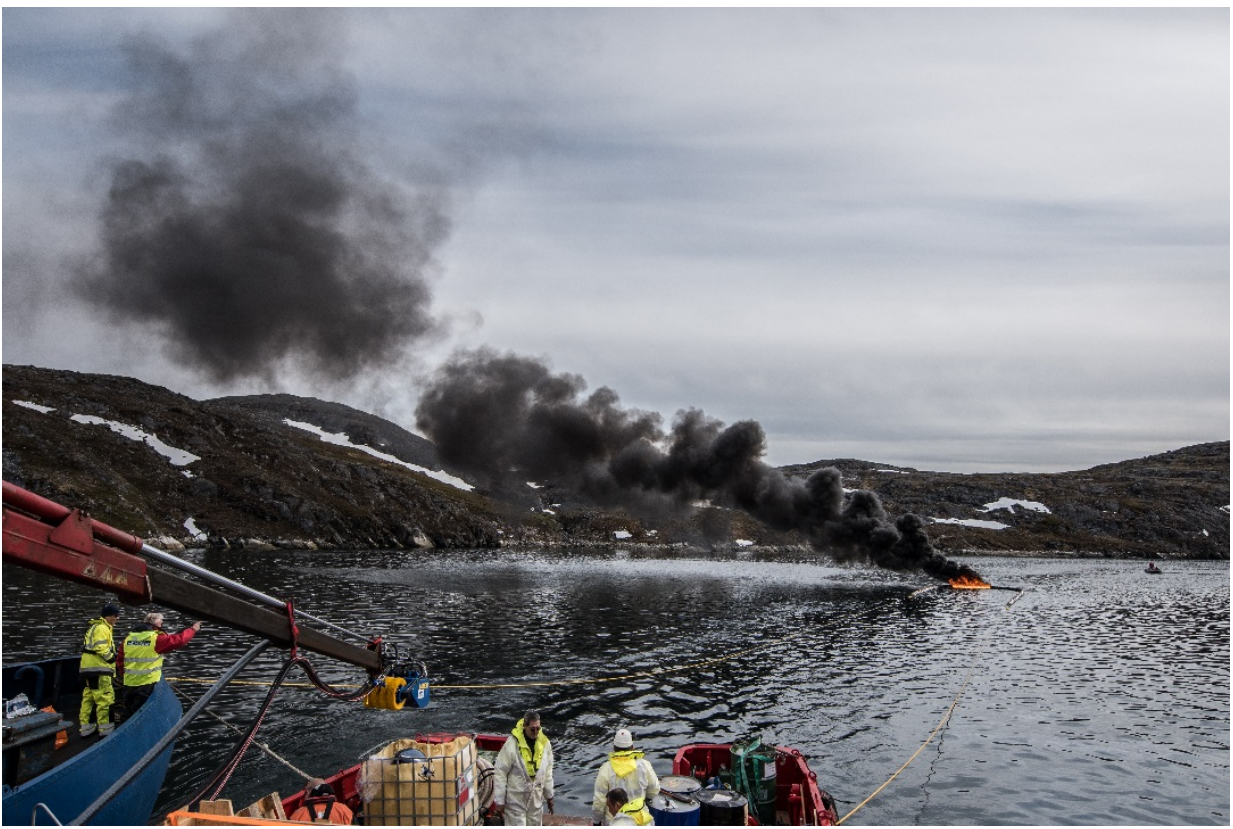

Source: EU H2020 Project Grace, Lars Demant-Poort 


\section{Knowledge gaps and research needs}

From the literature review, the following knowledge gaps and research needs were identified:

- More large-scale studies.

- More studies/experiments on HFO in ice.

- More focus/research and development of measures to recover the HFO from the water, including ice-infested water.

- Studies on ignitability of different HFOs/weathered products to determine the windows of opportunity for in situ burning.

- Studies on physical and bacterial degradation to support investigations into (bio) degradation in sea and beached oil.

- Studies on the biodegradation of dispersed HFO.

- Studies on environmental implications to support ongoing research into the smothering and ecotoxicological effects of HFO.

- Studies on the fate/distribution of different fractions of oil in water.

- Development of databases on dispersible and ignitable HFO types as well as on time windows of opportunity, including both tests and database development.

- More studies on the new generation of hybrid fuels. An increasing number of "new generation" low sulphur marine fuel oils (hybrid fuel oils) is currently being introduced in to the market and will replace the traditional HFOs. In the future, it will therefore be important to perform follow-up studies to characterise the new fuel oils to enable documentation of differences in fate and behaviour in the event of a spillage at sea, to document the potential/ feasibilities of the different response options as well as to enhance our knowledge about environmental impacts. 


\section{Conclusions and final remarks}

From the literature study, we extracted the below key findings.

First, it is important to be aware of the fact that HFO products with the same viscosity may exhibit large variations in properties due to differences in feed oil/distillate as well as refinery processes.

That said, there are some overall similarities. In general, HFO has very limited evaporation (typically less than $<10 \%$ ) and limited dispersion into the water column. However, the experiences from the Server incident showed that very rough weather conditions may increase the natural dispersion.

The water-in-oil emulsions vary from $20-65 \%$ in the reviewed reports. In addition, the stability of the emulsions varied with time and products. Tests using emulsion breakers to separate the water from the oil did not produce the expected effect.

Overall, as the weathering processes proceed, an increase in viscosity, density and pour point occurs.

All in all, HFO is likely more persistent on the water surface than lighter refined products, involving the risk that it may drift and impact other areas, for instance coastlines. This is in line with the overall findings from the four Norwegian oil spill incidents that the water surface, upper parts of the water column as well as the coastline are the most vulnerable parts of the environment.

With respect to oil spill response measures, some overall conclusions can be drawn:

The viscosity of HFO generally increases to above the theoretical limit for chemical dispersibility. However, successive application of chemical dispersant may occasionally produce successful dispersion, depending on, for example, the stability of the water-inoil emulsion.

HFOs are also difficult to handle using conventional containment and recovery measures, this is again due to the high viscosity inhibiting, for instance, skimming and pumping. To obtain successful dispersion, special equipment for high viscous products should be considered, including low tech methods.

The low content of volatile compounds in HFOs reduces the risk of explosion and fire during the first hours after release; however, this also reduces the possibility of a successful in situ burning operation. The in situ burning time-window is thus short, confined to a limited number of hours.

Natural biodegradation of HFO at low temperatures in seawater is limited by the low solubility and the low accommodated fraction of HFO in seawater. The use of dispersants can enhance the amount of oil in the seawater and thus also the biodegradation potential. Degradation rates are, however, low. Use of cold-adapted microbial addition (bioaugmentation) can enhance the biodegradation, but development of this technology is still in its initial phase. 
An increasing number of "new generation" low sulphur marine fuel oils (hybrid fuel oils) are currently being marketed and will replace the traditional HFO. This is due to the new regulations on the sulphur content of ship fuels (IMO MARPOL Convention.) that came into force in 2015 within the Sulphur Emission Control Areas (SECAs): Globally, ships will have to use fuels with a maximum sulphur content of not more than $0.1 \%$, and $0.5 \%$ from 2020 . Follow-up research to characterise the new fuel oils is therefore important to gain better documentation of differences in fate and behaviour in the event of a spill at sea, to document the potential/feasibilities of the different response options and to increase knowledge about environmental impacts. 


\section{Reference list}

ABS 2001. Notes on heavy fuel oil. 1984. American Bureau of Shipping.

Adams, J., Sweezey, M. \& Hodson, P. V. 2014. Oil and oil dispersant do not cause synergistic toxicity to fish embryos. Environmental Toxicology and Chemistry 33(1). DOI:

https://doi.org/10.1002/etc.2397.

Afenyo, M., Veitch, B. \& Khan, F. 2016. A state-of-the-art review of fate and transport of oil spills in open and ice-covered water. Ocean Engineering. 119, 233-248. DOI: https://doi.org/10.1016/j.oceaneng.2015.10.014.

ARRT (Alaska Regional Response Team) 2008. In situ burning guidelines for Alaska. Revision 1. iv $+66 \mathrm{pp}$.

Björklöf, K., Salminen, J., Sainio, P. \& Jørgensen, K. 2008. Degradation rates of aged petroleum hydrocarbons are likely to be mass transfer dependent in the field. Environmental Geochemistry and Health 30(2): 101-107. DOI: https://doi.org/10.1007/s10653-008-9148-y

Boitsov, S., Klungsøye, J. \& Dolva, H. 2012. Erfaringer etter oljeutslipp langs Kysten av Norge. Havforskningsinstituttet rapport Nr. 23-2012.

Brakstad, O. G. \& Bonaunet, K. 2006. Biodegradation of petroleum hydrocarbons in seawater at low temperatures $\left(0-5{ }^{\circ} \mathrm{C}\right)$ and bacterial communities associated with degradation. Biodegradation 17(1): 71-82. DOI: https://doi.org/10.1007/s10532-005-3342-8

Brakstad, O. G., Nonstad, I., Faksness, L.-G. \& Brandvik, P. J. 2008. Responses of microbial communities in Arctic sea ice after contamination by crude petroleum oil. Microbial Ecology 55(3): 540-552. DOI: https://doi.org/10.1007/s00248-007-9299-X

Brakstad, O. G., Nordtug, T. \& Throne-Holst, M. 2015. Biodegradation of dispersed Macondo oil in seawater at low temperature and different oil droplet sizes. Marine Pollution Bulletin 93(12): 144-152. DOI: https://doi.org/10.1016/j.marpolbul.2015.02.006

Brown, K. E., King, C. K., Kotzakoulakis, K., George, S. C. \& Harrison, P. L. 2016. Assessing fuel spill risks in polar waters: Temporal dynamics and behaviour of hydrocarbons from Antarctic diesel, marine gas oil and residual fuel oil. Marine Pollution Bulletin 110(1): 343-353. DOI: https://doi.org/10.1016/j.marpolbul.2016.06.042

Buist, I., Potter, S. G., Trudel, B. K., Shelnutt, S. R., Walker, A. H., Scholz, D. K., Brandvik, P. J., Fritt-Rasmussen, J., Allen, A. A. \& Smith, P. 2013. In itu Burning in Ice-Affected Waters: State of Knowledge Report. Report in prep. for the International Association of Oil \& Gas Producers, London, UK, pp. 1-317.

Cai, B., Ma, J., Yan, G., Dai, X., Li, M. \& Guo, S. 2016. Comparison of phytoremediation, bioaugmentation and natural attenuation for remediating saline soil contaminated by heavy crude oil. Biochemical Engineering Journal 112: 170-177. DOI:

https://doi.org/10.1016/j.bej.2016.04.018.

Coulon, F., Pelletier, E., Gourhant, L., Louis, R. S. \& Delille, D. 2004. Degradation of petroleum hydrocarbons in two sub-antarctic soils: Influence of an oleophilic fertilizer. Environmental Toxicology and Chemistry 23(8): 1893-1901. DOI: https://doi.org/10.1897/03-484

Crisafi, F., Giuliano, L., Yakimov, M. M., Azzaro, M. \& Denaro, R. 2016. Isolation and degradation potential of a cold-adapted oil/PAH-degrading marine bacterial consortium from Kongsfjorden (Arctic region). Rendiconti Lincei 27(1): 261-270. DOI:

https://doi.org/10.1007/s12210-016-0550-6

Daling, P.S., Brandvik, P.J., Mackay, D. \& Johansen, O., 1990a. Characterization of crude oils for environmental purposes. Pp.119-138 in Proceedings of the 13th Arctic and Marine Oil Spill

Program (AMOP) Technical Seminar. DOI: https://doi.org/10.1016/So269-8579(05)80027-9 
Daling, P. S., Mackay, D., Mackay, V. \& Brandvik, P.J. 199ob. Droplet size distribution in chemical dispersion of oil spills: Towards a mathematical model. Oil and Chemical Pollution. 7: 173-198. DOI: https://doi.org/10.1016/So269-8579(05)80026-7.

Delille, D. \& Coulon, F. 2008. Comparative mesocosm study of biostimulation efficiency in two different oil-amended sub-Antarctic soils. Microbial Ecology 56(2): 243-252. DOI:

https://doi.org/10.1007/s00248-007-9341-z.

Delille, D., Pelletier, E., Rodriguez-Blanco, A. \& Ghiglione, J.-F. 2009. Effects of nutrient and temperature on degradation of petroleum hydrocarbons in sub-Antarctic coastal seawater. Polar Biology 32(10): 1521-1528. DOI: https://doi.org/10.1007/s00300-009-0652-Z

Deppe, U., Richnow, H.-H., Michaelis, W. \& Antranikian, G. 2005. Degradation of crude oil by an arctic microbial consortium. Extremophiles 9(6): 461-470. https://doi.org/10.1007/s00792-0050463-2.

DNV 2011. Heavy fuel in the Arctic (Phase 1). Report no./DNV Reg. No.: 2011-0053/12RJ71W-4, Rev oo. $\mathrm{P}$

DNV 2012. DNV report shipping 2020. Shipping 2020. $68 \mathrm{pp}$.

DNV 2013. HFO in the Arctic - Phase 2. 2013-1542-16G8ZQC-5/1, DNV Doc. No./Report No.: 2013-1542-16G8ZQC-5/1

DNV GL 2015. Marine Environmental risk Assessment - Greenland. Report No.: 2014-0951, Rev. E. Prepared for Defense Command Denmark

Faksness, L.-G. 2008. Weathering of oil under Arctic conditions. Distribution and toxicity of water soluble oil components dissolving in seawater and migration through sea ice. A combined laboratory and field study. Dissertation for the degree philosophiae doctor (PhD) at the University of Bergen and The university Centre in Svalbard.

Fernández-Álvarez, P., Vila, J., Garrido-Fernández, J. M., Grifoll, M. \& Lema, J. M. 2006. Trials of bioremediation on a beach affected by the heavy oil spill of the Prestige. Journal of Hazardous Materials 137(3): 1523-1531. DOI: https://doi.org/10.1016/j.jhazmat.2006.04.035.

Fiocco, R. J., Daling, P. S., DeMarco, G. \& Lessard, R. R. 1999A. Advancing Laboratory/Field Dispersant Effectiveness Testing. Proceedings of the 1999 International Oil Spill Conference, API, Washington D.C.,

Fiocco, R., J., Daling, P. S., DeMarco, G., Lessard, R. R. \& Canevari, G. P. 1999B. Chemical Dispersibility Study of Heavy Bunker Fuel Oils. In: Proceedings of the 22nd Arctic and Marine Oil Spill Program (AMOP) Technical Seminar, June 2 to 4, 1999, Calgary Alberta, pp.173-186

Fritt-Rasmussen, J. 2010. In situ burning of Arctic marine oil spills: Ignitability of various oil types weathered at different ice conditions. A combined laboratory and field study. In Department of Civil Engineering. 2010, Technical University of Denmark.

Fritt-Rasmussen, J., Wegeberg, S. \& Gustavson, K. 2015. Review on Burn Residues from In Situ Burning of Oil Spills in Relation to Arctic Waters. Water Air Soil Pollution, 226: 329. DOI 10.1007/s11270-015-2593-1. DOI: https://doi.org/10.1007/s11270-015-2593-1.

Gallego, J. R., González-Rojas, E., Peláez, A. I., Sánchez, J., García-Martínez, M. J., Ortiz, J. E., Torres, T. \& Llamas, J. F. 2006. Natural attenuation and bioremediation of Prestige fuel oil along the Atlantic coast of Galicia (Spain). Organic Geochemistry 37(12): 1869-1884. DOI: https://doi.org/10.1016/j.orggeochem.2006.07.022.

Garneau, M.-Ė., Michel, C., Meisterhans, G., Fortin, N., King, T. L., Greer, C. W. \& Lee, K. 2016. Hydrocarbon biodegradation by Arctic sea-ice and sub-ice microbial communities during microcosm experiments, Northwest Passage (Nunavut, Canada). FEMS Microbiology Ecology 92(10): fiw130-fiw130. DOI: https://doi.org/10.1093/femsec/fiw130.

Garrett, R. M., Rothenburger, S. J. \& Prince, R. C. 2003. Biodegradation of fuel oil under laboratory and Arctic marine conditions. Spill Science \& Technology Bulletin 8(3): 297-302. https://doi.org/10.1016/S1353-2561(03)00037-9.

Genovese, M., Crisafi, F., Denaro, R., Cappello, S., Russo, D., Calogero, R., Santisi, S., Catalfamo, M., Modica, A., Smedile, F., Genovese, L., Golyshin, P. N., Giuliano, L. \& Yakimov, M. M. 2014. Effective bioremediation strategy for rapid in situ cleanup of anoxic marine 
sediments in mesocosm oil spill simulation. Frontiers in Microbiology 5: 162. DOI:

https://doi.org/10.3389/fmicb.2014.00162.

Gerdes, B., Brinkmeyer, R., Dieckmann, G. \& Helmke, E. 2005. Influence of crude oil on changes of bacterial communities in Arctic sea-ice. FEMS Microbiology Ecology 53(1): 129-139. DOI: https://doi.org/10.1016/j.femsec.2004.11.010.

Gerdes, B., D. Gerhard, C. Uhlig, Dahlmann, G., Widdel, F. \& Helmke, E. 2006. Efficiency of bioremediation and bioaugmentation in crude oil contaminated antarctic sea-ice. Doctoral thesis (Birte Gerdes, May 2006, Universität Bremen). p. 93-127.

Gerdes, B. 2006a. Impact of oil contamination and bioremediation treatments on efficiency of polar bacterial sea-ice-communities. Universität Bremen: Biologie/Chemie Vol. Doctor.

Gerdes, B., Dieckmann, G. \& Helmke, E. 2006b. Degradation of petroleum hydrocarbons by cold-adapted bacteria from Arctic and Antarctic sea-ice at low temperatures. Doctoral thesis (Birte, Gerdes, May 2006, Universität Bremen). p. 127-159.

Gerdes, B. Gerhard, D. \& Helmke, E. 2006c. Bioremediation field experiments with crude oil in sea-ice conducted in Van Mijenfjorden, Svalbard (2004). Doctoral thesis (Birte, Gerdes, May 2006, Universität Bremen). p. 159-175.

Germano de Almeida., D., Conceição da Silva, M. d.-G., Barbosa, R. d.-N., Silva, D. d.-S-P., Oliveira da Silva, R., Lima, G. M. d.-S., Buarque de Gusmão, N. \& Sousa, M. d.-F. V. d.-Q. 2017. Biodegradation of marine fuel MF-380 by microbial consortium isolated from seawater near the petrochemical Suape Port, Brazil, International Biodeterioration \& Biodegradation Volume 116: 73-82. DOI: https://doi.org/10.1016/j.ibiod.2016.09.028.

Gertler, C., Gerdts, G., Timmis, K. N., Yakimov, M. M. \& Golyshin, P. N. 2009. Populations of heavy fuel oil-degrading marine microbial community in presence of oil sorbent materials. Journal of Applied Microbiology 107(2): 590-605. DOI: https://doi.org/10.1111/j.13652672.2009.04245.x.

Hazen, T. C., Dubinsky, E. A., DeSantis, T. Z., Andersen, G. L., Piceno, Y. M., Singh, N., Jansson, J. K., Probst, A., Borglin, S. E., Fortney, J. L., Stringfellow, W. T., Bill, M., Conrad, M. E., Tom, L. M., Chavarria, K. L., Alusi, T. R., Lamendella, R., Joyner, D. C., Spier, C., Baelum, J., Auer, M., Zemla, M. L., Chakraborty, R., Sonnenthal, E. L., D'haeseleer, P., Holman, H.-Y. N., Osman, S., Lu, Z., Van Nostrand, J. D., Deng, Y., Zhou, J. \& Mason, O. U. 2010. Deep-sea oil plume enriches indigenous oil-degrading bacteria. Science 330(6001): 204. DOI: https://doi.org/10.1126/science.1195979.

Helmke, E., Gerdes, B., Juergens, J. \& Reuter, K. 2013. Bioremediation method for accelerated biological decomposition of petroleum hydrocarbons in sea ice-covered polar regions, and bacteria and enzyme mixtures as agents for carrying out said method. Google Patents.

Hellstrøm, K. C. 2017. Weathering properties and toxicity of marine fuel oils. Summary report. Report no. OC2017-124. SINTEF Ocean A/S

Hellstrøm, K. C., Daling, P. S., Brönner, U., Sørheim, K. R., Johnsen, M. \& Leirvik, F. 2017. Memo report. Collection of memos. Report no. OC2017-A123

Hozumi, T., Tsutsumi, H. \& Kono, M. 2000. Bioremediation on the Shore after an Oil Spill from the Nakhodka in the Sea of Japan. I. Chemistry and Characteristics of Heavy Oil Loaded on the Nakhodka and Biodegradation Tests by a Bioremediation Agent with Microbiological Cultures in the Laboratory. Marine Pollution Bulletin 40(4): 308-314. DOI:

https://doi.org/10.1016/Soo25-326X(99)00218-0.

Hua, J. 2006. Biodegradation of dispersed marine fuel oil in sediment under engineered pre-spill application strategy. Ocean Engineering 33(2): 152-167. DOI: https://doi.org/10.1016/j.oceaneng.2005.04.009.

IMO 2011. Antarctic fuel oil ban and North American ECA MARPOL amendments enter into force on 1 August 2011. http://www.imo.org/en/MediaCentre/PressBriefings/Pages/44MARPOL-amends.aspx\#.Vz8CVfPU_m8

IMO 2016. Prevention of air pollution from ships. http://www.imo.org/en/OurWork/Environment/PollutionPrevention/AirPollution/Pages/AirPollution.aspx). 
IMO 2017. Sulphur oxides (SOx) and Particulate Matter (PM) - Regulation 14. http://www.imo.org/en/OurWork/Environment/PollutionPrevention/AirPollution/Pages/Sulph ur-oxides-(SOx)-\%E2\%80\%93-Regulation-14.aspx

ITOPF 2016. http://www.itopf.com/in-action-de/case-studies/\#filter_top

Jiménez, N., Viñas, M., Bayona, J. M., Albaiges, J. \& Solanas, A. M. 2007. The Prestige oil spill: bacterial community dynamics during a field biostimulation assay. Applied Microbiology and Biotechnology 77(4): 935-945. DOI: https://doi.org/10.1007/s00253-007-1229-9.

Kadali, K. K., Simons, K. L., Sheppard, P. J. \& Ball, A. S. 2012. Mineralisation of weathered crude oil by a hydrocarbonoclastic consortia in marine mesocosms. Water, Air, \& Soil Pollution 223(7): 4283-4295. DOI: https://doi.org/10.1007/s11270-012-1191-8.

Kjølholt, J., Aakre, S., Jürgensen, C. \& Lauridsen, J. 2012. Assessment of possible impacts of scrubber water discharges on the marine environment. Danish Environmental Protection Agency Environmental Project No. 1431. pp. 92.

Koyama, J. \& Kakuno, A. 2004. Toxicity of heavy fuel oil, dispersant, and oil-dispersant mixtures to a marine fish, Pagrus major. Fisheries Science 70: 587-594. DOI:

https://doi.org/10.1111/j.1444-2906.2004.00845.x.

Kristensen, M., Johnsen, A. R. \& Christensen, J. H. 2015. Marine biodegradation of crude oil in temperate and Arctic water samples. Journal of Hazardous Materials 300: 75-83. DOI: https://doi.org/10.1016/j.jhazmat.2015.06.046.

Lewis, A. 2002. Composition, properties and classification of heavy fuel oils. Third R\&D Forum on High-density Oil Spill Response. Brest March 2002 pp.11-25.

Lin, X., Yang, B., Shen, J. \& Du, N. 2009. Biodegradation of Crude Oil by an Arctic Psychrotrophic Bacterium Pseudoalteromomas sp. P29. Current Microbiology 59(3): 341-345. DOI: https://doi.org/10.1007/s00284-009-9440-9.

Lunel, T., Crosbie, A., Davies, L., \& Swannell, R.P.J. No Date. The Potential for Dispersing Bunker C (IFO-380) Fuel Oils: Initial results. Report: AEA Technology, National Environmental Technology Centre, Culham, UK

Ly, J. M. \& Gåseidnes, K. 2004. Testing of eight oil skimmers in three high viscosity emulsions at the Norwegian Costal Administration Test Facility in Horten. Interspill 2004.

Mackay, D. \& Zargorski, W. 1982. Studies of water-in-oil emulsions. Environmental Canada, Ottawa, Ontario, report EE-34.

Margesin, R. \& Schinner, F. 1997. Bioremediation of diesel-oil-contaminated alpine soils at low temperatures. Applied Microbiology and Biotechnology 47(4): 462-468. DOI: https://doi.org/10.1007/s002530050957.

Martin, J.D., Adams, J., Hollebone, B., King, T., Brown, S. \& Hodson, P. V. 2014. Chronic toxicity of heavy fuel oils to fish embryos using multiple exposure scenarios. Environmental Toxicology and Chemistry 33(3): 677-687. DOI: https://doi.org/10.1002/etc.2486.

McFarlin, K. M., Prince, R. C., Perkins, R. \& Leigh, M. B. 2014. Biodegradation of dispersed oil in Arctic seawater at $-1^{\circ} \mathrm{C}$. PLoS ONE 9(1): e84297. DOI: https://doi.org/10.1371/journal.pone.0084297.

Medina-Bellver, J. I., Marín, P., Delgado, A., Rodríguez-Sánchez, A., Reyes, E., Ramos, J. L. \& Marqués, S. 2005. Evidence for in situ crude oil biodegradation after the Prestige oil spill. Environmental Microbiology 7(6): 773-779. DOI: https://doi.org/10.1111/j.14622920.2005.00742.x.

Moldestad, M. Ø. \& Resby, J. L. M. 2001. Forvitringsegenskapene til IF18o oljer fra Statol, Shell og Esso. SINTEF Report no. STF66 Aooog4 (in Norwegian).

Moldestad, M. Ø. \& Leirvik, F. 2003. The Prestige oil-Properties and Weathering at Sea. SINTEF report no. STF66 A03057.

Moldestad, M. $\varnothing . \&$ Daling P.S. 2006. Vurdering av forvitringsegenskapene til ulike Marine Gassoljer. Kriterier for fastsettelse av drivstoff kvalitet ut fra egenskaper ved et eventuelt utslipp. SINTEF report no. STF8oMK Ao6170 (in Norwegian). 
Moldestad, M. Ø., Lewis, A., Hauge, M. \& Røyset, J.-A. 2007. Safety at Sea. Oil Weathering. Demo A: Inventory, Classification and Risk Assessment of Oil Transport on the North Sea. SINTEF and the Norwegian Coastal Administration (NCA) report.

MST. 2014. Bekendtgørelse om svovlindholdet i faste og flydende brændstoffer. Miljømin., Miljøstyrelsen, j.nr. MST-5202-00112.

Muncaster, S. P., Jacobson, G., Taiarui, M., King, S. \& Bird, S. 2016. Effects of MV Rena heavy fuel oil and dispersed oil on yellowtail kingfish early life stages. New Zealand Journal of Marine and Freshwater Research, 50(1): 131-143. DOI:

https://doi.org/10.1080/00288330.2015.1078821.

National Research Council. 2014. Responding to oil spills in the U.S. Arctic marine environment. National Research Council. Pp. i-196

Ohmsett 2013. High Viscosity Offshore Skimmers Tested. Ohmsett Gazette. Sprin/Summer 2013.

https://www.ohmsett.com/research/Ohmsett\%20Gazette\%20Spring\%20Summer\%202013\% 2oFinal.pdf.

O'Brien, M. L. 2002. At-sea recovery of heavy oils - a reasonable response strategy? Third R\&D Forum on High-density Oil Spill Response. Brest March 2002 pp.11-25.

PAME. 2016. Possible hazards for engines and fuel systems using heavy fuel oil in cold climate. Rambøll and MARINTEK report on behalf of The Protection of the Arctic Marine Environment Working Group (PAME).

PAME II. 2016. Heavy fuel oil and other fuel releases from shippin in the Arctic and Near-Arctic. AMSA Recommendations I(B) and II(F) HFO Project Phase III.

$P B L$ 2012. Assessment of the environmental impacts and health benefits of a nitrogen emission control area in the North Sea. http://www.pbl.nl/en/publications/2012/assessment-of-theenvironmental-impacts-and-health-benefits-of-a-nitrogen-emission-control-area-in-thenorth-s).

Prince, R. C., McFarlin, K. M., Butler, J. D., Febbo, E. J., Wang, F. C. Y. \& Nedwed, T. J. 2013. The primary biodegradation of dispersed crude oil in the sea. Chemosphere 9o(2): 521-526. DOI: https://doi.org/10.1016/j.chemosphere.2012.08.020.

Prince, R. C., Nash, G. W. \& Hill, S. J. 2016. The biodegradation of crude oil in the deep ocean. Marine Pollution Bulletin 111(1-2): 354-357. DOI:

https://doi.org/10.1016/j.marpolbul.2016.06.087.

Reunamo, A., Riemann, L., Leskinen, P. \& Jørgensen, K. S. 2013. Dominant petroleum hydrocarbon-degrading bacteria in the Archipelago Sea in South-West Finland (Baltic Sea) belong to different taxonomic groups than hydrocarbon degraders in the oceans. Marine Pollution Bulletin 72(1): 174-180. https://doi.org/10.1016/j.marpolbul.2013.04.006.

Reunamo, A., Yli-Hemminki, P., Nuutinen, J., Lehtoranta, J. \& Jørgensen, K. S. 2017. Degradation of crude oil and PAHs in iron-manganese concretions and sediment from the Northern Baltic Sea. Geomicrobiology Journal 34: 385-399.

Salminen, J. M., Tuomi, P. M., Suortti, A.-M. \& Jørgensen, K. S. 2004. Potential for aerobic and anaerobic biodegradation of petroleum hydrocarbons in boreal subsurface. Biodegradation 15(1): 29-39. DOI: https://doi.org/10.1023/B:BIOD.0000009954.21526.e8.

Salminen, J. M., Tuomi, P. M. \& Jørgensen, K. S. 2008. Functional gene abundances (nahAc, alkB, $x y(E)$ in the assessment of the efficacy of bioremediation. Applied Biochemistry and Biotechnology 151: 638-652. DOI: https://doi.org/10.1007/s12010-008-8275-3.

Scheibye, K., Christensen, J. H. \& Johnsen, A. R. 2017. Biodegradation of crude oil in Arctic subsurface water from the Disko Bay (Greenland) is limited. Environmental Pollution 223: 738o. DOI: https://doi.org/10.1016/j.envpol.2016.12.032.

Sharma, P. \& Schiewer, S. 2016. Assessment of crude oil biodegradation in arctic seashore sediments: effects of temperature, salinity, and crude oil concentration. Environmental Science and Pollution Research 23(15): 14881-14888. DOI: https://doi.org/10.1007/s11356-0166601-9. 
Shigenaka, G. 2014. Twenty-Five Years After the Exxon Valdez Oil Spill: NOAA's Scientific Support, Monitoring, and Research. Seattle: NOAA Office of Response and Restoration. 78 pp.

Stepanyan OV. 2008. Effects of crude oil on major functional characteristics of macroalgae of the Barent Sea. Russion Journal of Marine Biology 34: 131-134. DOI:

https://doi.org/10.1134/S1063074008020077.

Stepanyan OV. \& Voskoboinikov GM. 2004. Effect of oil and oil products on morphofunctional parametres of marine macrophytes. Russioan Journal of Marine Biology 32: S32-S39. DOI: https://doi.org/10.1134/S1063074006070042.

Stephenson, R. 1997. Effects of oil and other surface-active organic pollutants on aquatic birds. Environ. Conserv. 24(2): 121-129. https://doi.org/10.1017/S0376892997000180.

Strøm, T. \& Guyomarch, J. 2008. Weathering properties and dispersability of one Russian Crude (REBCO) and one HFO Bunker fuel. SINTEF Report no. SINTEF A8569.

Sysselmannen 2017. Tungolje - forbudt I verneområder. https://www.sysselmannen.no/Naringsliv/Tungoljeforbud/

Sørheim, K.R., Daling, P.S., Pettersen, T-A \& Johansen, M. 2014. Dispergerbarhet av bunkersoljer. Projekt "Statlig dispergeringsberedskap" For Kystverket. A26179

Venosa, A. D. \& Holder, E. L. 2007. Biodegradability of dispersed crude oil at two different temperatures. Marine Pollution Bulletin 54(5): 545-553. DOI: https://doi.org/10.1016/j.marpolbul.2006.12.013.

Vila, J., Nieto, J. M., Mertens, J., Springael, D. \& Grifoll, M. 2010. Microbial community structure of a heavy fuel oil-degrading marine consortium: linking microbial dynamics with polycyclic aromatic hydrocarbon utilization. FEMS Microbiology Ecology 73(2): 349-362. DOI: https://doi.org/10.1111/j.1574-6941.2010.00902.x.

Wang, J., Wang, J., Zhang, Z., Li, Y., Zhang, B., Zhang, Z. \& Zhang, G. 2016. Cold-adapted bacteria for bioremediation of crude oil-contaminated soil. Journal of Chemical Technology \& Biotechnology 91(8): 2286-2297. https://doi.org/10.1002/jctb.4814.

Wegeberg, S., Gustavson, K., \& Fritt-Rasmussen, J. 2017. Oil smothering of Fucus distichus, effects and recover, Aarhus University, DCE - Danish Centre for Environment and Energy, scientic report, $18 \mathrm{pp}$.

Wegeberg, S., Johnsen, A., Aamand, J., Lassen, P., Gosewinckel, U., Fritt-Rasmussen, J., Rigét, F., Gustavson, K. \& Mosbech, A. 2018. Arctic marine potential of microbial oil degradation. Aarhus University, DCE - Danish Centre for Environment and Energy, 54 pp. Scientific Report from DCE - Danish Centre for Environment and Energy No. 271. http://dce2.au.dk/pub/SR271.pdf.

Yu, S., Li, S., Tang, Y. \& Wu, X. 2011. Succession of bacterial community along with the removal of heavy crude oil pollutants by multiple biostimulation treatments in the Yellow River Delta, China. Journal of Environmental Sciences 23(9): 1533-1543. DOI: https://doi.org/10.1016/S1001-0742(10)60585-2. 


\section{Sammenfatning}

Som følge af en øget afsmeltning af havis i Arktis vil nye sejlruter blive tilgængelige og skibsfartsaktiviteter på tværs af Arktis forventes at stige. Med en stigning i skibstrafikken øges sandsynligheden ligeledes for, at der kan forekomme olieudslip. For eksempel har DNV GL (PAME II [2016]) vurderet, at "en hændelse, der fører til et olieudslip, sandsynligvis vil ske hvert andet år i Beringhavet".

Tung bunkerolie (Heavy Fuel Oils (HFO)) fremstilles af en blanding af residual olie (restolie) og destillat, for eksempel marine dieselolier eller marine gasolier, som blandes til den ønskede viskositet. HFO består primært af restolie fra råolieraffinering. Idet HFO er relativt billigere sammenlignet med f.eks. lettere marine brændstoffer, anvendes det ofte som brændstof $\mathrm{i}$ skibsmotorer (PAME II 2016). HFO og residual olier bliver også transporteret som last, da sådanne højviskøse produkter ikke kan transporteres via rørledninger.

Både de fysiske egenskaber og den kemiske sammensætning af HFO varierer afhængigt af oprindelse og kvaliteten af restolien, destillatet og raffineringsprocesserne.

Viden om forskellige olietypers (herunder HFO) skæbne og opførsel er vigtig for at kunne vælge de mest effektive bekæmpelsesteknikker i en oliespildssituation samt i risikovurderingen af mulige olieudslip i kolde farvande. Også i forbindelse med en Net Environmental Benefit Analysis (NEBA, også kaldet SIMA-Spill Impact Mitigation Assessment) er denne viden afgørende for at sikre det bedste valg af metoder til oliespildsbekæmpelse og til beskyttelse af miljøet.

Dette projekt sigter mod at indsamle og styrke vidensgrundlaget omkring HFO i koldt havvand, dets skæbne og opførsel, herunder forvitring, biologisk nedbrydelighed, miljøkonsekvenser af spild med HFO, bekæmpelse af HFO spild, samt miljømæssig vurdering af bekæmpelsesmetoderne dispergering og afbrænding af olie på havoverfladen (in situ burning). Rapporten er baseret på eksisterende litteratur og laboratoriestudier med forvitring af HFO udført af SINTEF. Videnshuller og forskningsbehov for de behandlede emner er desuden identificeret og beskrevet.

Forvitring af HFO vil ændre oliens fysiske egenskaber. Generelt vil fordampningen af de forskellige typer af HFO være lav på grund af et fra begyndelsen lavt indhold af flygtige forbindelser samt tendensen til at danne tykke olielag, der hæmmer fordampningen. Den naturlige dispergering af olien i vandsøjlen har vist sig at være lav. Fordampning fører til yderligere øget viskositet, hældepunkt (pour point), densitet og flammepunkt, og olien vil derfor forblive på havoverfladen i længere tid. Vandoptagelse (emulgering) er også med til at stabilisere olien, hvilket alt i alt medfører at olien opholder sig længere på vandoverfladen. Imidlertid kan forvitring og/eller adsorption af uorganisk materiale i havet også medføre en højere densitet af olien end for vand, hvilket kan bevirke, at olien synker. 
En ny generation bunkerolier med lavt svovlindhold, også kaldet hybrid olier (hybrid fuel oils), er udviklet for at opfylde de nye krav og lovbestemmelser for udledning af potentielt skadelige stoffer, som for eksempel svovl, til luften. Et stigende antal hybrid olier produceres og introduceres for tiden på markedet, og erstatter derved de traditionelle HFO-typer. I lighed med de forskellige typer af HFO, har de nye hybrid olier også forskellige kemiske sammensætninger og egenskaber, og forventes derfor ligeledes at opføre sig forskelligt i tilfælde af et oliespild.

Med hensyn til muligheden for naturlig biologisk nedbrydning af HFO, er de overordnede konklusioner fra dette review, at nedbrydningen af olien reduceres ved lave temperaturer, og at nedbrydningshastigheden er begrænset af den mængde af olie, der kan opløses i vandfasen. Nedbrydningen af HFO i havvand er generelt langsommere sammenlignet med mellem og lette olieprodukter. Nedbrydning finder sted under anaerobe forhold $\mathrm{i}$ jord og sedimenter, dog halvt så hurtigt sammenlignet med aerobe forhold.

Miljøpåvirkningerne fra et oliespild på havet er tæt forbundet med oliens fysiske egenskaber og kemiske sammensætning samt de ændringer, der er opstår ved forvitring af olien. Generelt viser data fra undersøgelser af forvitring og skæbnen af $\mathrm{HFO}$, at de største miljømæssige problemer i forbindelse med HFO-spild ses i relation til vandoverfladen og på kysten. Den lave naturlige dispergering af HFO i vandsøjlen, forventes at medføre en relativt lav eksponering af organismerne i vandsøjlen for HFO i tilfælde af et spild. Derimod er der en høj risiko for, at havfugle og andre marine dyr, der opholder sig på havoverfalden og langs kysterne, bliver smurt ind i olie. På vind- og bølgebeskyttede kyster, og i bløde sedimenter, udvaskes HFO kun langsomt, mens eksponerede klippekyster har et højere selvrensende potentiale. Olieforurening i sedimenter kan således være langvarig og have langsigtede negative effekter på bentiske organismer. Foreløbige undersøgelser viser, at også tilsøling af makroalger i tidevandszonen med HFO kan påvirke algernes fotosyntese negativt. De miljømæssige konsekvenser af de forskellige HFO-typer forventes derfor mest relateret til arter og organismer på havoverfladen og langs kysten. Dette er også set i forbindelse med miljøovervågning af fire norske udslip af $\mathrm{HFO}$.

Muligheden for at bekæmpe spild af HFO er især begrænset af oliens høje viskositet, høje hældepunkt samt evnen til at danne stabile vand-i-olie-emulsioner. Endvidere kan tidsvinduet for kemisk dispergering af olien og in situ burning være relativt kort. Det kan være muligt at gennemføre en succesfuld dispergeringsoperation, men afhængig af stabiliteten og viskositeten af vand-i-olie-emulsionen er gentagne tilførsler af dispergeringsmiddel muligvis nødvendig. Mekanisk oprensningsudstyr bør enten være lavteknologisk og/eller systemer udviklet specifikt til olieprodukter med høj viskositet.

En gennemgang af de miljømæssige konsekvenser af de forskellige bekæmpelsesmetoder viste, at kemisk dispergeret HFO generelt er mere giftig i miljøet end olien alene, idet den dispergerede olie er mere biotilgængelig. For at opnå en tilstrækkelig spredningseffekt kan det desuden være nødvendigt at øge forholdet mellem dispergeringsmidlet og HFO (Dispersant Oil Ratio, DOR), DOR 1:10, dvs. op til 2 gange mere dispergeringsmiddel i forhold til ved lettere olietyper, som typisk har en 
DOR på 1:25. Det kan også være nødvendigt at gentage dispergeringen flere gange for at opnå, at olien dispergeres tilstrækkeligt. Dette betyder, at hvis det mislykkes at ramme oliespildet med dispergeringsmidlet eller at forvitringsgraden af HFO betyder at olien ikke længere er dispergerbar, kan en uhensigtsmæssig stor, og potentiel toksisk mængde dispergeringsmiddel ende $\mathrm{i}$ miljøet. Dette bør inddrages $\mathrm{i}$ den Net Environmental Benefit Analysis (NEBA) som udføres i forbindelse med en potentiel dispergeringsoperation. Såfremt dispergeringen af HFO er vellykket, bør den højere eksponering af organismerne i vandsøjlen, f.eks. zooplankton og fisk, ligeledes inddrages i en NEBA.

I forhold til afbrænding af olien på havoverfladen (in situ burning), viser dette review, at det er vigtigt, i forbindelse med udarbejdelse af en NEBA, at være opmærksom på den øgede koncentration af tunge PAH'er (polycyklic aromatic hydrocarbons) i afbrændingsresterne. Dette kan medføre en længerevarende påvirkning af miljøet efter et oliespild, idet PAH'er har et større potentiale for at ophobe sig i fødekæden (bioakkumulering) og kan indeholde mutagener og kræftfremkaldende stoffer. På den anden side vil den totale mængde af olie reduceres og således mindske mængden af vandopløselige og biotilgængelige forbindelser. Derudover bør dannelsen af røg og sod vurderes i forhold til de sundhedsmæssige og miljømæssige påvirkninger, især med hensyn til luftbårne partikler, der kan inhaleres og afsættes i miljøet. Så selvom bekæmpelse af et oliespild kan reducere mængden af olie i miljøet betydeligt, efterlader afbrændt HFO også en højere andel af en mere giftig og mindre nedbrydelig oliefraktion i miljøet, idet andelen af flygtige og opløselige komponenter er mindre i HFO.

Reviewet viser, at der er et behov for studier i stor skala og forsøg med HFO i havis, for at øge vidensgrundlaget for hvordan HFO bedst bekæmpes. Herunder at identificere det operative tidsvindue for kemisk dispergering og afbrænding, samt at indsamle information om hvordan HFO nedbrydes (både forvitret og kemisk dispergeret HFO) og opfører sig (skæbne) og påvirker miljøet (forskellige oliefraktioner og økotoksicitet, herunder tilsøling). For at kunne sammenligne de nye hybridolier, der forventes på markedet de kommende år, er det vigtigt at disse karakteriseres. Formålet er at få bedre dokumentation for variationer i skæbne og opførsel af disse nye produkter i tilfælde af spild på havet samt at dokumentere potentialet af de forskellige bekæmpelsesmetoder og de miljømæssige konsekvenser. 


\section{Appendix 1 - Literature search strategy for the review}

\section{Literature search strategy for the HFO fate and behaviour review}

In our literature search reviewing available literature about HFO and its fate and behaviour in cold marine environments, the following search words/search strategy were used (Table 8 and Table 9).

Table 8: Relevant search words

\begin{tabular}{ll} 
Topic & Search words \\
\hline Related to oil type & $\begin{array}{l}\text { HFO*, Heavy Fuel Oil*, IFO*, Intermediate Fuel Oil*, Fuel Oil*, Bunker } \\
\text { Oil*, Residual Fuel Oil*, Residual Fuel*, Residual Oil*, Marine Fuel Oil*, } \\
\text { Marine Fuel*, Marine Oil* }\end{array}$ \\
\hline Related to fate/behaviour/weathering & $\begin{array}{l}\text { Fate, Behavio*, Weatheri*, Spill*, Accident*, Tank*, Release*, Propert*, } \\
\text { Change* }\end{array}$ \\
\hline Related to the cold marine environment & Cold*, Arctic*, Marine* \\
\hline
\end{tabular}

Note: * = wildcard symbol; "..." search for exact term/phrase.

Table 9: Systematic search strategy, including search terms (italic) and search operators (AND/OR)

Intermediate Fuel Oil* AND Fate AND spill AND weathering

Intermediate Fuel Oil* AND Fate AND spill AND weathering AND marine

Intermediate Fuel Oil* AND Fate AND spill AND weathering AND marine AND cold

Residual Fuel Oil* AND Fate AND spill AND weathering AND marine AND cold

Residual Fuel Oil* AND Fate AND spill AND weathering AND marine AND arctic

HFO AND Fate AND spill AND weathering AND marine AND arctic

IFO* AND Fate AND spill AND weathering AND marine AND arctic

HFO* AND Fate AND spill AND weathering AND marine AND arctic AND oil

HFO* AND Fate AND spill AND weathering AND marine AND arctic AND oil AND behavi* \\ Number of hits}

Note: * = wildcard symbol; "..." search for exact term/phrase.

The literature search identified very few relevant literature sources, and particularly few on Arctic/cold relations. Even though many words were included in the search strategies to narrow the search, a relatively high number of hits were found, of which most had no relevance.

Moreover, we had access to the reports prepared by SINTEF, which are mostly based on laboratory small-scale and meso-scale weathering experiments and predictions of the oil weathering and behaviour in the SINTEF Oil Weathering Model (OWM). 


\section{Literature search strategy for the oil biodegradation review}

Searches were conducted in the Sciencedirect, Springerlink and Pubmed databases using the search words given in Table 10. Furthermore, a few articles were added based on knowledge of the subject.

Articles that combined both heavy fuel oils and biodegradation at cold temperatures were preferred, but also articles on biodegradation of medium or lighter fractions at cold temperatures or biodegradation of heavier fuel oils at higher temperatures were included. In addition, when choosing the articles, those including both or either of the conditions, heavy fuel oils and/or biodegradation at cold temperatures, were preferred.

Table 10: Search words used in the article search

\begin{tabular}{ll} 
Topic & Search words \\
\hline Related to oil type & $\begin{array}{l}\text { Heavy fuel oil, marine fuel oil, oil, residual oil "Heavy fuel oil", "marine fuel } \\
\text { oil", "residual oil" }\end{array}$ \\
\hline Related to biodegradation & Biodegradation \\
\hline Related to the cold marine environment & Arctic, cold, low temperature, marine \\
\hline
\end{tabular}




\section{Appendix 2 - Oil spills with HFO in cold/Arctic environment}

From PAME II (2016) a list of shipping incidents involving HFO between 1970 and 2014 are given (See Table 11). The geographical locations for the listed incidents are in Arctic and non-Arctic waters defined for the purpose of the study (PAME II 2016) above latitude $55^{\circ} \mathrm{N}$. The table has been updated with other cold water-related incidents reported at either the ITOPF homepage (ITOPF 2016) or at the Norwegian coastguard homepage (http://kystverket.no) or from SINTEF homepage.

According to ITOPF, amongst the 20 largest tanker oil spills since 1967, only Exxon Valdez is considered as sub-Arctic. Exxon Valdez included spill of crude oil, Alaska North Slope, and thus did not involve HFO.

On 28 January 1989, Bahia Paraíso, an Argentine resupply vessel grounded and sank less than 2 kilometre from Palmer Station on the Antarctic Peninsula. 600,000 L of diesel were released into the marine environment (Penhale et al. 1997).

\begin{tabular}{|c|c|c|c|}
\hline Vessel flag & Spill date & Spill amount \& type & Location of incident \\
\hline Golden Trader & $9 / 10 / 2011$ & $\begin{array}{l}\text { Approx. } 205 \text { tons of IFO spilled after bulk carrier Golden } \\
\text { Trader collided with the fishing vessel Vidar. } \\
60 \mathrm{~m}^{3} \text { recovered by Danish vessels. } \\
\text { A large amount of oil later was later washed ashore on } \\
\text { the Swedish west coast and recovered by Swedish } \\
\text { authorities. }\end{array}$ & Skagerrak (Denmark and Sweden). \\
\hline $\begin{array}{l}\text { Godafoss } \\
\text { Malaysia }\end{array}$ & $2 / 17 / 2011$ & Approx. 200 tons of HFO spilled. & Hvaler Islands off SE coast of Norway. \\
\hline Full City Panama & $7 / 31 / 2009$ & Approx. 300 tons of HFO and diesel fuel spilled. & Langesund, southern Norway. \\
\hline $\begin{array}{l}\text { Propontis } \\
\text { Greece }\end{array}$ & $02 / 2007$ & $\begin{array}{l}\text { No oil spilled (used to show how an ecological disaster } \\
\text { was avoided) }\end{array}$ & West of Suursaari, Russia. \\
\hline Server & $01 / 2007$ & Approx. 520 tons bunker oil spilled (out of 676 tons). & Fedje, Norway. \\
\hline $\begin{array}{l}\text { Selendang Ayu, } \\
\text { Malaysia }\end{array}$ & $12 / 8 / 2004$ & $\begin{array}{l}\text { About } 336,000 \text { gallons: } 321,052 \text { of IFO } 380 \text { \& } 14,680 \text { of } \\
\text { marine diesel/other oils. }\end{array}$ & $\begin{array}{l}\text { Bering Sea (near Unalaska Island, } \\
\text { Alaska; just outside near-Arctic at } 53 \\
{ }^{\circ} \mathrm{N} \text { ). }\end{array}$ \\
\hline Rocknes & 2004 & $\begin{array}{l}466 \text { tons of IFO } 380 \text { and } 78 \text { tons of marine diesel as } \\
\text { well lubricating oil. }\end{array}$ & Bergen, Norway. \\
\hline $\begin{array}{l}\text { Fu Shan Hai, } \\
\text { China }\end{array}$ & $5 / 31 / 2003$ & $\begin{array}{l}1,680 \text { tons of HFO, } 110 \text { tons of diesel oil, } 35 \text { tons of } \\
\text { lubricating oil. Remaining oil was recovered by the } \\
\text { wreck in } 2013 \text {. }\end{array}$ & $\begin{array}{l}\text { Bulk carrier sank after colliding with } \\
\text { Polish container ship Gdynia } \\
\text { northwest of the Danish Island of } \\
\text { Bornholm in the Baltic Sea. }\end{array}$ \\
\hline $\begin{array}{l}\text { Baltic Carrier } \\
\text { Marshall Islands }\end{array}$ & $3 / 29 / 2001$ & 2,400 tons of HFO. & $\begin{array}{l}\text { Baltic Sea (East of Falster Island, } \\
\text { Denmark). }\end{array}$ \\
\hline
\end{tabular}




\begin{tabular}{|c|c|c|c|}
\hline Vessel flag & Spill date & Spill amount \& type & Location of incident \\
\hline Green Ålesund & 2000 & 100 tons of HFO. & Haugesund, Norway. \\
\hline Janra Germany & $12 / 23 / 2000$ & 40 tons of HFO. & Sea of Aland, Finland. \\
\hline $\begin{array}{l}\text { Nefterudovoz-7 } \\
\text { Russia }\end{array}$ & 10/09/1999 & 75 tons of fuel oil. & St. Petersburg, Russia. \\
\hline $\begin{array}{l}\text { Volgo-Don } 5088 \\
\text { Russia }\end{array}$ & 06/1999 & 12 tons of chemicals. & St. Petersburg, Russia. \\
\hline Omsky Russia & 05/1999 & 10 tons of oil. & St. Petersburg, Russia. \\
\hline Nunki Malta & 1998 & 100 tons of oil. & Kalundborg Fjord, Denmark. \\
\hline Kotlin & 1998 & 37.5 tons of oil. & Kronshtadt, Russia. \\
\hline Tosna & 1998 & 25 tons of oil. & St. Petersburg, Russia. \\
\hline Dar-20 & 1998 & 17 tons of oil. & Jaroslawiec, Poland. \\
\hline Leros Strength & 1997 & 150 tons of HFO & Karmøy. Norway. \\
\hline Halsingland & 1997 & 70 tons of oil. & Kalajoki, Finland. \\
\hline $\begin{array}{l}\text { M/V Kuroshima } \\
\text { Panama }\end{array}$ & $11 / 26 / 1997$ & 38,976 gallons of bunker oil. & $\begin{array}{l}\text { Summer Bay near Unalaska Island, } \\
\text { Alaska (just outside near-Arctic at } 54 \\
\left.{ }^{\circ} \mathrm{N}\right) 80 \text {. }\end{array}$ \\
\hline $\begin{array}{l}\text { Hual Trooper } \\
\text { Germany }\end{array}$ & 1995 & 180 tons of HFO. & The Sound, Sweden. \\
\hline Oden Sweden & 1995 & 12.5 tons of oil. & Stockholm, Sweden. \\
\hline Oihonna Finland & 1995 & 81.25 tons of HFO. & Kotka, Finland. \\
\hline Kreva & $3 / 19 / 1995$ & 27.5 tons of diesel fuel and HFO. & Husum, Sweden. \\
\hline Kihnu Estonia & $1 / 16 / 1993$ & 1,000 tons $\mathrm{HFO}$ and 460 tons diesel fuel. & Tallinn, Estonia \\
\hline $\begin{array}{l}\text { Frank Michael } \\
\text { Germany }\end{array}$ & $10 / 10 / 1993$ & 1,703 tons of chemical fertilizer. & Faro, Sweden. \\
\hline Arisan & 1992 & 150 tons HFO. & Runde, Norway. \\
\hline $\begin{array}{l}\text { Konstantin } \mathrm{T} \text {. } \\
\text { Greece }\end{array}$ & 1992 & 12.5 tons of oil. & Husum, Sweden. \\
\hline Valyr & 1992 & 15 tons of oil. & Vysotsk, Russia. \\
\hline Pamisos Greece & 1992 & 12.5 tons of HFO. & Aland, Finland. \\
\hline Sonata & 1991 & 200 tons of HFO. & Ålesund, Norway. \\
\hline Antares & 1991 & 15 tons of oil. & Rauma, Finland. \\
\hline Sterno & 1990 & 15 tons of oil. & Glan, Sweden. \\
\hline Azalea & 1990 & 330 tons of HFO. & Haugesund, Norway. \\
\hline $\begin{array}{l}\text { Volgoneft } 26383 \\
\text { USSR }\end{array}$ & $5 / 14 / 1990$ & 800 tons of HFO. & Baltic Sea, Sweden. \\
\hline Finn-Baltic & $12 / 27 / 1990$ & 37.5 tons of oil. & Hanko, Finland. \\
\hline $\begin{array}{l}\text { Milos Reefer } \\
\text { Greece }\end{array}$ & $11 / 15 / 1989$ & 237,343 gallons of IFO \& diesel fuel. & $\begin{array}{l}\text { Bering Sea (near NE corner of St. } \\
\text { Matthew Island, Alaska). }\end{array}$ \\
\hline $\begin{array}{l}\text { Mercantile } \\
\text { Marica }\end{array}$ & 1989 & 340 tons of HFO, 55 tons of diesel. & Sognesjøn, Norway. \\
\hline $\begin{array}{l}\text { T/N Oriental Crane } \\
\text { Sierra Leone }\end{array}$ & $12 / 12 / 1988$ & 7,600 gallons of bunker oil. & Nikiski, Alaska. \\
\hline $\begin{array}{l}\text { Antonio Gramsci } \\
\text { USSR }\end{array}$ & $2 / 6 / 1987$ & $\begin{array}{l}600-700 \text { tons of crude oil released after tanker } \\
\text { grounded near Borga on the south coast of Finland. }\end{array}$ & Borga, Finland. \\
\hline Sotka Finland & $09 / 09 / 1985$ & 370 tons of HFO. & Market, Finland. \\
\hline Eira Finland & $08 / 31 / 1984$ & 300 tons of HFO. & Qvarken, Finland. \\
\hline $\begin{array}{l}\text { Globe Asimi } \\
\text { Gibraltar }\end{array}$ & $11 / 22 / 1981$ & $\begin{array}{l}\text { Several thousand tons of HFO spilled into the Port of } \\
\text { Klaipeda, USSR. The HFO later drifted out to the sea. }\end{array}$ & Port of Klaipeda, USSR. \\
\hline Deifovos & 1981 & 1000 tons of HFO, 150 tons of diesel. & Norway, Helgelandskysten. \\
\hline $\begin{array}{l}\text { M/V Kurdistan } \\
\text { Britain }\end{array}$ & $3 / 15 / 1979$ & 6,000 tons ( 43,900 barrels) of Bunker $C$. & Cabot Strait, Newfoundland, Canada. \\
\hline $\begin{array}{l}\text { Antonio Gramsci } \\
\text { USSR }\end{array}$ & 2/27/1979 & 5,500 tons of crude oil spilled after tanker grounded. & Ventspils, USSR in the Baltic Sea. \\
\hline $\begin{array}{l}\text { T/V Tsesis Russia } \\
\text { (Soviet Union) }\end{array}$ & 10/26/1977 & 1,100 tons of \# 5 Fuel Oil and Bunker C. & Sodertalje, Sweden. \\
\hline Arrow Liberia & $2 / 4 / 1970$ & 10,000 tons of Bunker $C$. & $\begin{array}{l}\text { Chedabucto Bay, Nova Scotia, } \\
\text { Canada. }\end{array}$ \\
\hline Esso Nordica & $09 / 25 / 1970$ & 600 tons of light fuel oil. & Pellinki, Finland. \\
\hline Pensa & $12 / 06 / 1970$ & 500 tons of light fuel oil. & Hailuoto, Finland. \\
\hline Palva Russia & $05 / 01 / 1969$ & 200 tons of crude oil. & Uto, Finland. \\
\hline
\end{tabular}




\section{Appendix 3-Biodegradation studies overview}

Table 12: Biodegradation studies related to water compartment

\begin{tabular}{|c|c|c|c|c|c|c|c|c|c|c|}
\hline \multicolumn{11}{|c|}{ Biodegradation studies conducted in seawater } \\
\hline Study name & Oil type & $\begin{array}{r}\text { Initial } \\
\text { concentratio } \\
n(\mu g / L)\end{array}$ & Experiment type & Compartment & Sample type and location & Study time & Temperature & Oil detection method & $\begin{array}{l}\text { Molecular biology } \\
\text { methods }\end{array}$ & $\begin{array}{l}\text { Biodegradation rate } \\
\text { or percentage }\end{array}$ \\
\hline $\begin{array}{l}\text { Darne Germano de } \\
\text { Almeida et al. } 2017\end{array}$ & Heavy fuel oil (MF-380) & 30,000 & $\begin{array}{l}\text { Bioreactor using pure } \\
\text { microbe cultures }\end{array}$ & Water & $\begin{array}{l}\text { Microbes: Extracted from } \\
\text { seawater sample taken from } \\
\text { Petrochemical Suape Port (Brazil) }\end{array}$ & $24 d$ & $25-35^{\circ} \mathrm{C}$ & GC-MS & $16 S$ DNA sequencing & $\begin{array}{l}\text { Overall } \mathrm{HC} \\
\text { degradation: } 87.12- \\
93.53 \%\end{array}$ \\
\hline Hozumi et al. 2000 & $\begin{array}{l}\text { Heavy fuel oil } \\
\text { (Nakhodka heavy oil, } \\
\text { Bunker C heavy oil, } \\
\text { diesel) }\end{array}$ & 1,000 & $\begin{array}{l}\text { Microcosm, } \\
\text { bioaugmentation } \\
\text { (TerraZyme) }\end{array}$ & Water & $\begin{array}{l}\text { Oil samples taken from } \\
\text { Nakhodka, Japan Sea (Japan) }\end{array}$ & $21 \mathrm{~d}$ & $25^{\circ} \mathrm{C}$ & GC, TLC-FID & No & $\begin{array}{l}\text { Bunker C heavy oil: ca. } \\
30 \% \text {, Nakhodka: } 30 \% \text {. }\end{array}$ \\
\hline Brown et al. 2016 & $\begin{array}{l}\text { Heavy fuel oil (SAB, } \\
M G O, \text { IFO180) }\end{array}$ & 700 & Microcosm & Water/WAF & Filtered seawater & $7 \mathrm{~d}$ & o and $5^{\circ} \mathrm{C}$ & GC-FID & No & $\begin{array}{l}\text { IFO } 180: 71 \%\left(0^{\circ} \mathrm{C}\right) \\
65^{2} \%\left(5^{\circ} \mathrm{C}\right)\end{array}$ \\
\hline Gertler et al. 2009 & Heavy fuel oil (IFO 180) & 4,900 & $\begin{array}{l}\text { Microcosm, } \\
\text { biostimulation, } \\
\text { bioaugmentation }\end{array}$ & Water & Seawater: Helgoland (Germany) & 6 weeks & $17^{\circ} \mathrm{C}$ & GC-MS & $\begin{array}{l}\text { DGGE, RISA, } \\
\text { sequencing }\end{array}$ & $\begin{array}{l}\text { Augmented-seawater: } \\
95 \% \text { (aliphatics), ca. } \\
80 \% \text { (branched), ca. } \\
90 \% \text { (polyaromatic). }\end{array}$ \\
\hline Vila et al. 2010 & $\begin{array}{l}\text { Heavy fuel oil (fuel oil } \\
n^{\circ} 6 \text {, collected from } \\
\text { Prestige) }\end{array}$ & $5,000,000$ & Microcosm & Water & $\begin{array}{l}\text { Oil sample: Costa de la Muerte, } \\
\text { La Coruna (Spain) }\end{array}$ & 6od & $25^{\circ} \mathrm{C}$ & GC-FID, GC-MS & $\begin{array}{l}\text { DGGE, 16S rRNA, } \\
\text { sequencing }\end{array}$ & $>40 \%(\mathrm{TPH})$ \\
\hline $\begin{array}{l}\text { Venosa and Holder } \\
2007\end{array}$ & $\begin{array}{l}\text { Heavy hydrocarbon } \\
\text { fractions (heavy crude } \\
\text { oil Prudhoe Bay) }\end{array}$ & 800 & Microcosm & Water & $\begin{array}{l}\text { Culture: Disk Island, Alaska, } \\
\text { (USA) }\end{array}$ & $\begin{array}{l}46 \mathrm{~d}\left(\text { at } 5^{\circ} \mathrm{C}\right) \\
28 \mathrm{~d}\left(\text { at } 20^{\circ} \mathrm{C}\right)\end{array}$ & $5^{\circ} \mathrm{C}$ and $20^{\circ} \mathrm{C}$ & GC-MS & No & $\begin{array}{l}\text { Half-life (days): } 4.6 \\
\text { (alkanes with } \\
\text { dispersant); } 9.9 \\
\text { alkanes (without } \\
\text { dispersant) }\end{array}$ \\
\hline $\begin{array}{l}\text { Medina-Bellver et } \\
\text { al. } 2005\end{array}$ & $\begin{array}{l}\text { Heavy hydrocarbon } \\
\text { fractions (samples } \\
\text { from Prestige) }\end{array}$ & & $\begin{array}{l}\text { Contaminated samples } \\
\text { collected from the } \\
\text { shore and microcosm } \\
\text { with biostimulation }\end{array}$ & Water & $\begin{array}{l}\text { Seawater and contaminated } \\
\text { shore samples: Isle of Ons (Spain) }\end{array}$ & $\begin{array}{r}1 \text { month } \\
\text { (microcosm } \\
\text { study) }\end{array}$ & $\begin{array}{r}20^{\circ} \mathrm{C} \text { (microcosm } \\
\text { study) }\end{array}$ & $\begin{array}{l}\mathrm{DIC} \text { to } \mathrm{CO}_{2} \\
\text { transformation }\end{array}$ & MPN & $\begin{array}{l}\text { Microcosm studies: - } \\
10(\text { Evolution of DIC } \\
\left.\delta_{13} \mathrm{C}\right)\end{array}$ \\
\hline Mcfarlin et al. 2014 & $\begin{array}{l}\text { Medium hydrocarbon } \\
\text { fraction (Alaska North } \\
\text { Slope crude oil) }\end{array}$ & 2,200 & Mesocosm & Water & Seawater: Chukchi Sea (USA) & 6od & $-1^{\circ} \mathrm{C}$ & GC-MS & $\begin{array}{l}\text { (Respirometer for } \\
\mathrm{CO}_{2} \text { measurement) }\end{array}$ & 46-61\% (Total GC) \\
\hline $\begin{array}{l}\text { Kristenesen et al. } \\
2015\end{array}$ & $\begin{array}{l}\text { Light fuel Oil (North } \\
\text { Sea crude oil) }\end{array}$ & 100,000 & Microcosm & Water & $\begin{array}{l}\text { Seawater: Hirtshals Harbour, } \\
\text { Denmark, and Disko Bay } \\
\text { (Greenland) }\end{array}$ & $71 \mathrm{~d}$ & $15^{\circ} \mathrm{C}$ and $5^{\circ} \mathrm{C}$ & GC-MS & MPN & $\begin{array}{l}0.1-75.0 \%(\mathrm{nC} 8- \\
\mathrm{nC} 14), 90.4-104.5 \% \\
\text { (above nC-14) }\end{array}$ \\
\hline
\end{tabular}




\begin{tabular}{|c|c|c|c|c|c|c|c|c|c|c|}
\hline Crisafiet al. 2016 & $\begin{array}{l}\text { Light fuel oil (Arabian } \\
\text { light crude oil) }\end{array}$ & 500 & Microcosm & Water & $\begin{array}{l}\text { Seawater: Kongsfjorden, } \\
\text { Svalbard (Norway) }\end{array}$ & 6od & $4^{\circ} \mathrm{C} \& 15^{\circ} \mathrm{C}$ & GC-FID & $\begin{array}{l}\text { MPN, DAPI counting, } \\
\text { 16S rDNA sequencing }\end{array}$ & $\begin{array}{l}79 \%(4 \mathrm{C}), 87 \%(15 \mathrm{C}) \\
\text { (total extracted and } \\
\text { resolved } \\
\text { hydrocarbons } \\
(\mathrm{TERHC}) \text { ) }\end{array}$ \\
\hline Lin et al. 2009 & $\begin{array}{l}\text { Mixed oil and vacuum } \\
\text { oil }\end{array}$ & 2,000 & Microcosm & Water & $\begin{array}{l}\text { Strain: Pseudoalteromonas sp. } \\
\mathrm{P}_{29} \text { isolated from arctic sediment } \\
\text { (Arctic Ocean) }\end{array}$ & $28 \mathrm{~d}$ & $5^{\circ} \mathrm{C}$ & GC-MS & $\begin{array}{l}\text { Quick test API } 20 \mathrm{NE} \\
\text { system (BioMerieux) }\end{array}$ & $\begin{array}{l}\text { ca. } 90 \% \text { (mixed oil), } \\
\text { c. } 80 \% \text { (vacuum oil) }\end{array}$ \\
\hline $\begin{array}{l}\text { Brakstad and } \\
\text { Bonaunet } 2006\end{array}$ & $\begin{array}{l}\text { Light fuel oil (crude oil } \\
\text { Statfjord) }\end{array}$ & 1,000 & $\begin{array}{l}\text { Microcosm, } \\
\text { biodegradation of oil } \\
\text { immobilised in } \\
\text { Fluortex adsorbents }\end{array}$ & Water & $\begin{array}{l}\text { Seawater: Trondheimsfjord } \\
\text { (Norway) }\end{array}$ & $56 \mathrm{~d}$ & o and $5^{\circ} \mathrm{C}$ & GC-MS, GC-FID & $\begin{array}{l}\text { DAPI, FISH, DGGE, } \\
\text { RFLP, } 16 \mathrm{~S} \\
\text { sequencing, } 14 \mathrm{C}- \\
\text { labelled }\end{array}$ & $\begin{array}{l}61-100 \%\left(5^{\circ} \mathrm{C} \text {, all }\right. \\
\text { measured compounds) } \\
\text { and } 31.65 \text { to } 89.5 \% \text { (o } \\
{ }^{\circ} \mathrm{C} \text {, all measured } \\
\text { compounds) }\end{array}$ \\
\hline Deppe et al. 2004 & $\begin{array}{l}\text { Light fuel oils (North } \\
\text { Sea crude oils) }\end{array}$ & 20,000 & Microcosm & Water & $\begin{array}{l}\text { Seawater: Spitzbergen, Svalbard } \\
\text { (Norway) }\end{array}$ & 6 weeks & $4^{\circ} \mathrm{C}$ & GC-FID, GC-MS & $\begin{array}{l}16 \mathrm{~S} \text { rDNA } \\
\text { sequencing, DGGE }\end{array}$ & $65 \%$ (after 5 weeks) \\
\hline Hazen et al. 2010 & $\begin{array}{l}\text { Light fuel oils (light } \\
\text { crude (API35), } \\
\text { Macondo oil (MC252 } \\
\text { block)) }\end{array}$ & 100,000 & Microcosm & Water & $\begin{array}{l}\text { Seawater: Gulf of Mexico } \\
\text { (Mexico) }\end{array}$ & $20 \mathrm{~d}$ & $5^{\circ} \mathrm{C}$ & $\begin{array}{l}\text { GC-FID, GC-MS, SR- } \\
\text { FTIR }\end{array}$ & $\begin{array}{l}\text { PhyloChip 16S } \\
\text { ribosomal RNA } \\
\text { microarray, 16S } \\
\text { rRNA gene } \\
\text { sequencing }\end{array}$ & $\begin{array}{l}\text { Half-life (days): 1.2-6.1 } \\
\text { alkanes in situ change; } \\
2.2-3.5 \text { alkanes } \\
\text { microcosm, enriched } \\
\text { consortia }\end{array}$ \\
\hline Reunamo et al. 2013 & Diesel & $2,000,000$ & Microcosm & Water & $\begin{array}{l}\text { Seawater: Askainen, Raisio, } \\
\text { Pansio (Finland) }\end{array}$ & $22 \mathrm{~d}$ & $15^{\circ} \mathrm{C}$ & GC-FID & $\begin{array}{l}\text { T-RFLP, qPCR, } \\
\text { sequencing }\end{array}$ & $7-40 \%\left(C_{10}-C_{4} 0\right)$ \\
\hline Scheibye et al. 2017 & $\begin{array}{l}\text { Light petroleum } \\
\text { compounds (light } \\
\text { crude oil from } \\
\text { Draugen) }\end{array}$ & 10,000 & Microcosm & Water & Seawater: Disco Bay (Greenland) & $71 \mathrm{~d}$ & $2^{\circ} \mathrm{C}$ & GC-MS, GC-FID & No & $18 \%(\mathrm{TPH})$ \\
\hline Brakstad et al. 2015 & Macondo (MASS) oil & 2,000 & $\begin{array}{l}\text { Microcosm/oil droplet } \\
\text { generator (with } \\
\text { dispersant) }\end{array}$ & Water & Seawater: Trondheim (Norway) & $64 \mathrm{~d}$ & $5^{\circ} \mathrm{C}$ & GC-MS, GC-FID & $\begin{array}{l}\text { Cell counting } \\
\text { (Unpublished article) }\end{array}$ & $\begin{array}{l}40.1 \% \text { (reduction of } \\
\text { TEOC) }\end{array}$ \\
\hline Prince et al. 2016 & $\begin{array}{l}\text { Medium fuel oil } \\
\text { (European crude oil) }\end{array}$ & 2,5 & $\begin{array}{l}\text { Microcosm at high } \\
\text { pressure (15 Mpa) with } \\
\text { dispersant (Corexit } \\
9500)\end{array}$ & Water & Seawater: Logy Bay (Canada) & $35 \mathrm{~d}$ & $5^{\circ} \mathrm{C}$ & GC/MS & No & $\begin{array}{l}81 \% \text { (detectable } \\
\text { hydrocarbons, } 0.1 \\
\text { Mpa), } 71 \% \text { (detectable } \\
\text { hydrocarbons, } 15 \mathrm{Mpa} \text { ) }\end{array}$ \\
\hline Prince et al. 2013 & $\begin{array}{l}\text { Medium fuel Oil } \\
\text { (Alaska North Slope } \\
\text { crude oil) }\end{array}$ & 2,3 & Microcosm & Water & $\begin{array}{l}\text { Seawater: New Jersey shore } \\
\text { (USA) }\end{array}$ & 6od & $8^{\circ} \mathrm{C}$ & GC/MS & No & $\begin{array}{l}82 \% \text { (detectable } \\
\text { hydrocarbons), } 88 \% \\
\text { (detectable } \\
\text { hydrocarbons, Corexit } \\
9500 \text { ) }\end{array}$ \\
\hline Kadali et al. 2013 & $\begin{array}{l}\text { Medium fuel oil (crude } \\
\text { oil) }\end{array}$ & $10,000,000$ & Mesocosms & Water & $\begin{array}{l}\text { No information on seawater } \\
\text { source }\end{array}$ & $28 \mathrm{~d}$ & $22-25^{\circ} \mathrm{C}$ & GC-FID & $\begin{array}{l}\text { TGGE, } \mathrm{CO}_{2-} \\
\text { measurements }\end{array}$ & $\begin{array}{l}28 \% \text { (TPH, with } \\
\text { microbial consortia), } \\
16 \%(\text { TPH, no } \\
\text { microbial consortia) }\end{array}$ \\
\hline Delille et al. 2009 & $\begin{array}{l}\text { Light and medium fuel } \\
\text { oils (diesel and crude } \\
\text { oil) }\end{array}$ & 5,000 & Microcosm & Water & $\begin{array}{l}\text { Seawater: Morbihan Bay } \\
\text { (Kerguelen Archipelago) }\end{array}$ & $51 \mathrm{~d}$ & 4,10 and $20^{\circ} \mathrm{C}$. & GC-MS & $\begin{array}{l}\text { Acridine orange } \\
\text { direct counts }\end{array}$ & $\begin{array}{l}\text { At } 10^{\circ} \mathrm{C}: \text { ca. } 64.5 \% \\
\text { (Crude oil, total } \\
\text { hydrocarbons), at } 4 \\
{ }^{\circ} \mathrm{C}: \text { ca. } 52 \% \text { (Crude oil, } \\
\text { total hydrocarbons) }\end{array}$ \\
\hline
\end{tabular}


Table 13: Biodegradation studies related to sediment compartment

\begin{tabular}{|c|c|c|c|c|c|c|c|c|c|c|}
\hline \multirow[b]{2}{*}{ Study name } & \multirow[b]{2}{*}{ Oil type } & \multirow[b]{2}{*}{$\begin{array}{l}\text { Initial oil } \\
\text { concentration } \\
(\mathrm{mg} / \mathrm{kg} \mathrm{dw})\end{array}$} & \multicolumn{7}{|c|}{ Biodegradation studies on sediment } & \multirow[b]{2}{*}{$\begin{array}{l}\text { Biodegradation rate or } \\
\text { percentage }\end{array}$} \\
\hline & & & Experiment type & Compartment & $\begin{array}{l}\text { Sample type and } \\
\text { location }\end{array}$ & Study time & Temperature & $\begin{array}{l}\text { Oil detection } \\
\text { method }\end{array}$ & $\begin{array}{l}\text { Molecular } \\
\text { biology } \\
\text { methods }\end{array}$ & \\
\hline $\begin{array}{l}\text { Garrett et al. } \\
2003\end{array}$ & $\begin{array}{l}\text { Heavy fuel oil } \\
\text { (IFO-30 } \\
\text { (sediment study) } \\
\text { and artificially } \\
\text { weathered } \\
\text { Alaska North } \\
\text { Slope oil } \\
\text { (seawater } \\
\text { study)) }\end{array}$ & 9,350 & Microcosm & $\begin{array}{l}\text { Sediment and } \\
\text { seawater }\end{array}$ & $\begin{array}{l}\text { Sediment: } \\
\text { Spitzenberger, } \\
\text { Svalbard (Norway), } \\
\text { Seawater: Prince } \\
\text { William Sound, } \\
\text { Alaska (USA) }\end{array}$ & $\begin{array}{l}\text { Over } 3 \text { months } \\
\text { (sediment } \\
\text { study) and go } \\
\text { days (seawater } \\
\text { study) }\end{array}$ & $\begin{array}{l}\text { Room } \\
\text { temperature } \\
\text { (sediment), } 6^{\circ} \mathrm{C} \\
\text { and } 20^{\circ} \mathrm{C} \\
\text { (seawater study) }\end{array}$ & GC-MS & No & $\begin{array}{l}\text { Sediment study: }<50 \% \\
\text { (Total HC) } \\
\text { Seawater study: } 48 \%(6 \\
\left.{ }^{\circ} \mathrm{C}\right), 61.5 \%\left(20^{\circ} \mathrm{C}\right) \text { (Total } \\
\text { HC) }\end{array}$ \\
\hline Hua 2006 & $\begin{array}{l}\text { Heavy fuel oil } \\
\text { (Bunker C) }\end{array}$ & 93,500 & $\begin{array}{l}\text { Microcosms with } \\
\text { sediment (dispersant } \\
\text { and soapwater) }\end{array}$ & Sediment & $\begin{array}{l}\text { Sediment: Shen } \\
\text { Au, Taiwan. }\end{array}$ & $70 \mathrm{~d}$ & $\begin{array}{l}5,10,20 \text { and } 30 \\
{ }^{\circ} \mathrm{C} C\end{array}$ & $\begin{array}{l}\text { GC-FID, IR } \\
\text { spectoscopy }\end{array}$ & Plate counting & $\begin{array}{l}47 \% \text { (chemical } \\
\text { dispersant) and } 16 \% \\
\text { (soapwater) }\end{array}$ \\
\hline $\begin{array}{l}\text { Gallego et al. } \\
2006\end{array}$ & $\begin{array}{l}\text { Heavy fuel oil } \\
\text { (Prestige } \\
\text { sediment } \\
\text { sample) }\end{array}$ & $\begin{array}{l}\text { Polluted sediment, } \\
\text { initial } \\
\text { concentration not } \\
\text { reported }\end{array}$ & $\begin{array}{l}\text { On-site biostimulation } \\
(\mathrm{S}-200)\end{array}$ & Sediment & $\begin{array}{l}\text { Oil sample: Costa } \\
\text { de la Muerte, La } \\
\text { Coruna (Spain) }\end{array}$ & 2 years & Variable & GC-MS & Plate counting & $\begin{array}{l}\text { ca. } 35 \% \text { (aromatics, } \\
\text { compared to hopane), } \\
100 \% \text { (light-medium } \\
\text { linear alkanes, compared } \\
\text { to hopane) }\end{array}$ \\
\hline $\begin{array}{l}\text { Fernandes- } \\
\text { Alvares et al. } \\
2006\end{array}$ & $\begin{array}{l}\text { Heavy fuel oil } \\
\text { (Prestige } \\
\text { sediment } \\
\text { sample) }\end{array}$ & $\begin{array}{l}\text { Polluted sediment, } \\
\text { initial } \\
\text { concentration not } \\
\text { reported }\end{array}$ & $\begin{array}{l}\text { On-site biostimulation } \\
\text { (Nitrophoska, } \\
\text { Biodiesel) and } \\
\text { bioaugmentation } \\
\text { (L180o \& B350) }\end{array}$ & Sediment/beach & $\begin{array}{l}\text { Sorrizo,A Coruna } \\
\text { (Spain) }\end{array}$ & $240 \mathrm{~d}$ & Variable & GC-MS & Plate counting & $\begin{array}{l}\text { ca. } 80 \% \text { (PAH } \\
\text { degradation, hopane } \\
\text { normalised) }\end{array}$ \\
\hline $\begin{array}{l}\text { Jimenez et al. } \\
2007\end{array}$ & $\begin{array}{l}\text { Heavy fuel oil } \\
\text { (Prestige } \\
\text { sediment } \\
\text { sample) }\end{array}$ & $\begin{array}{l}\text { Polluted sediment, } \\
\text { initial } \\
\text { concentration not } \\
\text { reported }\end{array}$ & $\begin{array}{l}\text { Field bioremediation } \\
\text { assay }\end{array}$ & Sediment (Beach) & $\begin{array}{l}\text { In situ location: } \\
\text { Virgen del Mar, } \\
\text { Santander (Spain) }\end{array}$ & $220 \mathrm{~d}$ & $3.8^{\circ} \mathrm{C}$ to $22.5^{\circ} \mathrm{C}$ & GC-MS & $\begin{array}{l}\text { DGGE, } \\
\text { sequencing }\end{array}$ & $\begin{array}{l}38-96 \% \text { (range of } \\
\text { fractions } \mathrm{C}_{22}-\mathrm{C}_{35} \text {, } \\
\text { compared to } \mathrm{h} \\
17 \alpha(\mathrm{H}), 21 \beta-(\mathrm{H}) \text {-hopane) }\end{array}$ \\
\hline $\begin{array}{l}\text { Genovese et al. } \\
2014\end{array}$ & $\begin{array}{l}\text { Heavy fuel oil } \\
\text { (Bunker C) }\end{array}$ & 6,273 & Mesocosm & Sediment & $\begin{array}{l}\text { Seawater: Harbour } \\
\text { of Messina (Italy) }\end{array}$ & 3 months & $20^{\circ} \mathrm{C}$ & $\begin{array}{l}\text { dichloromethane- } \\
\text { acetone, GC-FID }\end{array}$ & $\begin{array}{l}\text { CARD-FISH, } \\
\text { pPCR, 16sDNA } \\
\text { sequencing }\end{array}$ & $\begin{array}{l}\text { 18.2\% (TERHC without } \\
\text { aeration), } 97.7 \% \text { (TERHC } \\
\text { fraction, with aeration) }\end{array}$ \\
\hline $\begin{array}{l}\text { Reunamo et al. } \\
2017\end{array}$ & $\begin{array}{l}\text { Medium crude } \\
\text { oil (Russian } \\
\text { crude oil) }\end{array}$ & 500 & Microcosm & $\begin{array}{l}\text { Sediment and } \\
\text { concretions }\end{array}$ & $\begin{array}{l}\text { Sediment and } \\
\text { concretions: } \\
\text { Various sites in the } \\
\text { Baltic Sea }\end{array}$ & $\begin{array}{l}\text { Experiment 1: } \\
17 \text { weeks, } \\
\text { Experiment 2: } \\
11 \text { weeks }\end{array}$ & $10^{\circ} \mathrm{C}$ & GC-FID & $\begin{array}{l}\text { DGGE, qPCR, } \\
16 \mathrm{SNA} \\
\text { sequencing }\end{array}$ & $\begin{array}{l}\text { Experiment 1: 51-59\% } \\
\text { (Anoxic). Experiment 2: } \\
\text { Concretions: } 35-80 \% \text {, all } \\
\text { results } \mathrm{C}_{10}-\mathrm{C}_{4} \mathrm{O} . \text { oxic: } 1 \text { - } \\
18 \mathrm{mg} \mathrm{kg}-1 \mathrm{~d}-1 \text { anoxic: } 1 \text { - } \\
9 \mathrm{mg} \mathrm{kg}-1 \mathrm{~d}-1\end{array}$ \\
\hline $\begin{array}{l}\text { Sharma \& } \\
\text { Schiewer } 2016\end{array}$ & $\begin{array}{l}\text { Light fuel oil } \\
\text { (North Slope } \\
\text { Crude) }\end{array}$ & 4,350 & Microcosm & Sediment and water & $\begin{array}{l}\text { Sediment: Barrow } \\
\text { (Alaska) }\end{array}$ & 6 weeks & $3^{\circ} \mathrm{C}$ and $20^{\circ} \mathrm{C}$ & GC-MS, GC-FID & No & $\begin{array}{l}\text { ca. } 46 \% \text { at } 3^{\circ} \mathrm{C} \text { (salinity } \\
30 \mathrm{~g} / \mathrm{L})(2600 \mathrm{mg} / \mathrm{kg})\end{array}$ \\
\hline
\end{tabular}


Table 14: Biodegradation studies related to soil compartment

\begin{tabular}{|c|c|c|c|c|c|c|c|c|c|c|}
\hline \multirow[b]{2}{*}{$\begin{array}{l}\text { Study } \\
\text { name }\end{array}$} & \multirow[b]{2}{*}{ Oil type } & \multirow[b]{2}{*}{$\begin{array}{r}\text { Initial } \\
\text { concentratio } \\
\mathrm{n}(\mathrm{mg} / \mathrm{kg} \mathrm{dw})\end{array}$} & \multicolumn{7}{|c|}{ Biodegradation studies on soil } & \multirow[b]{2}{*}{$\begin{array}{l}\text { Biodegradation rate or } \\
\text { percentage }\end{array}$} \\
\hline & & & Experiment type & $\begin{array}{l}\text { Compart- } \\
\text { ment }\end{array}$ & Sample type and location & $\begin{array}{l}\text { Study } \\
\text { time }\end{array}$ & Tempeture & $\begin{array}{l}\text { Oil detection } \\
\text { method }\end{array}$ & $\begin{array}{l}\text { Molecular biology } \\
\text { methods }\end{array}$ & \\
\hline $\begin{array}{l}\text { Wang et al. } \\
2016\end{array}$ & Crude oil & 10,600 & $\begin{array}{l}\text { Microscosm, soil } \\
\text { biodegradation }\end{array}$ & Soil & $\begin{array}{l}\text { Sludge: Dalian Petrochemical } \\
\text { Co. (China) }\end{array}$ & $150 \mathrm{~d}$ & $10^{\circ} \mathrm{C}$ & $\begin{array}{l}\text { ESI FT ICR MS, GC- } \\
\text { MS }\end{array}$ & 16S rDNA sequencing & $61-78 \%$ \\
\hline $\begin{array}{l}\text { Cai et al. } \\
2016\end{array}$ & $\begin{array}{l}\text { Venezuelan } \\
\text { heavy crude oil }\end{array}$ & 12,100 & $\begin{array}{l}\text { Microcosm, } \\
\text { bioaugmentation }\end{array}$ & Soil & $\begin{array}{l}\text { Soil and strains for } \\
\text { bioaugmentation: Xingang } \\
\text { port, Dalian city (China) }\end{array}$ & god & $17-29^{\circ} \mathrm{C}$ & GC-MS & $\begin{array}{l}\text { Cell counting, } 16 \mathrm{~S} \text { rRNA } \\
\text { sequencing }\end{array}$ & $\begin{array}{l}20.7 \% \text { (TPH, natural } \\
\text { attenuation), } 54.6 \% \text { (TPH, } \\
\text { bioaugmentation) }\end{array}$ \\
\hline $\begin{array}{l}\text { Björklöf et } \\
\text { al. } 2008\end{array}$ & $\begin{array}{l}\text { Aged and } \\
\text { weathered waste } \\
\text { oil }\end{array}$ & 14,900 & Mesocosms & Subsoil & $\begin{array}{l}\text { Soil: Coastal former waste site } \\
\text { Trollberget, Hanko, Finland }\end{array}$ & $\begin{array}{l}120 d \\
\text { (oxic) } \\
330 d \\
\text { (anoxic) }\end{array}$ & $7^{\circ} \mathrm{C}$ & GC-FID & $\mathrm{CO}_{2}$ and $\mathrm{CH}_{4}$ production & $\begin{array}{l}\text { oxic: } 2-34 \mathrm{mg} \mathrm{THP} \mathrm{kg}^{-1} \mathrm{~d}^{-1} \\
\text { anoxic: } 1-12 \mathrm{mg} \mathrm{TPH} \mathrm{kg}^{-1} \mathrm{~d}^{-1}\end{array}$ \\
\hline $\begin{array}{l}\text { Salminen } \\
\text { et al. } 2004\end{array}$ & $\begin{array}{l}\text { Aged and } \\
\text { weathered waste } \\
\text { oil }\end{array}$ & 68,600 & Microcosms & Subsoil & $\begin{array}{l}\text { Soil: Coastal former waste site } \\
\text { Trollberget, Hanko, Finland }\end{array}$ & $\begin{array}{l}120 d \\
\text { (oxic) } \\
360 d \\
\text { (anoxic) }\end{array}$ & $8^{\circ} \mathrm{C}$ & GC-FID & $\begin{array}{l}\mathrm{CO}_{2} \text { and } \mathrm{CH}_{4} \\
\text { production }\end{array}$ & $\begin{array}{l}\text { oxic: } 31 \% \\
\text { anoxic: } 44 \%\end{array}$ \\
\hline $\begin{array}{l}\text { Delille \& } \\
\text { Coulon } \\
2008\end{array}$ & $\begin{array}{l}\text { Light/medium } \\
\text { fuel (Arabian } \\
\text { light crude oil, } \\
\text { diesel) }\end{array}$ & 300,000 & $\begin{array}{l}\text { Mesocosm/Biore } \\
\text { mediation (Inipol) }\end{array}$ & Soil & $\begin{array}{l}\text { Soil: Near Port aux Français } \\
\text { Scientific station in } \\
\text { Kerguelen Archipelago }\end{array}$ & $42 \mathrm{~d}$ & $\begin{array}{l}4^{\circ} \mathrm{C}, 10^{\circ} \mathrm{C} \\
\text { and } 20^{\circ} \mathrm{C}\end{array}$ & GC-MS & Microbial enumeration & $70-76 \%$ (TERHC, at 4C) \\
\hline $\begin{array}{l}\text { Coulon et } \\
\text { al. } 2004\end{array}$ & $\begin{array}{l}\text { Light and } \\
\text { medium fuels } \\
\text { (Arabian light } \\
\text { crude oil, diesel) }\end{array}$ & 891 & $\begin{array}{l}\text { Field } \\
\text { study/Bioremedia } \\
\text { tion (Inipol) }\end{array}$ & Soil & $\begin{array}{l}\text { Soil: Near Port aux Français } \\
\text { Scientific station in } \\
\text { Kerguelen Archipelago }\end{array}$ & $660 \mathrm{~d}$ & $0^{\circ} \mathrm{C}$ to $20^{\circ} \mathrm{C}$ & GC-MS & Microbial enumeration & $\begin{array}{l}\text { (TPH) loss }>80 \% \text { (diesel and } \\
\text { crude oil) }\end{array}$ \\
\hline $\begin{array}{l}\text { Margesin } \\
\text { et al. } 1997\end{array}$ & $\begin{array}{l}\text { Light fuel oils } \\
\text { (diese) }\end{array}$ & 4,000 & $\begin{array}{l}\text { Mesocosm, } \\
\text { fertilizers }\end{array}$ & Soil & Soil: Tyrolean Alps (Austria) & $155 \mathrm{~d}$ & $10^{\circ} \mathrm{C}$ & $\begin{array}{l}\text { infrared } \\
\text { spectrometer, } \\
\text { dehydrogenase }\end{array}$ & MPN & $<95 \%$ (Total hydrocarbons) \\
\hline
\end{tabular}


Table 15: Biodegradation studies related to sea-ice compartment

\begin{tabular}{|c|c|c|c|c|c|c|c|c|c|c|}
\hline \multicolumn{11}{|c|}{ Biodegradation studies on sea-ice } \\
\hline Study name & Oil type & Concentration & Experiment type & $\begin{array}{l}\text { Compart- } \\
\text { ment }\end{array}$ & $\begin{array}{l}\text { Sample type and } \\
\text { location }\end{array}$ & Study time & Temperature & $\begin{array}{l}\text { Oil detection } \\
\text { method }\end{array}$ & $\begin{array}{l}\text { Molecular } \\
\text { biology methods }\end{array}$ & $\begin{array}{l}\text { Biodegradation rate or } \\
\text { percentage }\end{array}$ \\
\hline $\begin{array}{l}\text { Gerdes et al. } 2005 \\
\text { (manuscript 1) }\end{array}$ & $\begin{array}{l}\text { Medium fuel oil (Crude } \\
\text { oil) }\end{array}$ & $\begin{array}{l}500 \mu \mathrm{l} \text { of crude } \\
\text { oil per } 25 \mathrm{ml} \text { sea- } \\
\text { ice, } 20 \mu \mathrm{l} \text { in pure } \\
\text { culture studies }\end{array}$ & $\begin{array}{l}\text { Microcosms + pure } \\
\text { culture study on the } \\
\text { isolates }\end{array}$ & Sea ice & $\begin{array}{l}\text { Seawater (ice cores): } \\
\text { Svalbard (Norway) }\end{array}$ & $\begin{array}{l}1 \text { year, } 29 \text { days for } \\
\text { the pure culture } \\
\text { study }\end{array}$ & $1^{\circ} \mathrm{C}$ & None & $\begin{array}{l}\text { FISH, DGGE, } \\
\text { isolations }\end{array}$ & $\begin{array}{l}\text { Pure culture studies: } 1.7-5.4 \% \\
\text { ([14C]hexadecane, measured } \\
\text { as }[14 \mathrm{C}] \mathrm{CO}_{2} \text { production) }\end{array}$ \\
\hline $\begin{array}{l}\text { Gerdes } 2006 \\
\text { (Doctoral thesis) }\end{array}$ & $\begin{array}{l}\text { Medium fuel oil } \\
\text { (Southern Barents Sea } \\
\text { crude oil) }\end{array}$ & & $\begin{array}{l}\text { Mesocosm study, } \\
\text { biostimulation (Inipol, } \\
\text { fish meal) }\end{array}$ & Sea ice & $\begin{array}{l}\text { Arctic and Antarctic } \\
\text { ice-cores }\end{array}$ & Over 2 years & $-3^{\circ} \mathrm{C}$ & GC-FID & $\begin{array}{l}\text { DGGE, FISH, } \\
\text { hydrocarbon } \\
\text { degradation } \\
\text { determined by } \\
\mathrm{CO}_{2} \text {-formation } \\
\text { (infrared) }\end{array}$ & $\begin{array}{l}\text { Only qualitative estimations } \\
\text { of degradation rates }\end{array}$ \\
\hline $\begin{array}{l}\text { Helmke et al. } \\
2008\end{array}$ & $\begin{array}{l}\text { Medium fuel oil (crude } \\
\text { oil) }\end{array}$ & & $\begin{array}{l}\text { Mesocosm study, } \\
\text { biostimulation (Inipol, } \\
\text { fish meal) }\end{array}$ & Sea ice & $\begin{array}{l}\text { Spitsenbergen } \\
\text { (Norway), } \\
\text { Bellingshausen sea } \\
\text { (Antarctic) }\end{array}$ & Over 36 months & $\begin{array}{l}-3^{\circ} \mathrm{C} \text { (sea-ice) and } \\
+4^{\circ} \mathrm{C} \text { (melted ice) }\end{array}$ & Not specified & ARDRA & $\begin{array}{l}\text { Biodegradation described } \\
\text { qualitatively, results between } \\
\text { completely degraded and not } \\
\text { degraded }\end{array}$ \\
\hline $\begin{array}{l}\text { Gerdes et al. } 2006 \\
\text { (manuscript 2) }\end{array}$ & $\begin{array}{l}\text { Light fuel oil (Statfjord } \\
\text { crude oil) }\end{array}$ & $\begin{array}{l}1 \mathrm{ml} / \mathrm{l}, 1000 \mathrm{ppm}, \\
\text { in } 1800 \mathrm{ml} \\
\text { crushed sea-ice } \\
\text { or } 800 \mathrm{ml} \text { gap } \\
\text { water }\end{array}$ & $\begin{array}{l}\text { Field and microcosm } \\
\text { studies, } \\
\text { biostimulation (fish } \\
\text { meal, Inipol) }\end{array}$ & Sea ice & $\begin{array}{l}\text { Sea-ice and gap- } \\
\text { water: Antarctica }\end{array}$ & $\begin{array}{l}\text { first } 30 \text { d in the } \\
\text { field, then } 6 \\
\text { months (gap } \\
\text { water) and } 7 \\
\text { months (sea-ice) }\end{array}$ & $\begin{array}{l}\text { Sea-ice }-3^{\circ} \mathrm{C} \text {, gap } \\
\text { water } 0^{\circ} \mathrm{C}\end{array}$ & GC-FID, GC-MS & DGGE, FISH & $\begin{array}{l}\text { Pristane/phytane ratios: 1.09- } \\
1.15 \text { (biostimulated), 1.00- } \\
1.09 \text { (biostimulated \& } \\
\text { bioaugmented), } 1.18 \text { (sterile } \\
\text { control) }\end{array}$ \\
\hline $\begin{array}{l}\text { Gerdes et al. } 2006 \\
\text { (manuscript 3) }\end{array}$ & $\begin{array}{l}\text { Light fuel oil } \\
\text { (Microcosm: } \\
\text { weathered and non- } \\
\text { weathered crude oil } \\
\text { from the Barents Sea, } \\
\text { pure cultures: } \\
\text { Statfjord crude oil) }\end{array}$ & $0.2 \% \mathrm{vol} / \mathrm{vol}$, & Microcosm & Sea ice & $\begin{array}{l}\text { Ice cores from } \\
\text { Svalbard (Norway) and } \\
\text { Bellinghausen Sea } \\
\text { (Antarctic). }\end{array}$ & 95 days & $-3^{\circ} \mathrm{C}, 0^{\circ} \mathrm{C}$ or $4^{\circ} \mathrm{C}$ & GC-FID & ARDRA, ESEM & $\begin{array}{l}\text { Biodegradation rate described } \\
\text { qualitatively, results between } \\
\text { completely degraded and not } \\
\text { degraded }\end{array}$ \\
\hline $\begin{array}{l}\text { Gerdes et al. } 2006 \\
\text { (manuscript 4) }\end{array}$ & $\begin{array}{l}\text { Light fuel oil (crude oil } \\
\text { (Starfjord) } \\
\text { (microcosm)) }\end{array}$ & $\begin{array}{l}150 \mathrm{ml} \text { per tile } \\
(65 \times 45 \mathrm{~cm})\end{array}$ & $\begin{array}{l}\text { Field bioremediation } \\
\text { study, biostimulation } \\
\text { (fish meal, Inipol) }\end{array}$ & Sea ice & $\begin{array}{l}\text { Field study: Van Mijen } \\
\text { Fjord, Svalbard } \\
\text { (Norway) }\end{array}$ & 3 months & $\begin{array}{l}\text { February-April } \\
2004, \\
-30^{\circ} \mathrm{C} \text { to }-10^{\circ} \mathrm{C}, \\
\text { last two weeks - } \\
7^{\circ} \mathrm{C} \text { to } \\
0^{\circ} \mathrm{C}\end{array}$ & GC-FID & $\begin{array}{l}\text { DGGE, FISH, total } \\
\text { counts }\end{array}$ & $\begin{array}{l}\text { No significant microbial } \\
\text { biodegradation observed } \\
\text { during the incubation period }\end{array}$ \\
\hline $\begin{array}{l}\text { Brakstad et al. } \\
2008\end{array}$ & $\begin{array}{l}\text { Light fuel oil (Statfjord } \\
\text { crude oil) }\end{array}$ & $\begin{array}{l}30 \mathrm{~g} \text { oil per } 12,5 \\
\mathrm{~cm} ø \text { hole in the } \\
\text { ice }\end{array}$ & Field study & Sea ice & $\begin{array}{l}\text { Seawater: Van Mijen } \\
\text { Fjord (Norway) }\end{array}$ & $112 \mathrm{~d}$ & $-3^{\circ} \mathrm{C}$ to $-12{ }^{\circ} \mathrm{C}$ & GC-MS, GC-FID & $\begin{array}{l}\text { Plate-counting, } \\
\text { DGGE, RFLP }\end{array}$ & $\begin{array}{l}\text { Degradation (calculated from } \\
\text { figure, measured as } \\
\text { normalised nC17/pristane): o- } \\
6 \mathrm{~cm} \text { : ca. } 10.4 \%, 7-37 \mathrm{~cm} \text { : ca. } \\
10.4 \%, 38-43 \mathrm{~cm}: \mathrm{ca} .26 .6 \% \text {, } \\
44-64 \mathrm{~cm}: \mathrm{ca} .7 .9 \%\end{array}$ \\
\hline $\begin{array}{l}\text { Garneau et al. } \\
2016\end{array}$ & $\begin{array}{l}\text { Light fuel oil (Arabian } \\
\text { Light oil) }\end{array}$ & $25 \mathrm{mg} \mathrm{L}^{-1}$ & Microcosm & $\begin{array}{l}\text { Sea ice and } \\
\text { sub-ice } \\
\text { water }\end{array}$ & $\begin{array}{l}\text { Resolute Passage } \\
\text { (Canada) }\end{array}$ & $15 \mathrm{~d}$ & $-1.7^{\circ} \mathrm{C}$ & GC-MS & $\begin{array}{l}\text { ARISA, 16S rRNA } \\
\text { gene sequencing, } \\
\text { flow cytometry }\end{array}$ & $\begin{array}{l}13 \% \text { (sea-ice microcosms), } \\
63 \% \text { (sub-ice seawater } \\
\text { microcosm) }\end{array}$ \\
\hline
\end{tabular}


Nordic Council of Ministers

Nordens Hus

Ved Stranden 18

DK-1061 Copenhagen

www.norden.org

\section{HEAVY FUEL OIL (HFO)}

Shipping activities across the Artic are expected to increase with decreasing sea ice cover, thus increasing the risk of oil spills. Heavy Fuel Oil (HFO, a mixture of residual fuel and distillate diluent) is often used as fuel in marine vessels as it is relatively cheaper than e.g. lighter marine fuels. Knowledge about fate and behaviour of HFOs is important to select the most efficient countermeasures in an oil spill situation as well as in the risk assessment of possible oil spills in cold waters. The aim of this review is to collate and strengthen the knowledge base on HFO in cold seawater, its fate and behaviour, including weathering, biodegradation, environmental implications of HFO spills and HFO spill response including environmental considerations regarding use the of chemical dispersants and in situ burning. Knowledge gaps and research needs are identified and described. 